
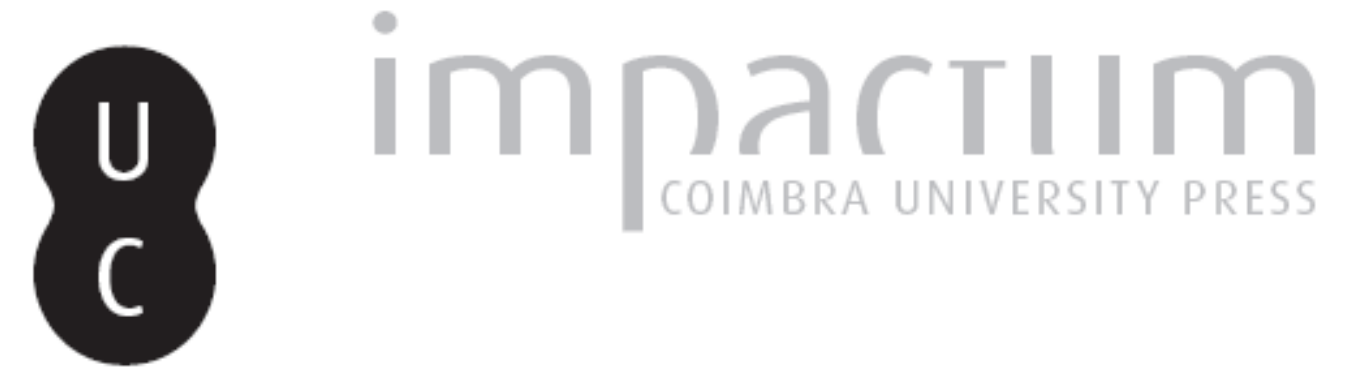

\title{
Aplicação de princípios perequativos em áreas de riscos naturais: um caso de estudo
}

\author{
Autor(es): $\quad$ Pereira, Pedro Matias
}

Publicado por: CEDOUA

URL persistente:

URl:http://hdl.handle.net/10316.2/8836

DOI: http://dx.doi.org/10.14195/2182-2387_22_4

Accessed : $\quad$ 26-Apr-2023 13:07:32

A navegação consulta e descarregamento dos títulos inseridos nas Bibliotecas Digitais UC Digitalis, UC Pombalina e UC Impactum, pressupõem a aceitação plena e sem reservas dos Termos e Condições de Uso destas Bibliotecas Digitais, disponíveis em https://digitalis.uc.pt/pt-pt/termos.

Conforme exposto nos referidos Termos e Condições de Uso, o descarregamento de títulos de acesso restrito requer uma licença válida de autorização devendo o utilizador aceder ao(s) documento(s) a partir de um endereço de IP da instituição detentora da supramencionada licença.

Ao utilizador é apenas permitido o descarregamento para uso pessoal, pelo que o emprego do(s) título(s) descarregado(s) para outro fim, designadamente comercial, carece de autorização do respetivo autor ou editor da obra.

Na medida em que todas as obras da UC Digitalis se encontram protegidas pelo Código do Direito de Autor e Direitos Conexos e demais legislação aplicável, toda a cópia, parcial ou total, deste documento, nos casos em que é legalmente admitida, deverá conter ou fazer-se acompanhar por este aviso.

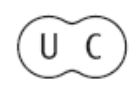





\section{Aplicação de Princípios Perequativos em Áreas de Riscos Naturais. Um Caso de Estudo}

\begin{abstract}
O planeamento de nível municipal exige a integração de mecanismos de perequação, que visam dotar as autoridades locais de métodos que lhes permitam levar a cabo as suas estratégias de desenvolvimento para o território sem lesar os proprietários com as desigualdades introduzidas pelo acto de planear. Dada a sua valia na busca de equidade, através da criação de sistemas de compensações mútuas, questiona-se da possibilidade de utilização da sua lógica de funcionamento na gestão e mitigação dos riscos naturais.

As linhas que se seguem visam fornecer alguns tópicos de reflexão a este propósito, as quais são feitas com base num caso de estudo, no âmbito do qual se testou a aplicação de mecanismos assentes numa lógica perequativa à gestão de riscos naturais ${ }^{1}$.
\end{abstract}

\section{Considerações introdutórias: a questão}

São cada vez mais visíveis as fragilidades do território e da sociedade em relação aos diversos tipos de perigos naturais, tornando premente a criação de instrumentos de prevenção e de mecanismos de resposta a estes processos, de modo a enfrentar, de forma eficaz, os desastres com causas naturais ou antropogénicas e a prevenir ou reduzir os seus impactes.

A análise do ris $\mathrm{CO}^{2}$, pressupõe um horizonte normativo relativo às questões de segurança e confiança, em que o quadro ético está implícito, mas onde o aparecimento de novas desigualdades sociais na exposição ao risco exige abordagens diferenciadas. Tendo em conta que uma das prioridades das sociedades modernas é a prevenção e a redução do perigo e o aumento da resiliência dos indivíduos e das comunidades para efectuar uma gestão eficaz dos riscos ${ }^{3}$, torna-se essencial a criação de políticas de valorização do território que os tenham em consideração. A integração das ciências do risco no planeamento territorial apresenta-se, para o efeito, como uma via incontornável: porque grande parte dos riscos

\footnotetext{
${ }^{1}$ O presente texto teve na sua base a Dissertação de Mestrado do primeiro autor deste artigo, apresentado na Faculdade de Ciências e Tecnologia da Universidade de Coimbra em 2008 intitulada Construção de critérios perequativos para áreas com riscos naturais. Aplicação ao sector sul de concelho de Coimbra, da qual o segundo e o terceiro autores foram, respectivamente, orientador e co-orientadora. As imagens inseridas nas p.65, 66, 110, 112, 113 a 115, 117 e 118 desta Revista podem ser consultadas a cores em http://www.cedoua.fd.uc.pt/.

2 BECK, Ulrich, La Société du Risque - Sur la voie d’une autre modernité, Champ Flammarion, Paris, 2001, p.521.

${ }^{3}$ MENDES, José e TAVARES, Alexandre, "Building resilience to natural hazards. Practices and policies on governance and mitigation in the central region of Portugal" in Safety, Reliability and Risk Analysis: Theory, Methods and Applications, Martorell et al. (eds). Taylor and Francis Group, London, 2009, pp. 1577-1584
} 
se referem a actividades - na medida em que algumas delas se revelam particularmente potenciadoras de riscos, naturais ou não - e a espaços - visto que alguns, como acontece com os leitos de cheia e o litoral, são particularmente susceptíveis ou vulneráveis a estes -, e porque os instrumentos de planeamento do território localizam actividades no espaço, não podem as decisões fundamentais a plasmar neles deixar de ser precedidas da avaliação da perigosidade e dos riscos inerentes.

A capacidade de reduzir os riscos está frequentemente dependente da alteração dos factores condicionantes da vulnerabilidade, assim como da forma como a administração e os cidadãos são confrontados com a necessidade de identificar nas suas comunidades os locais com maior perigo potencial, de forma a implementar programas de prevenção e mitigação do risco ou preparar planos de preparação do desastre ${ }^{5}$.

O conhecimento dos perigos e a redução e mitigação dos riscos devem, pois, ser assumidos (ao contrário do que tem sucedido nos últimos anos) como uma prioridade das políticas territoriais, designadamente, da política de ordenamento e de planeamento do território. ${ }^{6}$

É precisamente a propósito do planeamento territorial (em especial, do planeamento de nível municipal) - no âmbito do qual se procede à classificação e à qualificação dos solos -, que assumem particular relevo os mecanismos de perequação: instrumentos que visam dotar as autoridades locais de métodos que lhes permitam levar a cabo as suas estratégias de desenvolvimento para o território sem lesar os proprietários com as desigualdades introduzidas pelo acto de planear. A consagração destes mecanismos está prevista na legislação em vigor, sendo aplicada nos vários instrumentos de gestão territorial de eficácia plurisubjectiva.

Dada a sua valia na busca de equidade, através da criação de sistemas de compensações mútuas, questiona-se da possibilidade de utilização da sua lógica de funcionamento na gestão e mitigação dos riscos naturais.

As linhas que se seguem visam fornecer alguns tópicos de reflexão a este propósito, os quais não podem deixar, inevitavelmente, de levar a uma conclusão que antecipamos desde já: a de que a existência de um planeamento territorial que tenha em conta os perigos e os factores de risco presentes no território e que incorpore no seu interior medidas para a sua prevenção, redução e mitigação é uma necessidade premente e uma realidade incontornável.

As reflexões que aqui efectuamos têm na sua base um caso de estudo, no âmbito do qual se testou a aplicação de mecanismos assentes numa lógica perequeativa à gestão de riscos naturais.

\section{A perequação de benefícios e encargos}

\subsection{A perequação "urbanística" e a sua lógica}

Ocorreu em Portugal, nas últimas décadas, um forte crescimento urbano que levou à descaracterização do conceito tradicional de cidade e à ocupações, por vezes caóticas e muito pouco estruturadas, do território.

0 processo urbano esteve, durante anos, à mercê das múltiplas dinâmicas: económicas, financeiras, culturais, sociais, ideológicas e institucionais. Paralelamente, o quadro normati-

${ }^{4}$ FLAX, LK, JACKSON, RW, STEIN, DN, “Community vulnerability assessment tool methodology”. Nat Hazards Rev 3(4), 2002, pp.163-176.

${ }_{5}^{5}$ CRUZ, A.M. e OKADA, N., Methodology for preliminary assessment of Natech risk in urban areas, Nat. Hazards, 46, 2008, pp. 199-220

${ }^{6}$ Assiste-se, frequentemente, no contexto local, a falhas na implementação das políticas e práticas destinadas à gestão dos riscos, em resultado da dificuldade de aplicação de instrumentos e recursos numa lógica top-down ou do não reconhecimento dos riscos por parte dos diferentes actores intervenientes. Cfr. TAVARES, Alexandre e MENDES, José, "Risk prevention, risk reduction and planning policies: misunderstandings and gaps in a local context”. Risk, Models and Applications. Kremers and Susini (eds), CODATA Lecture Notes in Information Sciences, Berlim, 2010 (in press). 
vo até há pouco em vigor e a gestão urbanística até então praticada, não foram capazes de orientar suficientemente o processo de ocupação do território, antes se conformando com ele. ${ }^{7}$

0 planeamento, enquanto ferramenta jurídica, deve assumir como objectivo a inversão desta tendência, apresentando-se, por isso, como um instrumento indispensável para o ordenamento do espaço.

No entanto, sendo o acto de planear, por si só, diferenciador dos diversos usos e condicionalismos de utilização do território, o mesmo determina regimes de ocupação e estatutos jurídicos diferenciados para solos com condições físicas semelhantes, introduzindo iniquidades entre os proprietários onde elas não existiam. É neste contexto, e para fazer face ou corrigir as desigualdades introduzidas pelo processo de planeamento, que surgem os mecanismos perequativos de benefícios e encargos, os quais se apresentam como uma ferramenta capaz e indispensável para garantir a equidade nos processos de ocupação do território.

O seu funcionamento assenta numa lógica de compensações entre o município e os proprietários (ou estes entre si) sempre que se detectem desvios aos padrões de referência dos benefícios e dos encargos considerados equitativos. A criação de um modelo perequativo possibilita, deste modo, a obtenção de um equilíbrio mínimo e a redução das desigualdades, permitindo salvaguardar princípios básicos da política de ordenamento do território. ${ }^{8}$ Devem, por isso, as medidas perequativas ser obrigatoriamente integradas nos planos municipais, desde a sua génese, conferindo a estes uma função e um alcance mais amplos do que a de mera regulamentação do uso do solo.

2.2. A aplicação da lógica perequativa em territórios com condicionantes resultantes de processos naturais de perigosidade

a) Apesar do crescente número de instrumentos legais cujo objectivo principal é a criação de regras de gestão do território, os impactos dos riscos naturais na sociedade e no ambiente são cada vez maiores. Verifica-se que múltiplos processos naturais têm manifestações cada vez mais recorrentes e que os seus impactos são cada vez mais nefastos. Desde cheias, cujo período de recorrência é cada vez menor, passando por incêndios florestais com consequências cada vez mais devastadoras, até movimentos de vertente que, em segundos, deixam os bens das populações reduzidos a zero, as manifestações destes processos têm um impacto crescente nos indivíduos e comunidades.

Durante anos os prejuízos incutidos pelas manifestações dos diferentes perigos e a forma como o ordenadamente territorial foi catalisador das mesmas não foram alvo de estudo profundo nem de regulamentação própria. Torna-se, contudo, premente a gestão desta nova faceta dos territórios sob pena de se comprometer a sustentabilidade económica, ambiental e social dos mesmos.

b) Em face do que foi referido, e tendo em consideração as virtualidades equitativas dos mecanismos perequativos, não pode deixar de se equacionar a sua utilização (ou, pelo menos, da lógica que lhes está subjacente) para, através da sua integração em instrumentos de gestão territorial a diversas escalas, incentivar e fomentar a diminuição de riscos territoriais. ${ }^{9}$

0 que se pretende é testar a utilidade da aplicação da metodologia (e da lógica) perequativa em territórios que apresentam condicionantes de uso e ocupação resultantes de processos naturais de perigosidade, por forma a determinar se a aplicação da perequação

\footnotetext{
7 CARVALHO, Jorge e OLIVEIRA, Fernanda Paula, Perequação, Taxas e Cedências - Administração Urbanística em Portugal. Coimbra, Almedina, 2003, p.31.

8 PRINCHAK, R. F. (2004). Transferências Constitucionais de Efeito Redistributivo e Indicadores Sociais dos Municípios Baianos no Período 1998/2000: Uma Casualidade Complexa, Bahia, p. 180.
} 
a áreas de susceptibilidade natural permite introduzir no exercício do planeamento novas formas efectivas de prevenção e mitigação dos riscos.

Em causa não está, como será fácil de compreender, a aplicação, sem mais, de mecanismos de perequação urbanística de benefícios e encargos - que é aplicada na correcção de desigualdades territoriais (em termos de edificabilidades e encargos urbanísticos) introduzidas pela decisão administrativa de planeamento onde elas não existiam -, mas tão só da utilização da metodologia, dos princípios e da lógica de funcionamento em que a mesma assenta, em territórios por si já desiguais dadas as diferentes susceptibilidades associadas às perigosidades naturais.

0 que aqui se pretende obter não é a reposição da igualdade entre os vários proprietários "afectados" por decisões de planeamento (como na perequação urbanística strictu sensu), mas uma "igualdade" entre os territórios sujeitos a distintos processos naturais com consequências danosas para os seus "utilizadores" e o restante território não sujeito aos mesmos processos para, desta forma, garantir uma maior equidade territorial, que se apresenta também, e em primeira linha, como um dos objectivos essenciais da política de ordenamento do território.

Acresce a necessidade de os instrumentos de planeamento do território deverem, cada vez mais, ser elaborados tendo por base uma lógica de desenvolvimento e segurança das populações e uma adaptação ao sistema ambiental onde se vão integrar, não devendo ser perspectivados como instrumentos que se limitam a identificar ou impor um conjunto de condicionantes, indiferentes às relações entre a sociedade e o território e aos processos que neles se verificam.

$\mathrm{Na}$ óptica aqui defendida, a lógica perequativa - que funciona através de um sistema de compensações e de incentivos -, pode (e deve) ser aplicada em áreas de perigosidade natural, de forma a incentivar ou dissuadir determinadas ocupações ou práticas em áreas sujeitas a maiores riscos naturais de forma, não apenas, a corrigir desigualdades pré-existentes no território, mas também a fornecer uma nova abordagem ao conceito de risco nos processos de ordenamento e planeamento territorial e na operacionalização da gestão da emergência e socorro, os quais devem ir para além de uma simples lógica de reacção.

c) A dificuldade de prevenir e mitigar os riscos decorrentes de diferentes processos naturais e de gerir as situações de emergência e socorro por eles desencadeadas são problemas que diariamente se colocam aos responsáveis técnicos e políticos dos serviços de protecção civil, a diferentes escalas, e com que se confronta a sociedade civil em situações de desastre ou calamidade. 0 desconhecimento da capacidade de resistência e resiliência dos cidadãos e dos territórios, das dinâmicas sociais e dos grupos de risco, dos equipamentos e infra-estruturas locais, dos meios e recursos para os socorro e emergência, entre outros, são factores que exponenciam as diferentes vulnerabilidades

A integração destas preocupações no âmbito do planeamento físico do território - isto é, naqueles instrumentos de planeamento que perspectivam o território como um todo, nos seus vários factores - apresenta-se como imprescindivel, reforçando a necessidade de integração, em todo o processo de planeamento, da análise da perigosidade. ${ }^{10}$

9 BRITO, Jorge, Aplicação de Critérios Perequativos a áreas de Susceptibilidade Natural. Dissertação de Mestrado
em Geociencias, apresentada à Faculdade de Ciências e Tecnologia da Universidade de Coimbra. Coimbra, 2007,
policopiada, p. 159.
${ }^{10}$ A perigosidade é, Segundo D. Varnes, o produto da probabilidade e da susceptibilidade, sendo a probabilidade
de ocorrência, num determinado intervalo de tempo e dentro de uma determinada área, de um processo poten-
cialmente danoso. E, se assim é, também o risco (produto da perigosidade pelo dano potencial, ou, de forma mais
desagregada, o produto da probabilidadex susceptibilidade xvulnerabilidadex valor), terá de fazer parte integrante
de todo o mecanismo de gestão do território. Cfr. VARNES, D.J., Hazard Zonation: A Review of Principal and Practice. 
Neste âmbito, as técnicas cartográficas, através da explanação das relações espaciais, desempenham um papel importante para a prevenção e avaliação dos riscos, uma vez que permitem localizar fontes de perigo, determinar zonas de risco e áreas vulneráveis. Diferente métodos de análise, sejam eles 2D ou 3D, são cada vez mais utilizados como forma de avaliar os riscos e garantir a segurança.

A necessária consideração e articulação das "cartas de ordenamento" dos planos municipais com as cartas de cartas de susceptibilidade, de vulnerabilidade ou de risco tornam-se fundamentais nesta tarefa, por permitirem a melhor identificação das condicionantes dos processos ou acções de distúrbio, potenciando uma melhor utilização do espaço e dos terrenos com melhor aptidão, protegendo os recursos. ${ }^{11}$

A gestão do risco apresenta-se, assim, como uma variável imperativa ao nível das políticas de ordenamento do território, devendo ser criados mecanismos que reduzam as vulnerabilidade e o impacto dos processos perigosos e, deste modo, reduzam os seus impactes sociais, económicos e ambientais. Precisamente por não se terem considerado os riscos no processo de planeamento e de gestão do território, estes acabaram por potenciar a elevada susceptibilidade que caracteriza muitas áreas do território nacional.

A conclusão fundamental a que se chega é a de que deve ser criada uma cultura de prevenção do risco através da integração da sua consideração nas políticas de desenvolvimento e ordenamento territorial, contemplando nestas a mitigação, resposta e recuperação dos vários processos naturais, através, designadamente da criação de um conjunto de incentivos a determinadas atitudes, à semelhança dos incentivos à adopção de boas práticas propostos no $13^{0}$ Fórum Global da Biodiversidade (1999).

A criação de medidas de incentivo ajuda a modificar comportamentos e encoraja os indivíduos, as organizações e as empresas a participar activamente nos processos. Ora, é neste domínio que os mecanismos perequativos, com a sua lógica de criação de compensações, assumem o seu maior relevo.

\section{Aplicação da metodologia perequativa em áreas de susceptibilidade natural: um caso de estudo}

Com o intuito de comprovar a valia da aplicação de mecanismos assentes numa lógica perequativa a espaços onde existem processos naturais de perigos, considerou-se essencial definir uma metodologia de trabalho a aplicar a uma determinada área de estudo.

\subsection{A metodologia de trabalho}

A metodologia adoptada pressupôs a definição de vários passos que foram sendo cumpridos de forma sucessiva.

O primeiro consistiu na diferenciação do território de acordo com os distintos graus de susceptibilidade a processos naturais nele existentes, como movimentos de massa em vertentes, cheias e inundações, bem como incêndios florestais.

Num segundo momento procedeu-se ao levantamento, classificação e organização dos elementos expostos, quantificou-se o seu valor económico-individual e analisou-se a resiliência e resistência social e infra-estrutural instaladas, com vista a determinar a vulnerabilidade da população residente. Isto porque uma metodologia assente numa lógica perequativa pressupõe quantificar os prejuízos económicos potenciais resultantes das várias manifestações do perigo, através da valoração económica dos elementos expostos, utilizando valores médios

Commission of Landslide of IAEG, UNESCO, Natural Hazades, №.3, 61, 1984.

${ }^{11} \mathrm{~A}$ análise e gestão do risco resultam da análise combinada da perigosidade, susceptibilidade e vulnerabilidade. Cfr. ZÊZERE, J.L. - Distribuição e ritmo dos movimentos de vertente na Região a Norte de Lisboa. Centro de Estudos Geográficos, Área de Geografia Física e Ambiente, Rel. nํㅜ 38, Lisboa, 167 p, 2001 
de referência (construtivos, materiais, de equipamentos, agrícolas, florestais) disponíveis para uma determinada área em estudo.

Complementarmente foi analisada a componente social a partir das características da população (população residente, grupos de risco) e da dependência relativa a infra-estruturas e equipamentos com cariz social, educativo ou de saúde. A combinação destas duas variáveis permitiu determinar a expressão da vulnerabilidade social do território, de acordo com o esquema patente na Figura 1.

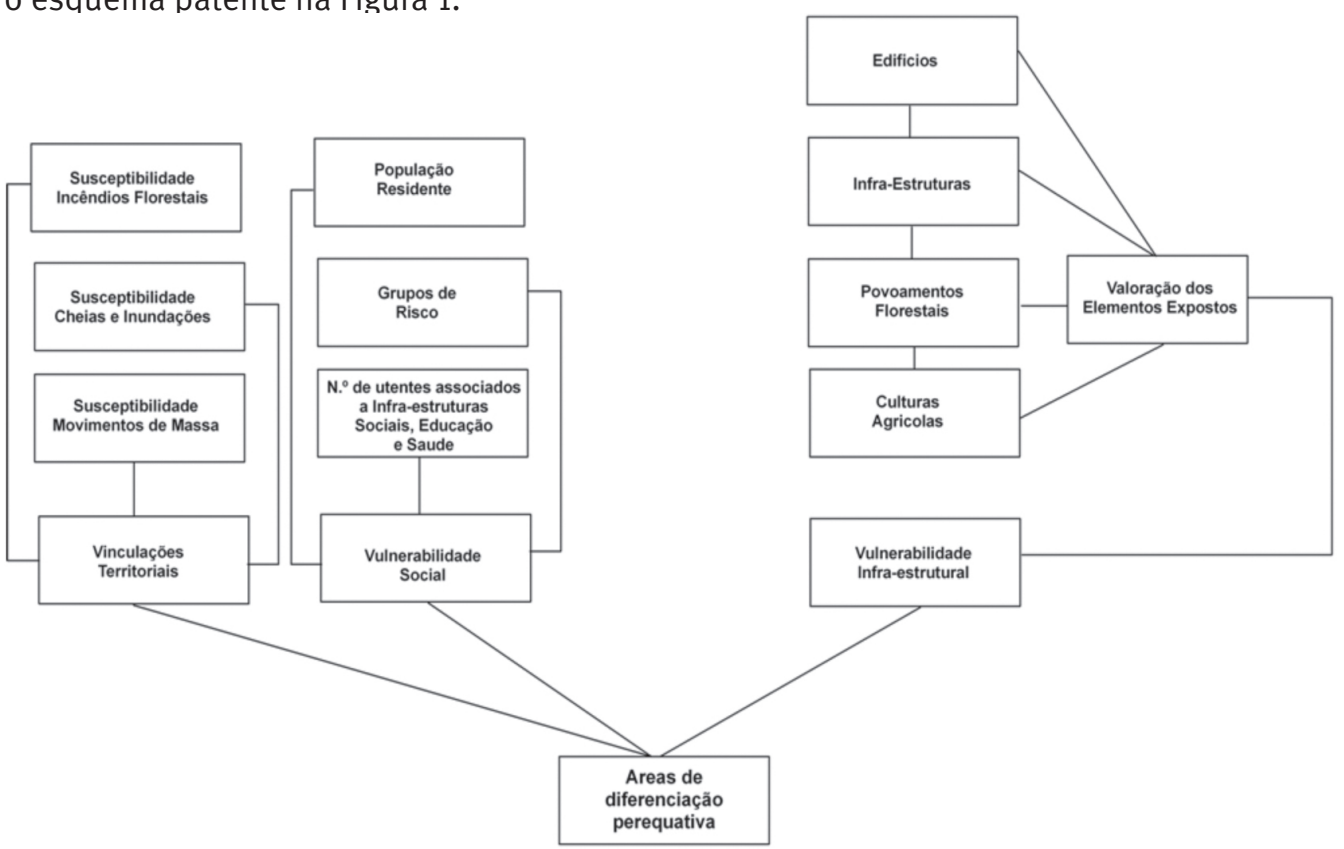

Figura $n .{ }^{0} 1-$ Processos e elementos presentes no território

A análise dos processos e das capacidades presentes no território permitiu identificar os sectores mais valiosos, quantificar as suas benfeitorias e, paralelamente, quantificar perdas e custos (perdas de salários, diminuição da qualidade de vida, deterioração da paisagem e degradação ambiental). A espacialização destes atributos e a sua análise compósita permitiram ainda zonar territórios por distintos graus de exposição aos perigo, em relação aos quais se considerou deverem ser aplicadas formas de gestão diferenciadas tendo por base mecanismos assentes numa lógica perequativa, que diferencia os territórios na aplicação e gestão das políticas públicas, incentiva as populações a adoptar medidas de auto protecção, beneficiando-as por tal, contrapondo com penalizações quando se manifeste inércia na adopção de medidas de prevenção, redução e mitigação destes processos.

\subsection{A área de estudo}

\subsubsection{Caracterização}

Para a aplicação da metodologia descrita, foi seleccionada como área de estudo, um espaço com características periurbanas (que materializa uma interface urbano/rural), em relação à qual existem registos históricos de processos naturais (movimentos de massa em vertentes, cheias e inundações, incêndios florestais) com perdas e danos associados. ${ }^{12}$

$\overline{{ }_{12}}$ TAVARES, A. O. \& CUNHA, L. "Perigosidade natural na gestão territorial. 0 caso do município de Coimbra”. A Terra Conflito e Ordem. Ed. MMGUC, 2008, pp. 89-100. 
Trata-se de uma área com cerca de $45 \mathrm{~km} 2$, localizada na região centro de Portugal, no concelho de Coimbra, integrando, total ou parcialmente, oito das freguesias da margem esquerda do principal elemento hidrográfico da região, o Rio Mondego (Mapa n. ${ }^{0}$ ).

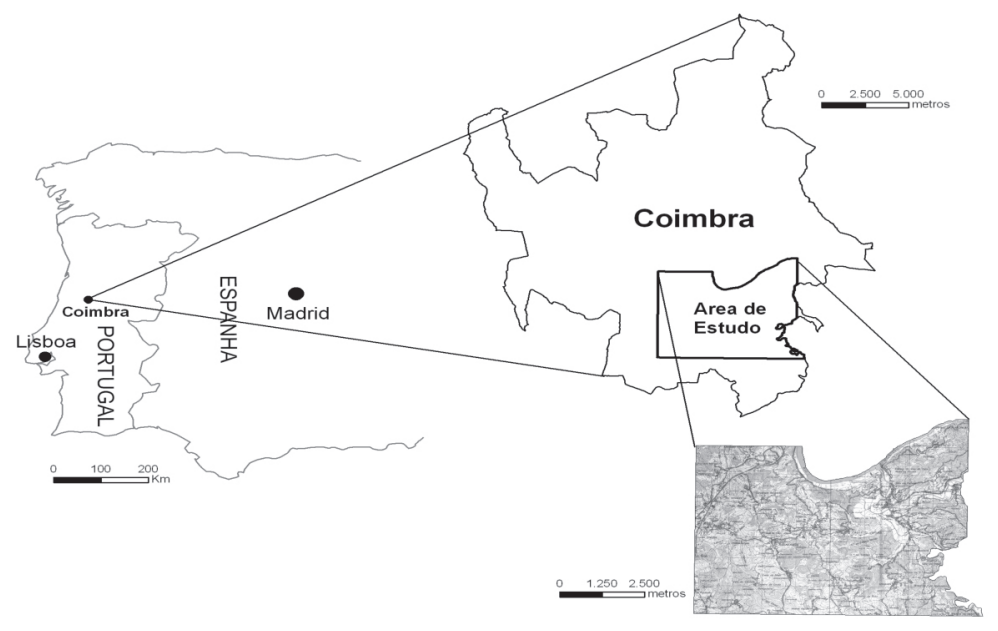

Mapa n. ${ }_{1}$ - Enquadramento geográfico da área

a) Morfologicamente a área é contrastada, variando a hipsometria entre $25 \mathrm{~m}$ e $250 \mathrm{~m}$, caracterizando-se o sector mais oriental por uma orografia típica do maciço marginal de Coimbra, vincada por fortes declives e vales incisivos, em oposição ao sector Ocidental onde os declives são mais suaves com predominância de valores entre 2 e $5 \%$. A área é limitada a Norte pelas vertentes declivosas do vale assimétrico do rio Mondego, que recebe em confluência ortogonal o rio Ceira, o qual apresenta um traçado irregular, condicionado pelas direcções da fracturação N-S e NE-SW, num vale encaixado em forma de $\mathrm{V}$, recebendo numa depressão aplanada o afluente rio Dueça que delimita em meandros apertados a área a Este.

A geologia, marcada por uma fracturação bastante densa, aparece representada pelas unidades metamórficas xistentas e grauvacóides da Série Negra, pelas unidades arenosas, conglomeráticas, pelíticas e carbonatadas do Grupo de Silves, pelas unidades carbonatadas do Grupo de Coimbra, pelas unidades margo-calcárias jurássicas, pelos arenitos cretácicos da Figueira da Foz, e por depósitos superficiais quaternários, nomeadamente aluvionares. ${ }^{13}$

b) 0 clima existente na área é tipicamente mediterrâneo, caracterizado por Verões secos e quentes e Outonos e Invernos com chuvas fortes. A temperatura média anual é de $15,3^{\circ}$ C, podendo, contudo, atingir máximos consideráveis na época estival de $45,8^{\circ} \mathrm{C}$. Os ventos dominantes são do quadrante NW com uma velocidade que ronda os $6,7 \mathrm{~km} / \mathrm{h}$, registandose, porém, valores igualmente significativos do quadrante SE com velocidades médias de $10,7 \mathrm{~km} / \mathrm{h}$.

c) No que concerne às características da ocupação e uso do solo (cfr. Mapa 2) salienta-se a extensa área ardida em 2005, a qual era previamente ocupada por floresta de resinosas ou mista. Actualmente, e independente dos processos de reflorestação e regeneração natural, os espaços florestais continuam a ser dominantes, correspondendo ao sector SSW a maior área de espaços florestais degradados.

${ }_{13}$ Soares, A., Marques. J., Rocha. R., Sequeira, A. (2005). Carta Geológica de Portugal, na escala de 1:50 ooo, Folha 19-D (Coimbra - Lousã). 


\section{$\operatorname{RerCEDőUA~}$}

\section{$>$ Doutrina}

O uso agrícola é importante na área, equivalendo a cerca de $10 \mathrm{~km} 2$. Nos plainos aluvionares as culturas anuais são essencialmente de regadio ou sequeiro e nos solos do substrato calcário a ocupação agrícola é predominantemente associada a pomares.

No sector ocidental verifica-se a maior complexidade no que concerne ao uso e ocupação do território, com uma presença urbana descontínua, ocupação industrial, comercial ou com equipamentos associados a usos agrícolas e florestais, como pode ser observado no Mapa no 2. É ainda neste sector que se encontram as sub-secções estatísticas com maior densidade populacional (INE, 2001), com valores superiores a $311 \mathrm{hab} / \mathrm{km}^{2}$, realçando-se, a oriente, os aglomerados populacionais concentrados de Ceira, Sobral do Ceira e Anagueis.

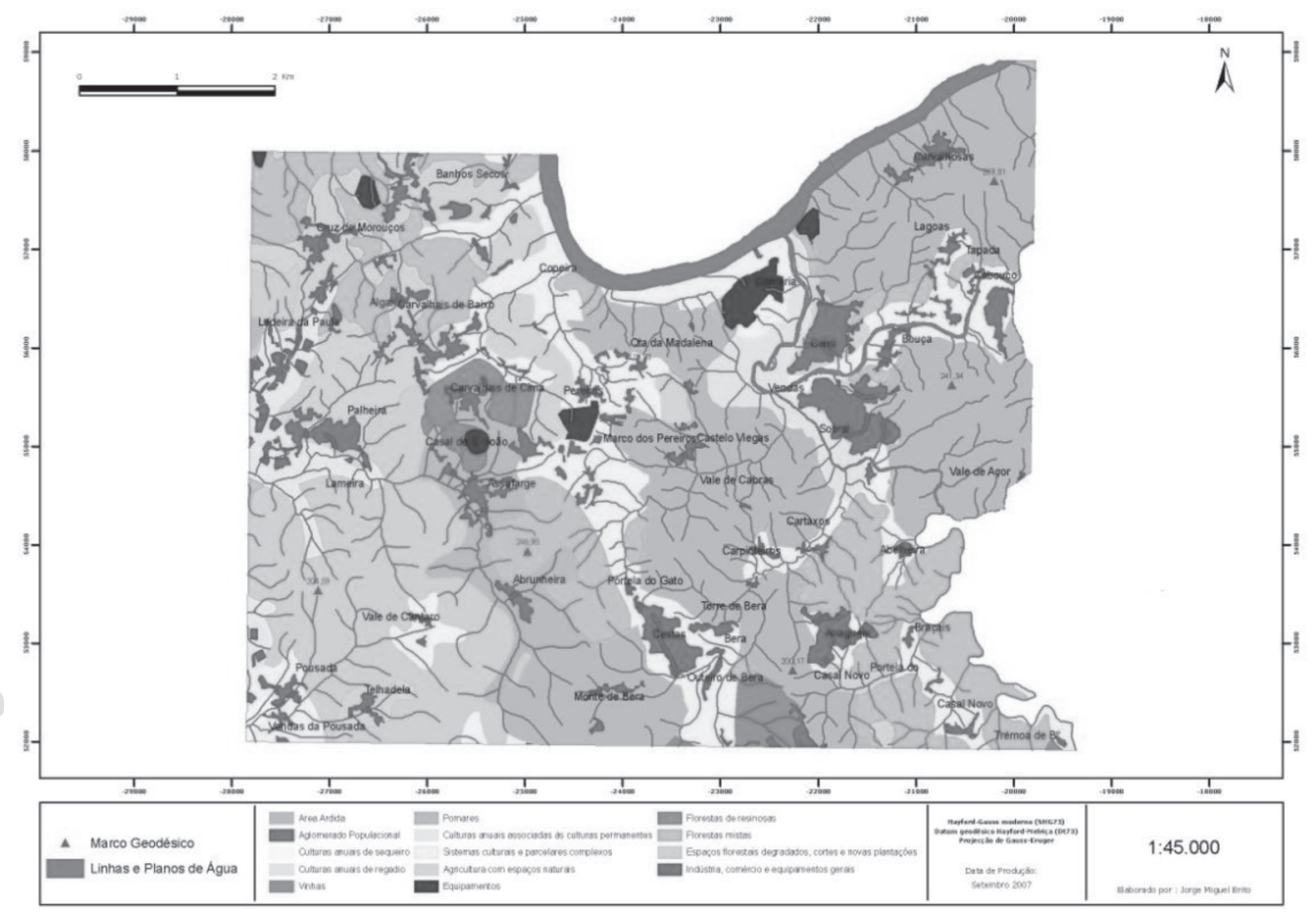

Mapa n.ำ 2- Uso e ocupação do solo

d) No que diz respeito à distribuição das actividades económicas, observa-se o predomínio das actividades agrícolas e relacionadas com o sector florestal a Este, apesar do seu recente declínio, concentrando-se a Oeste as actividades industriais e comerciais, com ramos diversos. Os equipamentos encontram alguma rarefacção em direcção a Sul, verificando-se, nos equipamentos de resposta local, uma relação directa entre a tipologia e as características demográficas da população. Existem, ainda, na área de estudo, equipamentos de carácter nacional como o Hospital Psiquiátrico de Sobral Cid, e a Universidade Vasco da Gama, assim como infra-estruturas de valor local a nacional, nomeadamente rodoviárias e infra-estruturas de distribuição energética. 
e) Historicamente a área de estudo apresenta uma vasta série de registos de manifestação de várias formas de perigosidade, destacando-se os incêndios florestais, as cheias e inundações e os movimentos de massa em vertente.

$\mathrm{Na}$ Tabela 1 estão representados alguns registos de perigosidade recente na área, a partir da colecção de registos da Companhia de Bombeiros Sapadores de Coimbra (CBS) e do Serviço Municipal de Protecção Civil (SMPC) da Câmara Municipal de Coimbra.

\begin{tabular}{|l|r|r|}
\hline Localização & Tipologia & Ano \\
\hline Assafarge & Incêndio Florestal & 1990 \\
\hline Castelo Viegas & Incêndio Florestal & 1995 \\
\hline Vale de Cântaro & Incêndio Florestal & 2000 \\
\hline Castelo Viegas & Incêndio Florestal & 2003 \\
\hline Ceira/Castelo Viegas & Incêndio Florestal & 2005 \\
\hline Cabouco & Cheia/Inundação & 1995 \\
\hline Cabouco/Ceira/Conraria & Cheia/Inundação & 2000 \\
\hline Cabouco/Ceira/Conraria & Cheia/Inundação & 2001 \\
\hline Cabouco & Cheia/Inundação & 2006 \\
\hline Conraria & Movimentos de massa em vertente & 1996 \\
\hline Tapada de Ceira & Movimentos de massa em vertente & 2000 \\
\hline Cabouco & Movimentos de massa em vertente & 2000 \\
\hline Hospital Sobral Cid & Movimentos de massa em vertente & 2001 \\
\hline Vendas de Ceira & Movimentos de massa em vertente & 2006 \\
\hline
\end{tabular}

Tabela $\mathrm{n} . \stackrel{0}{1}$ - Processos de perigosidade natural registados na área em estudo

3.2.2. As perigosidades na área de estudo

A cartografia da susceptibilidade relacionada com incêndios florestais é condicionada por factores fisiográficos, factores ligados à ocupação do solo e factores atribuídos ao comportamento humano.

A susceptibilidade a incêndios florestais da área de estudo é que se encontra representada no Mapa $n^{0} 3^{14}$ e utilizando a metodologia da $\mathrm{DGRF}^{15}$, permitindo a classificação de cinco categorias de susceptibilidade.


Municipal de Coimbra, p. 112.

${ }^{15}$ DGRF - Direcção Geral dos Recursos Florestais (2006). Guia para a elaboração de Planos Municipais de Defesa da Floresta Contra Incêndios. p. 220. 


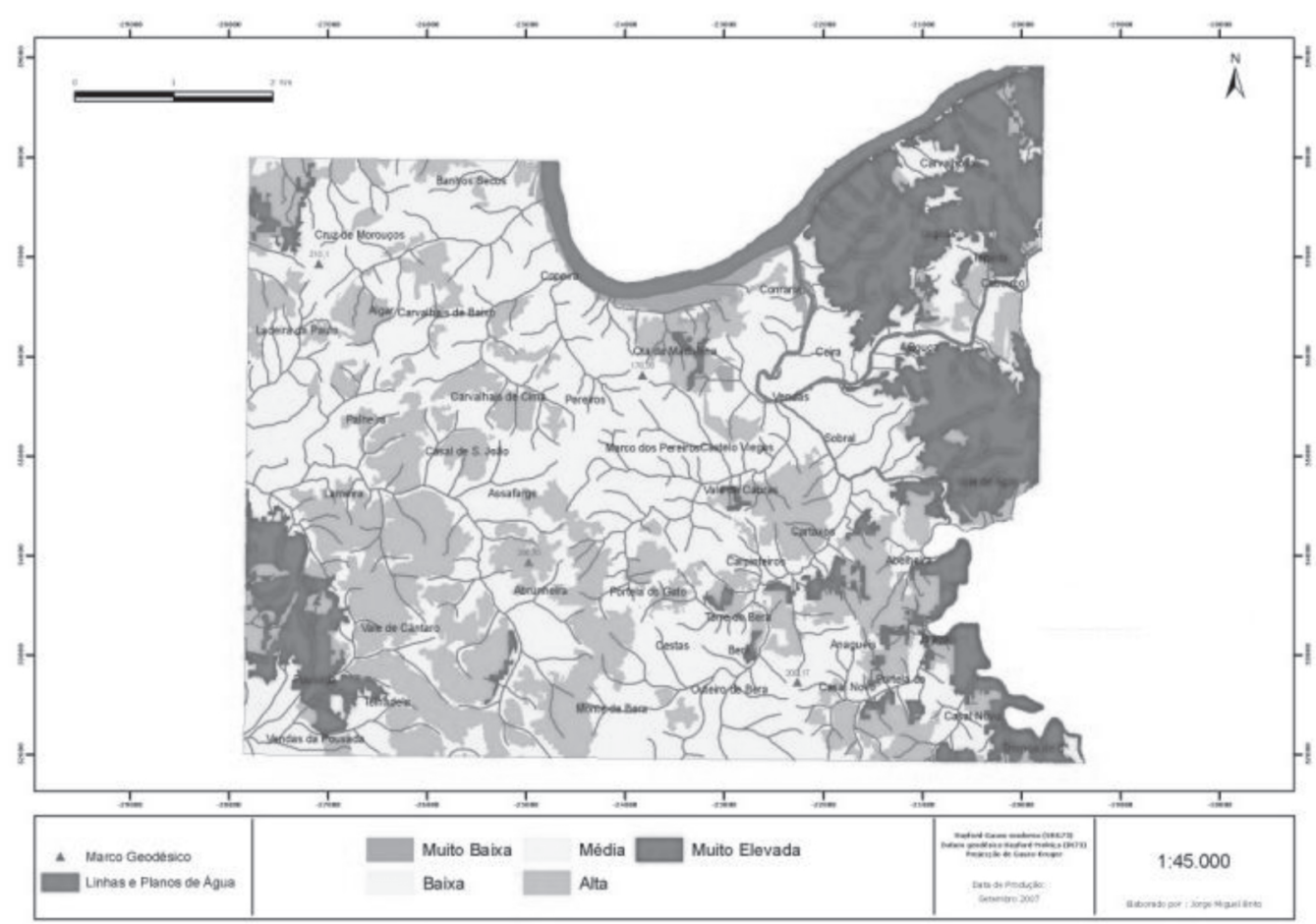

Mapa $\mathrm{n} . \stackrel{0}{3}$-Susceptibilidade a incêndios florestais a partir de da metodologia SCRIF (2004)

A carta revela uma predominância de áreas com susceptibilidade baixa (cerca de $35 \%$ da área total), enquanto as classes da susceptibilidade muito elevada e elevada representam no conjunto $44,6 \%$ da área de estudo, destacando-se, neste contexto, os espaços onde predominam as florestas de resinosas e os incultos, bem como com condições fisiográficas marcantes.

As cheias e inundações são processos recorrentes na área de estudo, sendo resultantes do regime e dinâmica semi-torrencial dos rios Mondego e Ceira.

O Mapa n- 4 ilustra as áreas sujeitas a cheias e inundações ou caracterizadas por nível freático elevado. ${ }^{16}$

${ }^{16}$ TAVARES, A.; \& CUNHA, L. (2006). Áreas inundáveis e pontos críticos de escoamento superficial no Município de Coimbra. DCT-FCTUC e CMC, Relatório não publicado, 13 p. 1, Mapa A. 


\section{$\operatorname{RerCED\varrho ̈UA~}$}

$>$ Doutrina

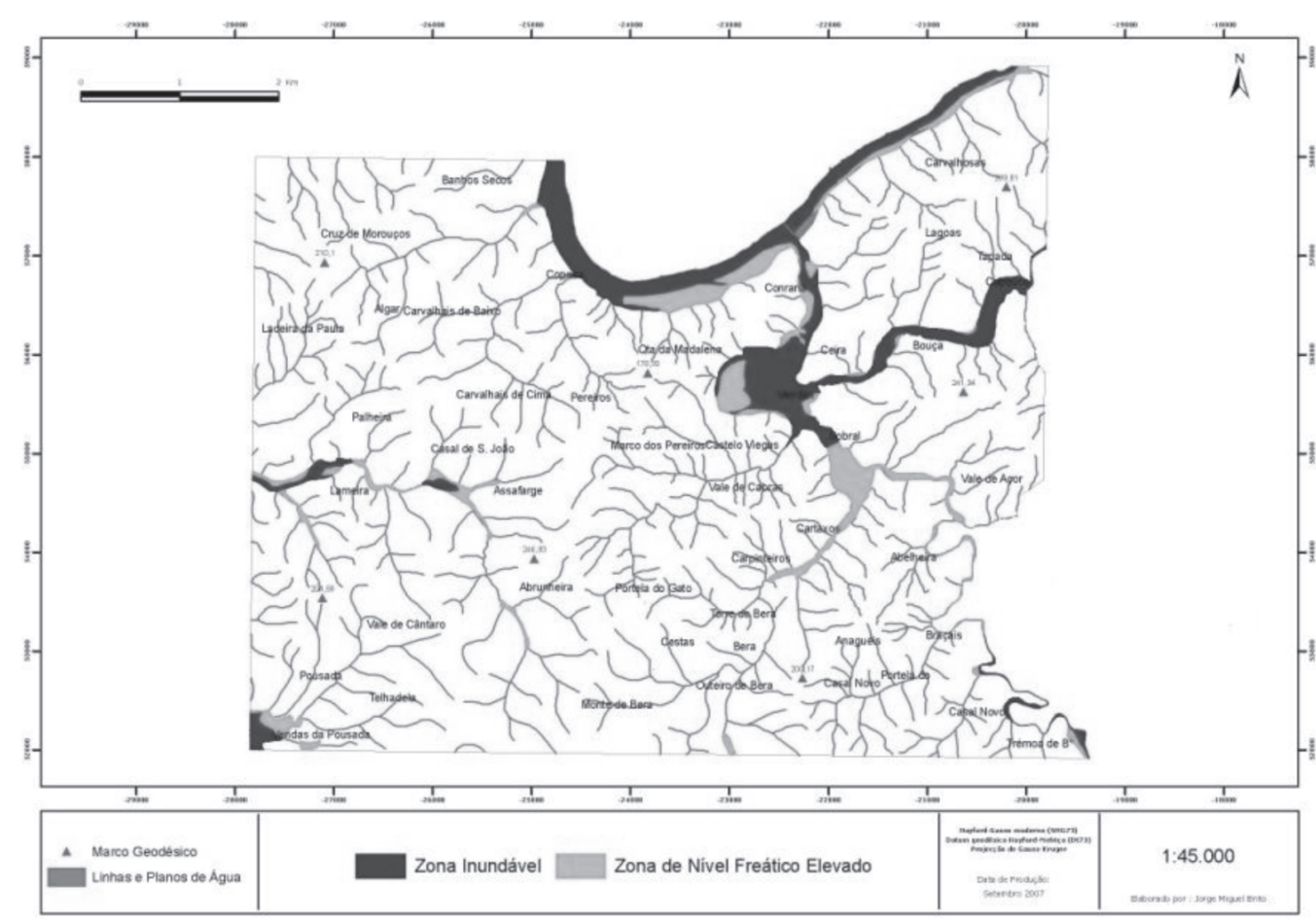

Mapa $\mathrm{n}^{0} 4$ - Susceptibilidade a cheias e inundações

As áreas ameaçadas por cheias e inundações representam cerca de $5 \%$ do total da área e são dominantemente contíguas às margens das linhas de água principais (o Rio Mondego e o Rio (eira). As áreas que apresentam nível freático elevado representam cerca de 3\% do total da área.

Por sua vez a ocorrência de movimentos de massa em vertentes na área de estudo está normalmente associada a períodos com elevada precipitação. A susceptibilidade a estes processos aparece representada no Mapa $n^{0} 5 \cdot{ }^{17}$

${ }_{17}$ TAVARES, A.; \& CUNHA, L. (2006). Perigosidade associada a movimentos de massa em vertentes. DCT-FCTUC e CMC, Relatório não publicado, 4 p. 1. 


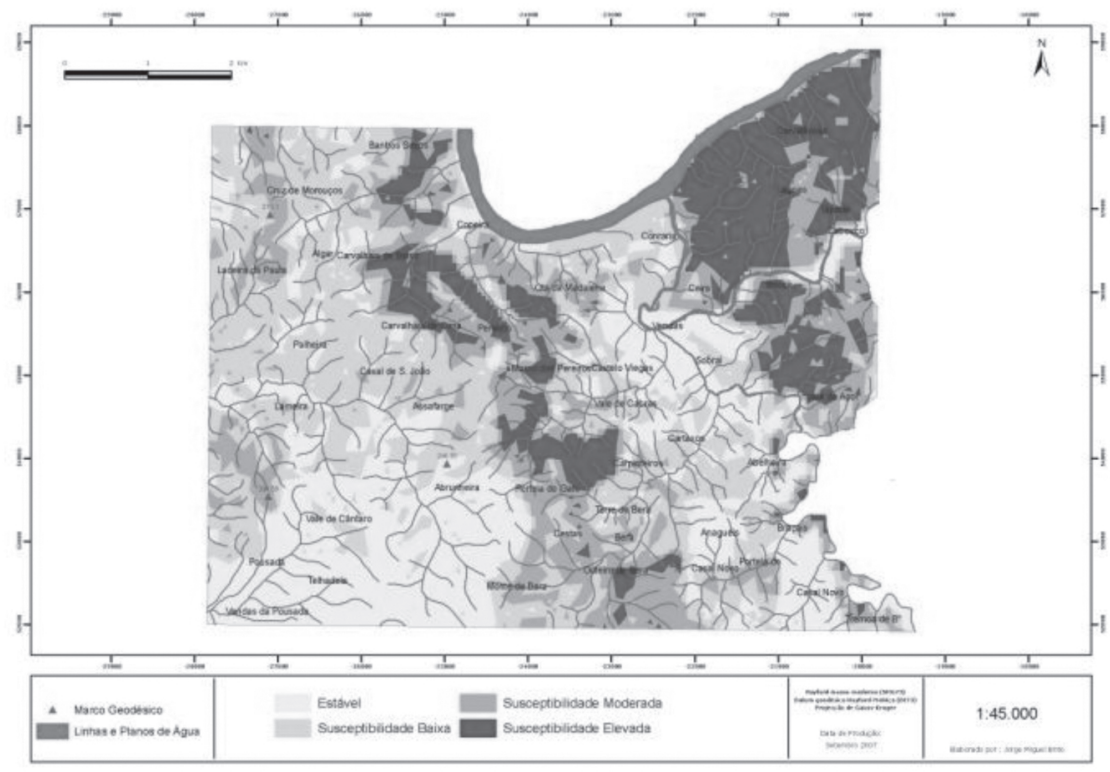

Mapa.$^{\circ} \stackrel{0}{5}$ - Susceptibilidade a movimentos de massa em vertente

Cerca de $30 \%$ da área é considerada estável (com especial incidência a sudoeste); 35\% apresenta baixa susceptibilidade; $20 \%$ corresponde a susceptibilidade moderada, sendo $15,5 \%$ áreas com susceptibilidade elevada com especial incidência a nordeste e num corredor central.

\section{Caracterização da exposição e da vulnerabilidade}

As diversas manifestações de perigosidade natural causam perdas económicas e sociais bastante avultadas. Por esse motivo considerou-se essencial identificar os vários elementos expostos na área estudo e quantificar-se os custos e perdas quer de natureza social quer económica, associados à sua destruição.

a) Vulnerabilidade social

A avaliação da vulnerabilidade social na área de estudo foi calculada através da combinação de múltiplas variáveis que permitem um retrato da distribuição geográfica dos diferentes elementos expostos e o zonamento dos diferentes graus de vulnerabilidade.

Com base na análise da população residente (PR); dos grupos de risco ${ }^{18}(\mathrm{GR})$ e dos utentes dos equipamentos de saúde, escolares e das instituições de solidariedade social (PA), foram construídos cartogramas parcelares que deram origem a uma síntese espacial destas variáveis.

A população residente e os grupos de risco foram tratados com base nos dados dos Censos de 2001 (INE, 2001), à escala da sub-secção estatística. Na análise da importância da exposição dos equipamentos de saúde, escolares e a instituições de solidariedade social quantificou-se o número de pessoas afectas/dependentes destes equipamentos e referenciou-se a área de influência dos mesmos. Na análise da vulnerabilidade social decorrente da afectação das variáveis expostas aos processos de perigosidade considerou-se uma ponderação diferenciada.

\footnotetext{
${ }^{18}$ População Presente com $\geq 14$ anos e $\geq 65$ anos sujeita a determinados factores ou com determinadas características, que a tornam mais vulnerável perante determinados processos.

Cfr. DWYER, A.; ZOPPOU, C; NILSON, O.; DAY, S \& ROBERTS, S. (2004) - Quantifying social vulnerability: a methodology for identifying those at risk to natural hazards, Geoscience Australia, Australian Government, № 14, p. 101.
} 
Assim, a expressão da vulnerabilidade social (Vs) foi obtida a partir do seguinte algoritmo: $\mathrm{Vs}=2 \times \sum \mathrm{GR}+2 \times \sum \mathrm{PA}+\sum \mathrm{PR}$.

A expressão desta análise encontra-se exposta no Mapa $\mathrm{n}-6$, tendo sido obtida após um processo de normalização e generalização cartográfica.

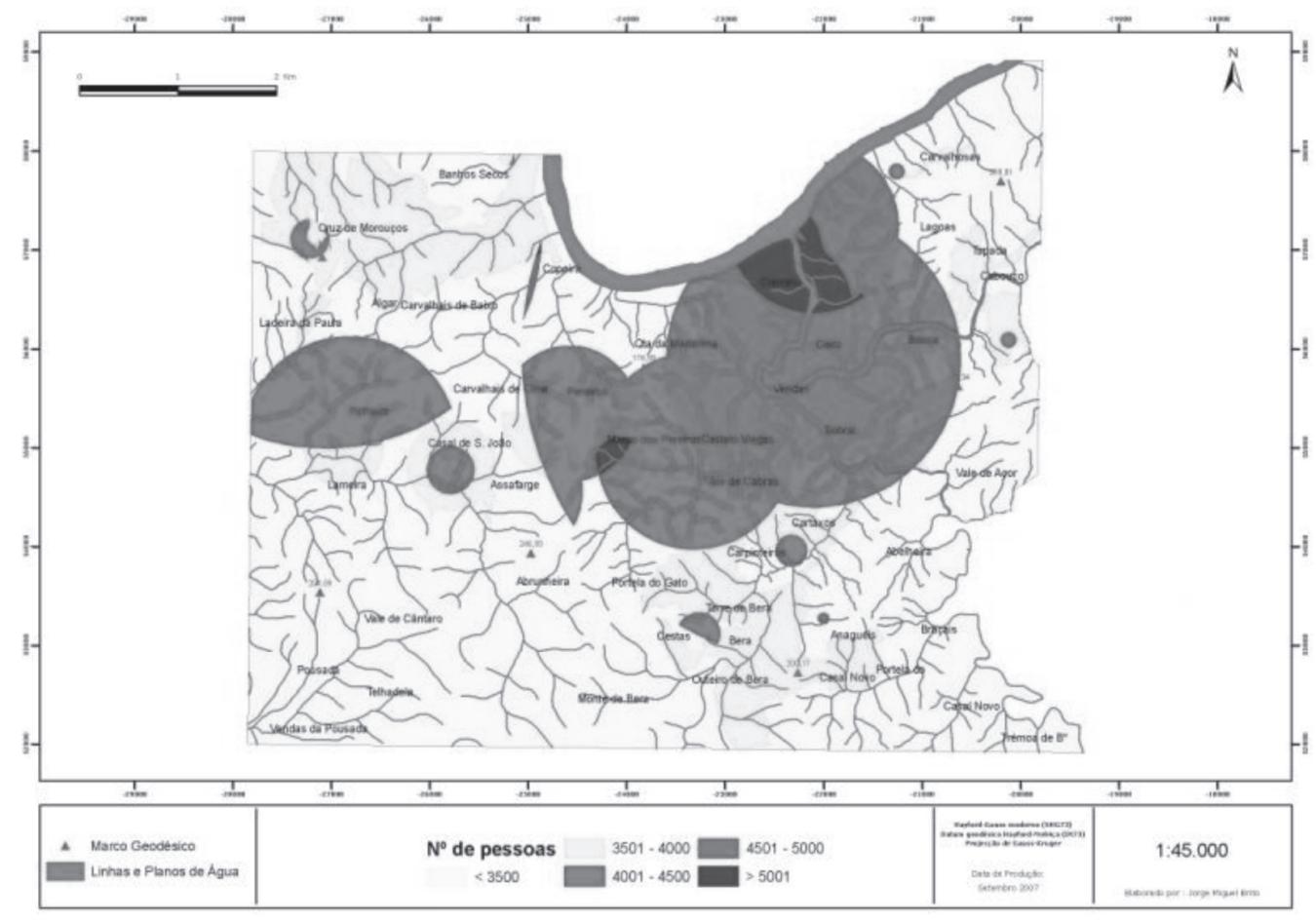

Mapa $\mathrm{n} . \stackrel{6}{6}$ - Vulnerabilidade social

Os resultados obtidos foram posteriormente agrupados em classes de intervalos iguais, permitindo dar expressão territorial à vulnerabilidade social. Do Mapa n. 06 retira-se a existência de uma bacia de vulnerabilidades sociais que se estende ao longo dos rios Ceira e Dueça, permitindo identificar os sectores onde existe um número elevado de população afecta a Hospitais, Escolas ou Instituições Sociais.

b) Vulnerabilidade infra-estrutural

A análise da exposição e da vulnerabilidade infra-estrutural da área de estudo baseou-se no levantamento e na valoração dos diferentes elementos presentes no território, a que foi atribuído o valor económico de mercado ou de reconstrução, em resultado da afectação e destruição por processos naturais perigosos.

Após a inventariação dos elementos expostos estabeleceram-se, quatro grupos de análise e valoração: (1) edifícios de habitação e equipamentos; (2) infra-estruturas viárias, hidráulicas, energéticas, entre outras; (3) povoamentos florestais; (4) culturas agrícolas.

As subdivisões tipológicas consubstanciam a diversidade de distribuição territorial das infra-estruturas e foram objecto de quantificação a partir de diferentes critérios e fontes, conforme expresso na Tabela 2. 


\section{RerCED光UA}

\section{$>$ Doutrina}

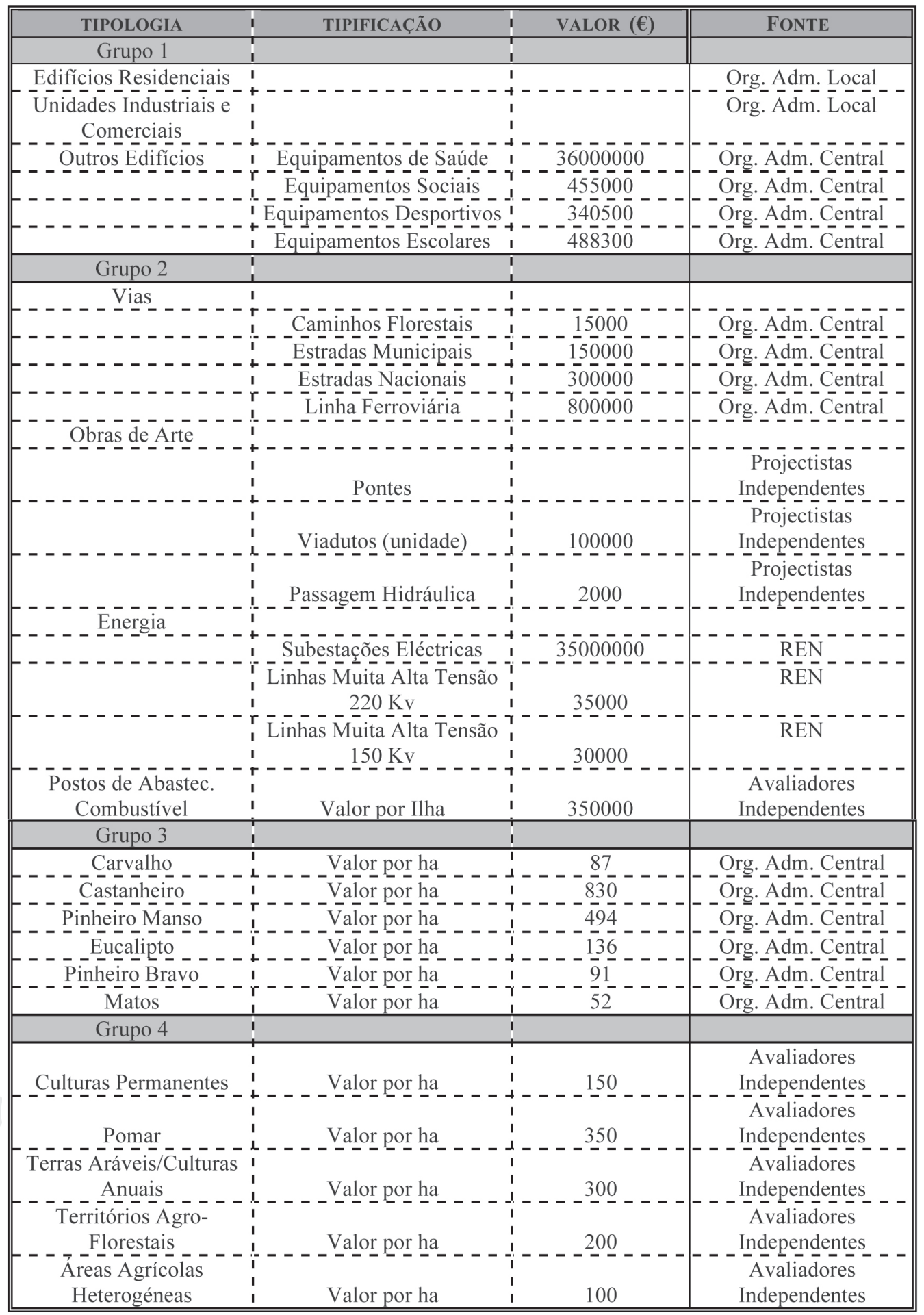

Tabela n.ํㅜ 2 - Valor estimado Tipologia, Tipificação e Valoração dos elementos expostos 
O somatório dos valores espaciais dos vários elementos expostos encontra-se representado no Mapa $n^{0}$ 7, tendo os processos de união, com uma unidade de agregação mínima de 1 ha, valores entre $102863908 €$ (expressando o valor do edifício do Hospital Psiquiátrico de Sobral Cid) e $52 €$ (genericamente o espaço rural com ocupação agrícola ou florestal residual).

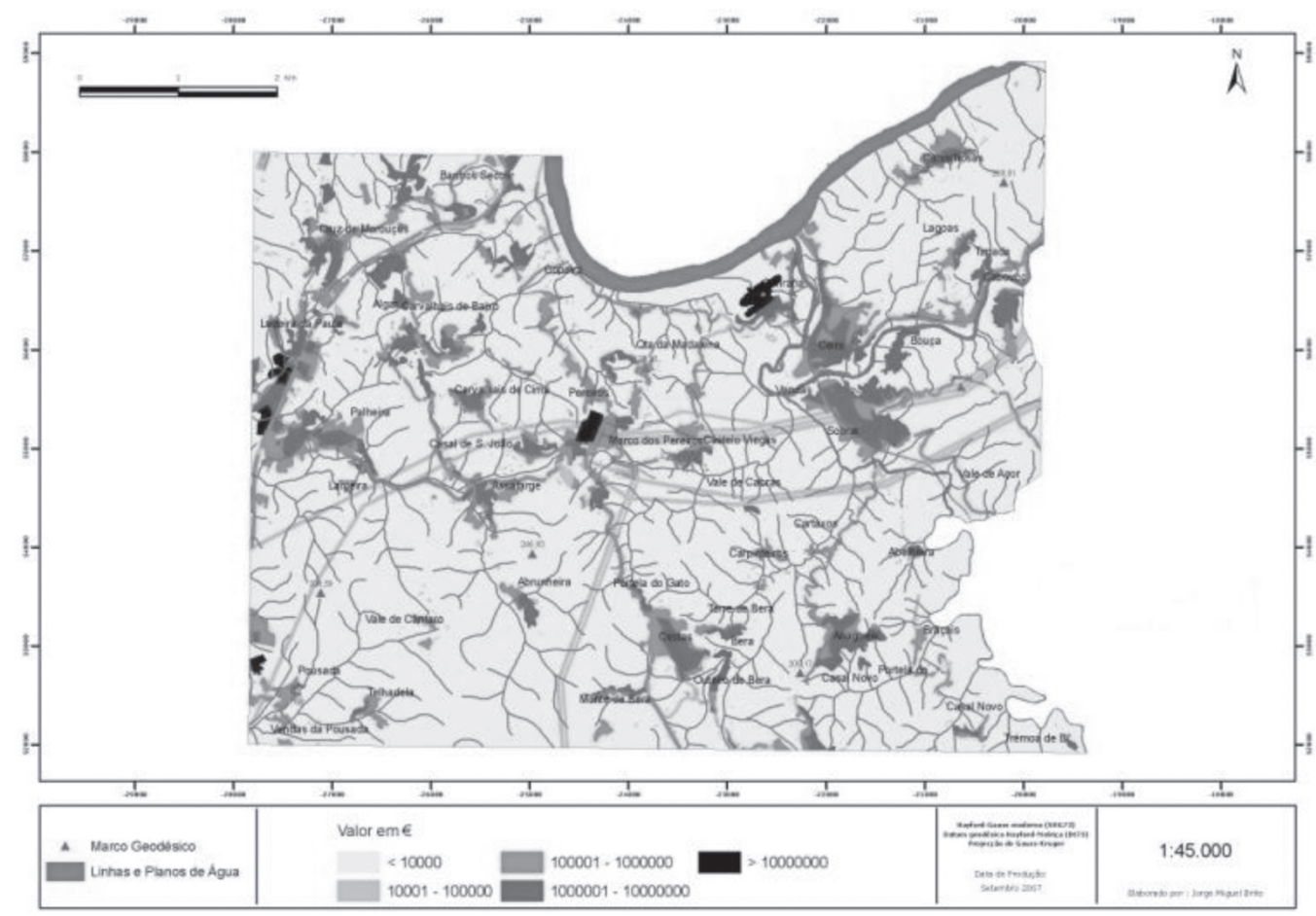

Mapa $n . \stackrel{0}{7}$ - Vulnerabilidade infra-estrutural dos elementos expostos

A cartografia encontrada, utilizando uma escala logarítmica para os valores, permitiu identificar polígonos com valores superiores a $10000000 €$ (Hospital Sobral Cid, Quinta da Conrraria e algumas áreas industriais), o edificado urbano (Ceira, Sobral, Anaguéis, Pereiros, Portela do Gato e Palheira), assim como as infra-estruturas rodoviárias regionais e nacionais e as linhas de Muita Alta Tensão, por oposição aos espaços florestais, agrícolas e naturais.

\section{Aplicação dos critérios perequativos}

a) Conhecida a expressão territorial parcelar de cada uma das perigosidades consideradas, foi obtida a expressão compósita resultante da ponderação crescente das classes de susceptibilidade.

Para o efeito, estabeleceu-se 5 como o peso máximo da representação territorial de cada perigo, correspondendo a 15 a parcela de territórios que apresentam simultaneamente elevada susceptibilidade à ocorrência de incêndios florestais, cheias e inundações e movimentos de massa.

Com base nesta análise compósita da perigosidade, foram estabelecidas vinculações territoriais resultantes do agrupamento em quatro classes crescentes, com base no método de quebras naturais, tendo-se procedido à criação de uma quinta classe que individualiza os espaços em que está presente um perigo na sua forma mais elevada de susceptibilidade.

Na Tabela $\mathrm{n}-4$ aparecem representadas as classes, com o correspondente valor ponderado da susceptibilidade, e a respectiva vinculação territorial. 


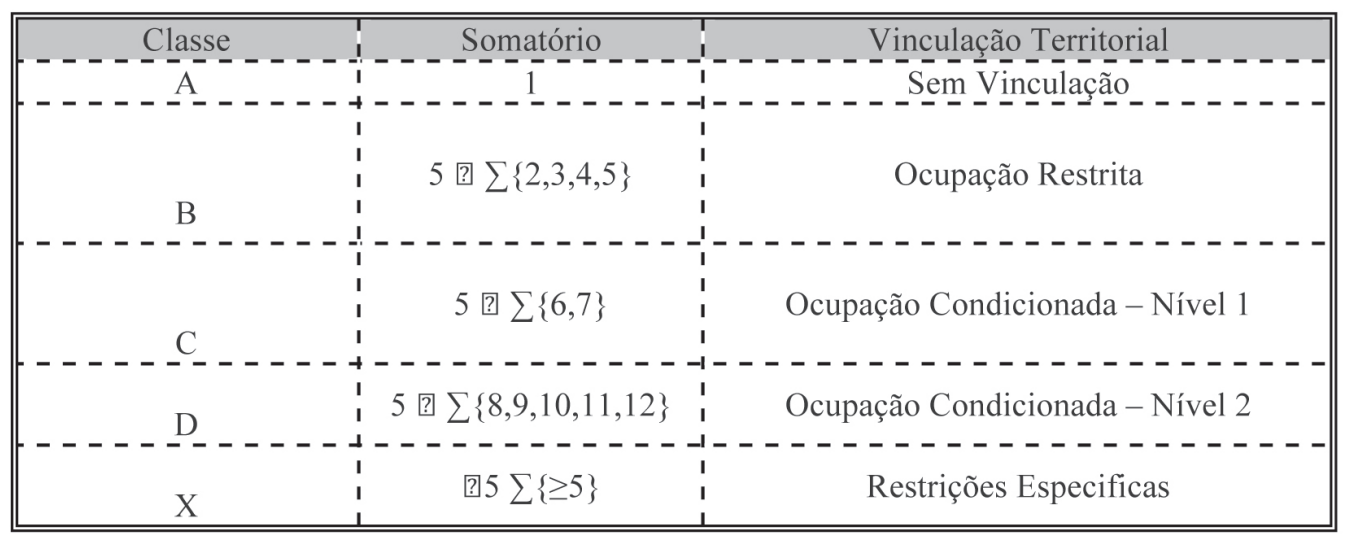

Tabela n. ${ }^{4}$ - Classes compósitas de susceptibilidade e vinculações territoriais

No mapa ํo 8 são representadas as vinculações territoriais propostas para a área de estudos: a classe $A$ representa os espaços onde não se prevê a materialização de qualquer processo natural de perigo, pelo que não devem suportar qualquer vinculação; a classe $B$ corresponde às áreas cujo somatório de susceptibilidade varia entre 2 e 5 , onde se considera recomendável algumas restrições na ocupação; as classes $C$ e $D$ representam os territórios nos quais se projectam valores mais elevados de susceptibilidade conjugada para os três processos (incêndios florestais, cheias e inundações, movimentos de instabilidade em vertentes), e em relação aos quais, por esse motivo, se considerou deverem ser determinadas condicionantes na respectiva ocupação.

A classe X caracteriza os espaços em que pelo menos um dos processos apresenta o grau superior de susceptibilidade, decorrendo deste facto a necessidade de estabelecimento de estratégias específicas de análise e utilização.

Nas áreas classificadas como Sem Vinculação não há necessidade de aplicação de quaisquer "mecanismos perequativos", dado que não estão cartografadas manifestações de qualquer dos três processos de perigosidade natural que diferenciem o território.

Nas áreas com Ocupação Restrita propõe-se a adopção de incentivos às boas práticas de uso e ocupação do território, numa lógica preventiva, e de redução da severidade dos processos; podem estabelecer-se, em áreas com vulnerabilidade social e infra-estrutural elevadas, imposições específicas para as várias entidades que gerem e transformam o território.

Nas áreas com Ocupação Condicionada haverá lugar a medidas restritivas de ocupação e transformação, limitando as acções, impondo critérios de salvaguarda ou a adopção de medidas de redução do perigo. Para as áreas de Nível 2 de Ocupação Condicionada defendese a adopção de medidas restritivas e limitativas de maior grau ou a definição de um regime de salvaguarda mais estrito ou a implementação mais efectiva e a curto prazo de medidas de redução do perigo.

Nas áreas com Restrições Especificas deverão ser tomadas medidas efectivas e imediatas de redução e mitigação dos processos de perigosidade e a adopção de práticas para redução da vulnerabilidade.

Uma análise atenta da área de estudo permite concluir que os sectores territoriais Sem Vinculação são os de menor expressão cartográfica, representando cerca de $9 \%$ do território; os territórios com Ocupação Restrita têm a maior expressão representando cerca de $40 \%$ da área total; a Ocupação Condicionada - Nível 2 ocorre em cerca de 30\% do território e a Ocupação 
Condicionada - Nível 1 em 21\%, numa área geográfica bem demarcada. Os territórios com Restrições Especificas ${ }^{19}$ apresentam uma distribuição alargada na área, representando cerca de $30 \%$.

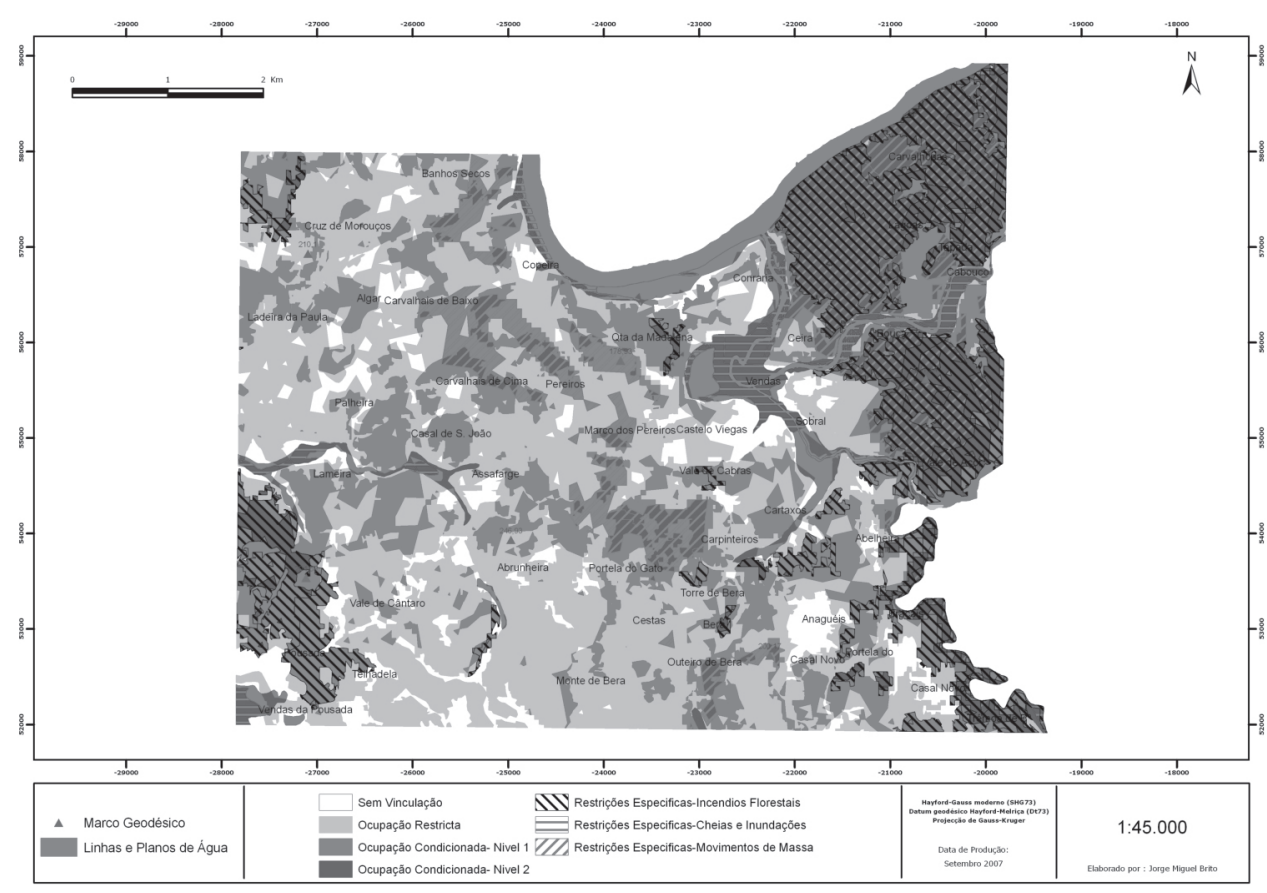

Mapa $\mathrm{n} . \stackrel{0}{8}$ - Vinculações territoriais

b) Conhecidas as vinculações territoriais determinadas pela expressão da susceptibilidade dos processos naturais e o cruzamento com a quantificação da vulnerabilidade social e infra-estrutural, foi possível diferenciar territórios para aplicação da lógica perequativa. Decorrente desta avaliação concluiu-se pela existência:

- de elementos infra-estruturais em áreas com ocupação condicionada e com restrições específicas, nomeadamente associadas a inundações em determinados sectores na povoação de Palheira;

- de elementos infra-estruturais em áreas com ocupação condicionada ou com restrições específicas relacionadas com instabilidade de movimentos de massa, em sectores localizados em Banhos Secos e Copeira/Pereiros;

- da exposição infra-estrutural em áreas de ocupação condicionada ou com condicionantes específicas (nomeadamente resultantes de movimentos de massa), em certos sectores periféricos de Ceira e Sobral;

- da localização dos elementos edificados das povoações de Lagoas e Carvalhosas em áreas com Nível 2 de ocupação condicionada ou com restrições específicas, expressando a susceptibilidade a incêndios florestais e a movimentos de massa;

- de infra-estruturas rodoviárias, ferroviárias e de linhas de Muita Alta Tensão cruzadas em áreas com nível de ocupação condicionada ou com restrições específicas;

- de vulnerabilidade social em áreas de ocupação condicionada ou com restrições específicas em Pereiros, Vale de Cabras e Castelo Viegas;

\footnotetext{
${ }^{19}$ As áreas de restrição específicas reapresentam a expressão máxima de cada uma das perigosidades estudadas sendo a sua expressão cartográfica sempre sobreposta às vinculações anteriormente aferidas para o território.
} 
- de elevada exposição social no sector Conraria, Ceira, Vendas, Sobral e Bouça associada a áreas com ocupação condicionada e essencialmente com restrições específicas conjugando incêndios florestais e movimentos de massa ou cheias e inundações.

\section{Conclusões}

O estudo desenvolvido para testar a aplicação da lógica da perequação em áreas de potencial impacto de processos naturais perigosos, contribuindo assim para a gestão dos riscos, permite concluir, antes de mais, que as variáveis a utilizar para quantificar a vulnerabilidade social e os elementos expostos não devem ser estáticas, devendo haver sempre lugar a uma adaptação da metodologia a aplicar e dos elementos a equacionar em função de cada área de incidência dos instrumentos e da escala de análise.

Concluiu-se, igualmente que existe uma relação espacial e correlativa entre áreas de susceptibilidade crescente a processos naturais e as áreas mais valorizadas em função dos elementos expostos (na dimensão social e infra-estrutural).

$\mathrm{Na}$ área de estudo, salienta-se o aparecimento de espaços com elevada susceptibilidade relacionada com incêndios florestais, movimentos de massa em vertentes, cheias e inundações, o que levou a que se concluísse pela existência de contrastes e aptidões territoriais diferenciadas.

A análise da vulnerabilidade social, função das variáveis demográficas, grupos de riscos e funções sociais dos equipamentos, permitiu identificar espaços com graus de vulnerabilidade diferenciados em que a função social dos equipamentos supra-municipais assumiu importância determinante. A análise da componente da vulnerabilidade infra-estrutural fez realçar estruturas lineares, concentrações de edifícios habitacionais e alguns equipamentos de saúde e de educação. A análise conjunta dos perigos e da vulnerabilidade infra-estrutural permite concluir que existe algum ajustamento da ocupação e transformação do território em função do grau de susceptibilidade, existindo, porém, alguma a expansão urbana recente para áreas com graus superior de susceptibilidade.

A expressão da correlação entre a vulnerabilidade social e a perigosidade fez sobressair sectores em que as funções sociais de equipamentos, municipais ou supra-municipais, podem ser afectadas por processos de perigosidade de diferentes tipologias, existindo ainda aglomerados populacionais e grupos de risco expostos.

Tendo em consideração todos estes factores, a aplicação da lógica perequativa na gestão dos riscos na área de estudo consistiu na adopção de soluções diferenciadas, sob a forma de condicionantes ou restrições na gestão do território, para áreas territoriais expostas a diferentes perigos naturais e em diferentes graus, impondo critérios regulamentares diferenciados aos diferentes agentes (promotores, proprietários, municípios, e administração central), e incentivando práticas de prevenção e de redução do risco ou de comportamentos de auto-segurança.

Com efeito, a aplicação da metodologia perequativa na gestão dos riscos pressupõe partir das diferenças existentes no território e introduzir para as mesmas medidas de gestão (prevenção e redução do perigo, assim como a mitigação dos riscos) também diferenciadas que permitam tornar os territórios mais equitativos.

Conclui-se, deste modo, que a aplicação da lógica perequativa na gestão de riscos naturais deve ser assumida como componente do planeamento e da gestão do território numa óptica de prevenção, apresentando-se como um instrumento importante para o ordenamento e gestão territorial essencial para a promoção de uma cultura de segurança, e reconhecida pelos indivíduos e comunidades.

Em suma, conclui-se que a aplicação de medidas ou acções que dissuadam a ocupação, que incentivem práticas adequadas de redução do risco, que promovam adaptações estruturais ou não estruturais de aumento da resiliência do território e das populações, todas 
elas assentes numa lógica perequativa - isto é, com o intuito de introduzir uma "igualdade" entre os territórios sujeitos a processos naturais com consequências danosas para os seus "utilizadores" e o restante território não sujeito aos mesmos processos -, pode permitir e potenciar a redução da vulnerabilidade e do grau de exposição dos elementos instalados.

Jorge Miguel Marques de Brito

Câmara Municipal de Coimbra, Centro de Estudos Socais - Observatório do Risco OSÍRIS

Alexandre Oliveira Tavares

Faculdade de Ciências e Tecnologia , Centro de Estudos Socais, Universidade de Coimbra

Fernanda Paula Oliveira Faculdade de Direito da Universidade de Coimbra 


\section{RerCEDöUA}

\section{$>$ Doutrina}

"̈ 
RerCEDöUA 



\title{
Princípio da Precaução: Still Nothing New (Ou o in Dubio Pro Co-Incineração)
}

\author{
Comentário ao Acórdão do Supremo Tribunal Administrativo de 2 de Dezembro de 2009 \\ 1. a Subseccção do CA, Processo n.ำ0438/09
}

\section{Acórdão de 2 de Dezembro de 2009}

Assunto:

Incineração e co-incineração de resíduos perigosos.

\section{Acordam, na Secção do Contencioso Administrativo, do Supremo Tribunal Administrativo:}

A... e B..., identificados nos autos, requereram ao Tribunal Administrativo e Fiscal de Coimbra, contra o Ministério do Ambiente, do Ordenamento do Território e do Desenvolvimento Regional e a "C..." a adopção das seguintes providências cautelares:

1 - Suspensão de eficácia dos actos de concessão:

a) da licença ambiental, em 15.11.2006, pelo Presidente do Instituto do Ambiente, António Gonçalves Henriques à fábrica da C... de Souselas, denominada «Centro de Produção de Souselas» para a co-incineração de resíduos;

b) da licença de instalação, em 24.11.2006, pelo Vice-Presidente do Instituto dos Resíduos, Francisco Barracha, à fábrica da C... de Souselas denominada «Centro e Produção de Souselas» para a co-incineração de resíduos perigosos e não perigosos;

c) a licença de exploração nr. 2/2008/DOGR, em 24.01.2008, pela Sub-Directora Geral da Agência Portuguesa do Ambiente, Luisa Pinheiro, à fábrica da C... de Souselas, denominada «Centro de Produção de Souselas» para a co-incineração de resíduos perigosos;

2 - Intimação:

a) do Ministério do Ambiente, do Ordenamento do Território e do Desenvolvimento Regional para que se abstenha de atribuir novas licenças à fábrica da ... no Outão para o exercício da actividade de coincineração de resíduos perigosos enquanto estiver suspensa a eficácia das licenças supra-indicadas;

b) da C..., para que se abstenha de realizar testes ou demais operações de co-incineração de resíduos perigosos enquanto estiver suspensa a eficácia das licenças supra-indicadas.

Por sentença de 17-10-2008, o Tribunal Administrativo e Fiscal de Coimbra julgou improcedentes os pedidos formulados (Fls. 774/798)

Inconformados com tal decisão, os requerentes interpuseram recurso para o Tribunal Central Administrativo do Norte que, por acórdão de 12-02-2009, julgou procedente o recurso, deferindo o supra referido pedido de suspensão de eficácia (fls. 1008/1063).

É desta decisão que o Ministério do Ambiente, do Ordenamento do Território e do Desenvolvimento Regional e “C...” interpõem a presente revista a qual foi admitida por acórdão de 7-05-2009, (fls. 1263 a 1267).

A recorrente Cimpor formula as conclusões seguintes:

1. Considerada a indiscutível relevância social da questão da co-incineração e a circunstância de ter sido esta, ainda que indirectamente, o verdadeiro objecto do julgamento do TCA-N e não as licenças em si mesmas consideradas, forçosa se torna a intervenção do mais alto órgão de justiça administrativa, nos termos previstos no . $^{\circ} 1$ do art. $150 .^{\circ}$ do CPTA.

2. Suscita a Recorrente a intervenção do STA à semelhança do sucedido em sede do Recurso de revista n. ${ }^{\circ}$ 471/07, de 31 de Outubro de 2007, em que este Tribunal acordou revogar o acórdão do TCA-N que havia decidido temerariamente suspender o despacho do Ministro do Ambiente que dispensara, 
nos termos da lei, a realização de novo Estudo de Impacto Ambiental e do Recurso 675/07 (relativamente à co-incineração nas instalações da ... no Outão).

3. Com efeito, a manutenção da decisão do TCA-N, para além de não permitir resolver em tempo útil a questão relativa à destruição dos resíduos industriais perigosos, com todos os danos ambientais daí decorrentes, tem o efeito perverso de criar uma enorme confusão nas populações e na comunidade em geral quanto à legalidade da co-incineração, não sendo compreensível como é que o processo pode já ter estado suspenso, depois deixar de estar suspenso e agora vir a ser outra vez suspenso.

4. Por outro lado, e considerando especificamente o conteúdo material da decisão do TCAN objecto do presente recurso, cabe referir que nenhum dos critérios elencados pelo legislador no art. $120 .{ }^{\circ}$ do CPTA foi devidamente analisado por aquela instância, impondo-se a revogação do acórdão «sub judicio».

5. Assim, no que respeita à verificação do critério do fumus boni iuris, como o Tribunal considerou a priori que a matéria em causa era demasiadamente complexa, e exigiria prova mais aprofundada carecendo de ponderação e de maturação adicionais, acabou por se demitir totalmente da sua função e considerar preenchido o referido requisito legal, mesmo sem que nenhuma prova fosse efectuada.

6. Entende a Recorrente não ser de admitir tal conduta, na medida em que, por mais que o critério legal apenas se reporte ao facto de não ser manifesta a falta de fundamento da pretensão formulada (anulação dos actos administrativos), a verdade é que a não ilegalidade apenas não é manifesta se houver alguma prova concreta e objectiva que milite no sentido da sua provável ilegalidade, devendo essa prova ser analisada e ponderada pelo Tribunal, que a ela se deverá reportar na sentença.

7. A aceitar-se como boa aquela aplicação do Direito, então o requisito do fumus boni iuris estaria sempre preenchido ex officio (dispensando qualquer intervenção do Requerente da providência).

8. Nestes termos, não podia o Tribunal ter considerado provado, no caso em apreço, o requisito do fumus boni iuris (mesmo que na versão aligeirada do fumus non malus iuris) por não ter sido identificada qual a prova, ainda que indiciária, que o levou a considerar que a aprovação dos três actos administrativos suspendendos pode ser ilegal e, como tal, que não é manifesto que os mesmos não venham a ser anulados no fim do processo principal.

9. Pelo contrário, na ausência de quaisquer indícios da ilegalidade dos actos em crise, seria forçoso que o Tribunal considerasse não provado o requisito do fumus boni iuris e como tal indeferisse a providência cautelar.

10. Mais cabe referir que não saem estas conclusões prejudicadas pela temerária, equívoca e abusiva invocação do princípio da precaução que não se sabe ao certo se foi ou não utilizado.

11. Por outro lado, também relativamente à aplicação do critério do periculum in mora procedeu o TCA-N a uma incorrecta aplicação da lei, na medida em que, ao invés da prova e demonstração dos factos integradores dos pressupostos ou requisitos em questão, bastou-se o Tribunal precisamente com aquilo que havia dito não bastar, ou seja com a utilização de expressões vagas e genéricas.

12. Com efeito, no elenco dos factos provados, mesmo depois de ampliada a matéria de facto, não se encontram quaisquer factos que sejam hábeis para provar a existência de periculum in mora.

13. Assim, o Tribunal, ao querer, contra tudo e contra todos, considerar que se estava perante uma situação de facto consumado, acabou por falhar duplamente.

14. Em primeiro lugar, não logrou encontrar quaisquer factos que fossem prestáveis para demonstrar que a co-incineração provoca danos na saúde e no ambiente, razão pela qual teve de concluir - de modo infeliz - dizendo que, "não obstante se possa e deva entender que está em causa matéria de cariz essencialmente técnico e por isso sujeita a prova pericial, entendemos que a dúvida existente sobre os riscos aqui em causa tal como foram definidos na causa de pedir justifica que se valorize essa dúvida de forma a julgar verificado o requisito do periculum in mora, por estarem em causa prejuízos plausíveis de difícil reparação".

15. Em segundo lugar, a situação em causa, mesmo a ocorrer, nunca configuraria, como o STA aliás já disse em sede de Recurso n. ${ }^{\circ}$ 471/07 de 31 de Outubro de 2007, uma situação de facto consumado, como erradamente a qualificou o Tribunal a quo.

16. Em suma, nem foi feita prova no sentido de demonstrar que a execução dos despachos pudesse provocar danos na saúde e no ambiente, nem a ocorrência desses mesmos danos (a existirem) criaria uma situação de facto consumado que não pudesse ser revertida no final da "acção principal".

17. Finalmente, nunca a licença de instalação e a licença ambiental seriam actos capazes, na medida em que não são o último acto no final do procedimento, para provocarem qualquer violação no ambiente ou na saúde. 
18. Por último, chegados à ponderação de interesses exigida pelo $n .^{\circ} 2$ do art. $120 .^{\circ}$ do $\mathrm{CPTA}$, veio o TCA-N a quo deixar clara a ideia, que já se vinha a sedimentar, de que, neste domínio, usa, claramente, "dois pesos e duas medidas".

19. Na realidade, não deixa de ser inquietante que o Tribunal a quo tenha considerado que os eventuais e não provados danos no ambiente provocados pela co-incineração pudessem (na dúvida) constituir uma situação de facto consumado e depois considere, displicentemente, que os danos reais e provados relativos ao "passivo ambiental" (que não são contestados por ninguém), não só não constituam uma situação de facto consumado como ainda é aceitável (para o Tribunal) que esta situação possa continuar por mais algum tempo até à decisão do processo principal.

20. É, assim, completamente infundada a conclusão do Tribunal, quando considera que os danos causados com a recusa da providência são superiores aos danos causados com a sua concessão.

21. Na verdade, não conseguiu o Tribunal demonstrar minimamente, nem a superioridade de uns (alegados) danos ambientais e sobre a saúde face a outros (alegados) danos ambientais e sobre a saúde, nem tão pouco logrou demonstrar porque é que num caso considerou que (na dúvida) havia uma situação de facto consumado e no outro caso considerou (sem qualquer dúvida e sem querer ouvir as testemunhas arroladas) que não tinha sido feita prova dos danos.

0 recorrente MAOTDR formula as seguintes conclusões:

1. As questões suscitadas no processo em apreço, pela sua relevância social e jurídica, e sua importância fundamental, e a necessidade de melhor aplicação do direito, impõem a admissão do presente recurso de revista.

2. A douta decisão em apreço é manifestamente ilegal, é contrária, à Jurisprudência do Supremo Tribunal e, pelas suas consequências negativas, deve ser imediatamente revogada.

3. Relativamente ao pedido de suspensão dos actos de licenciamento da instalação e ambiental, não pode ter-se por verificado o periculum in mora, pois tais actos intercalares de licenciamento não são susceptíveis de constituir uma situação de facto consumado ou prejuízos de difícil reparação, pelo que o decretamento daquelas providências violou o artigo $120^{\circ}, \mathrm{n}^{\circ} 1$, al. b) do CPTA.

4. A douta decisão recorrida, ao admitir uma providência cautelar que depende de duas causas principais, fez errada interpretação e aplicação do disposto nos artigos $112^{\circ}, n^{\circ} 1,113^{\circ}, n^{\circ} 1$ e 3 e $114^{\circ}$, $\mathrm{n}^{\circ} 3$, al. e) do CPTA.

5. E ao decretar, apesar disso, a suspensão da licença de exploração, cuja anulação não vem pedida na acção principal, o douto acórdão violou os artigos $112^{\circ}, n^{\circ} 1,113^{\circ}, n^{\circ}-51,2$ e 3 e $120^{\circ}, n^{\circ} 1$, al. b) do CPTA.

6. A douta decisão fez errada interpretação e aplicação do conceito "constituição de situação de facto consumado", pelo que ao aplicar tal conceito à verificação do periculum in mora, violou o disposto no artigo $120^{\circ}, \mathrm{n}-1$, al. b) do CPTA.

7. $O$ acórdão recorrido, ao aplicar à verificação do periculum in mora um alegado princípio da precaução, que não tem consagração na ordem jurídica, fez errada interpretação e aplicação do artigo $174^{\circ}$ do Tratado da CE, do artigo $66^{\circ}, n^{\circ}$ 2, al., a) da CRP, do artigo $3^{\circ}$, al. a) da Lei de Bases do Ambiente e, mais uma vez, do artigo $120^{\circ}, n^{\circ} 1$, al. b) do CPTA.

8. Ao entender haver lugar à inversão do ónus da prova da ocorrência de prejuízos de difícil reparação, fez a decisão recorrida errada interpretação e aplicação do disposto no artigo $174^{\circ}$ do Tratado da CE, no artigo $66^{\circ}$, no 2, al. a) da Constituição, no artigo $3^{\circ}$, al. a) da Lei de Bases do Ambiente, bem como nos artigos $342^{\circ}, n^{\circ} 1,483^{\circ}, n^{\circ} 2$ e $487^{\circ}$, no 1 do Código Civil.

9. E sempre a decisão recorrida, ao abster-se de apurar se os dados científicos recentes justificavam o recurso ao princípio da precaução, teria feito uma deficiente leitura do referido princípio. 10. Ao afastar da ponderação de interesses os prejuízos alegados pelo requerido relativos aos danos no ambiente e na saúde pública, a decisão impugnada fez errada aplicação dos artigos $64^{\circ}$ e $66^{\circ}$ da CRP, bem como do artigo $120^{\circ}, \mathrm{n}^{\circ} 2$ do CPTA.

11. E, relativamente ao alegado passivo ambiental, o douto acórdão, ao considerar não ter o recorrente feito prova da existência de tal passivo, violou o artigo $118^{\circ}, n^{\circ}-52$ e 4 do CPTA, bem como o princípio da inquisitoriedade na averiguação da verdade material, constante do $n^{\circ} 3$ do mesmo artigo $118^{\circ}$.

10. E, pelos mesmos motivos, foram igualmente violados o direito ao ambiente e à saúde, consagrado nos artigos $64^{\circ}$ e $66^{\circ}$ da Constituição.

13. Ao ter feito recair unicamente sobre o recorrente o ónus de provar os prejuízos para os interesses ambientais e de defesa da saúde pública por ele invocados, o acórdão em apreço violou também o artigo $114^{\circ}, \mathrm{n}^{\circ} 3$, al. g) do CPTA, bem como o artigo $120^{\circ}, \mathrm{n}^{\circ} 2$ do mesmo Código. 
11. E violou ainda, pelo mesmo motivo, o princípio da igualdade das partes, consagrado no artigo $6^{\circ}$ do CPTA, bem como o direito a um processo equitativo, ou seja, o direito à tutela judicial efectiva consagrado no artigo $20^{\circ}$ da CRP.

12. Ao ter decidido que os danos que resultariam da recusa da providência eram superiores aos que resultariam da sua concessão, o tribunal a quo fez errada interpretação e aplicação do artigo $120^{\circ}$, $\mathrm{n}^{\circ} 2$ do CPTA.

13. Ao ter omitido a pronúncia sobre o pedido de intimação, a mesma decisão interpretou erradamente o alcance das consequências do decretamento da suspensão das licenças, e violou assim o artigo $668^{\circ}, n^{\circ} 1$, al. d) do CPC, o que acarreta a sua nulidade, por omissão de pronúncia.

14. A entender-se ser o pedido de intimação relativo à atribuição de licenças à fábrica da $\mathrm{C}$... em Souselas, então foi violado o princípio do contraditório, constante do artigo $3^{\circ}, \mathrm{n}^{\circ} 3$ do CPC, bem como o princípio da igualdade das partes consagrado no artigo $6^{\circ}$ do CPTA.

Os recorridos A... e B..., contra alegaram formulando as conclusões seguintes:

1 - $O$ recorrente Ministério do Ambiente, fundamentou o presente recurso excepcional de revista na «relevância social do tema» co-incineração de resíduos industriais perigosos (RIP’s).

2 - «Dada a sua relevância social é de admitir a revista em que as questões jurídicas a dirimir se relacionam com uma matéria particularmente sensível em termos do seu impacto comunitário» - Ac. do STA de 26.06.2008 proferido no proc. nr. 535/08, disponível em

http://www.dgsi.pt/jsta.nsf/35fbbbf22e1bb1e680256f8eo03ea931/8ddf2f580c867f4d80257481 00306711?OpenDocument

3 - A relevância social do tema é absolutamente irrelevante (passe a redundância) se não forem indicadas questões concretas que, pela sua relevância jurídica ou social, se revista ou revistam de importância fundamental, ou seja, em que se verifique existir «complexidade das operações lógicas implicadas pela questão a resolver e a probabilidade de esta se renovar em litígios futuros» - Ac. do STA de 22.03.2007 - Proc. 223/07.

4 - Mesmo que se considere que «A necessidade de eliminação de resíduos industriais perigosos afecta toda a população, sendo premente a questão do tratamento a dar àqueles resíduos», conforme se alega na pág. 2 da alegação do MA, nem por isso se poderá concluir que a inegável relevância social fundamental de tal questão justifica, de per si, a admissão do presente recurso.

5 - Acresce que não esteve (nem está) em causa no presente processo a apreciação da questão da co-incineração dos Resíduos Industriais Perigosos (RIPs), mas sim a da suspensão ou não da eficácia das licenças ambiental, de instalação e de exploração concedidas para a co-incineração de resíduos industriais perigosos, concretamente, na fábrica de cimento da C....

6 - Aliás o Tribunal a quo deixou claro que não lhe compete aferir «da oportunidade da solução de co-incineração» (pág. 39 do douto Acórdão recorrido).

7 - Em suma: para poder ser admitido o recurso excepcional de revista para o STA previsto no artigo 150 1. do CPTA é necessário que esteja em causa a apreciação de pelo menos uma questão concreta (e não a emissão de um parecer sobre determinado tema) que tenha sido decidida, ou relativamente à qual tenha havido omissão de pronúncia, pelo tribunal recorrido e que, pela sua relevância jurídica ou social, se revista de importância fundamental ou quando a admissão do recurso seja claramente necessária para uma melhor aplicação do direito

8 - Ao alegar que «importará uma pronúncia» do STA sobre:

a) «a consagração legal na nossa ordem jurídica do denominado princípio da precaução, bem como da inversão do ónus da prova da ocorrência de danos, na falta de norma legal que expressamente 0 preveja, quando sejam invocados prejuízos para o ambiente ou para a saúde pública»;

b) a definição.., do conteúdo do conceito de constituição de uma situação de facto consumado», está o recorrente MA a pretender que o Tribunal ad quem emita pareceres sobre duas questões gerais de direito, ou seja, que esclareça se o princípio da precaução tem ou não consagração legal na nossa ordem jurídica e, em caso afirmativo, se implica a inversão do ónus da prova da ocorrência de danos, quando sejam invocados prejuízos para o ambiente ou para a saúde pública e também que defina o conceito de constituição de uma situação de facto consumado.

9 - Ora, conforme resulta do Acórdão do STA de 22.10.2008, proferido no proc. nr. 0396/08 da $2^{\underline{a}}$ subsecção do contencioso administrativo, disponível em http://www.dgsi.pt/jsta.nsf/35fbbbf22e1b b1e680256f8eo03ea931/d7071eoc3afo3750802574f100421b3d?OpenDocument «o recurso de revista excepcional previsto no arto $150^{\circ}$ do CPTA é ainda o recurso de uma decisão judicial e não um meio 
de obtenção de pareceres sobre questões gerais de direito, ainda que de relevância social, mas que não relevam para a concreta decisão do processo, uma vez que o STA não tem funções consultivas».

10 - O recorrente MA limita-se pois a solicitar a pronúncia do STA sobre duas questões gerais de direito.

11 - Acresce que o Acórdão recorrido nem sequer aplicou no caso em apreço o princípio da precaução, consagrado no art. $66^{\circ}$ 2. al. a) da CRP e no art. $174^{\circ}$ 2. do Tratado da União Europeia e a consequente inversão do ónus da prova a que aludiu a pág.s 42/43.

12 - Ao contrário do sustentado pelo recorrente MA na pág. 3 da sua alegação a admissão do presente recurso não é «claramente necessária para uma melhor aplicação do direito», pois inexiste o «clamoroso erro de julgamento» que, segundo aquele recorrente, «se traduz em admitir uma providência cautelar que depende de duas causas principais».

13 - «Nada impede o decretamento de uma providência cautelar que dependa de mais de uma causa principal» - pág. 51 do douto Acórdão recorrido.

14 - Quando foi instaurada em 4.05.2007 a acção principal - proc. nr. 364/07.5BECBR, em que foram impugnados os actos de concessão das licenças ambiental de 15.11.2006 e de instalação de 24.11.2006, ainda não tinha sido praticado o acto de concessão em 24.01.2008 da licença de exploração nr. 2/2008/DOGR ( $3^{\circ}$ acto suspendendo), que foi por tal motivo impugnado na $2^{2}$ acção principal - proc. nr. 641/08.0BECBR, razão pela qual a presente acção cautelar foi instaurada como preliminar da acção principal (interposta em 23.06.2008) a que corresponde o proc. nr. 641/o8.0BECBR e como incidente da acção principal a que corresponde o processo $\mathrm{nr}$. 364/07.5BECBR, tendo sido requerida em 12.08.2008 a apensação à acção principal da $2^{\underline{a}}$ acção principal (doc. 1 anexo), não podendo ser imputado aos recorridos o facto de não ter sido ainda proferida decisão sobre essa questão, que contudo é irrelevante na presente acção cautelar pela razão apontada na conclusão anterior

15 - O presente recurso excepcional de revista interposto pelo recorrente Ministério do Ambiente carece de fundamento legal, dado o não preenchimento dos requisitos de admissibilidade impostos pelo art. $150^{\circ}$ 1. do CPTA, pelo que deverá ser rejeitado.

16 - É falso que a questão em apreço nos presentes autos já tenha sido apreciada pelo STA no processo $n^{\circ}$ 471/o7 do STA uma vez que nesse processo esteve em causa a suspensão ou não da eficácia do despacho do Ministro do Ambiente que dispensou a C... da Avaliação de Impacte Ambiental para a co-incineração de resíduos industriais perigosos (RIP's) na fábrica da C... de Souselas, enquanto que no presente processo está em causa a suspensão ou não da eficácia das licenças ambiental, de instalação e de exploração para a co-incineração de RIP's naquela fabrica da C....

17 - É também falso que «os Senhores Desembargadores para darem como verificado o periculum in mora» tenham ignorado «em absoluto as normas do processo» e tenham dispensado os requerentes «de qualquer prova da verificação daquele requisito» - pág. 5 da alegação do MA, tendo, bem pelo contrário, considerado que «numa providência cautelar vigora também a regra geral do ónus da prova, segundo a qual àquele que invoca um direito cabe fazer a prova dos factos constitutivos do mesmo artigo $342^{\circ}$ 1, do Código Civil. Só que, no âmbito cautelar, o legislador basta-se com uma prova sumária dos fundamentos do pedido» pág. 42 do douto Acórdão recorrido).

18 - Alude o recorrente MA na pág. 7 da sua alegação que as licenças ambiental e de instalação são «actos intercalares dum procedimento» e só a licença de exploração constitui «o acto final do mesmo».

19 - Nenhum dos 3 actos suspendendos poderá ser considerado acto intercalar do procedimento já que cada um deles culmina o respectivo processo de licenciamento e estão numa relação de interdependência (conforme resulta dos n.s 1. e 2. do artigo do Dec. Lei 85/2005 de 28.04, com a redacção que the foi dada pelo art. $79^{\circ}$ do Dec. Lei $178 / 2006$ de 5.09), só podendo ser concedida a licença de exploração para a co-incineração de RIP's depois de terem sido emitidas as licenças ambiental e de instalação para o mesmo fim, sendo, pois, estas duas licenças conditio sine qua non da concessão daquela licença de exploração.

20 - O recorrente MA impugnou, no Capítulo II e seguintes da sua alegação, o douto Acórdão recorrido como se existisse um duplo grau de recurso jurisdicional e se tratasse de um recurso ordinário.

21- Contrariamente ao sustentado pelo MA na pág. 8 da sua alegação, o douto Acórdão recorrido não só não violou «o disposto no artigo $120^{\circ}, \mathrm{n}^{\circ}$ 1, al. b) do CPTA», como fez aliás uma exemplar aplicação dessa norma.

22 - Apesar de o recorrente MA ter reconhecido na pág. 12 da sua alegação que «o tribunal recorrido entendeu que se verificava o periculum in mora, nas suas variantes de constituição de uma situação de facto consumado, e da existência de prejuízos de difícil reparação», não incluiu no rol das questões 
jurídicas a apreciar pelo STA que, em seu entender, «se revestem de inegável importância, extravasando o caso concreto» (pág. 3 da sua alegação), a do fundado receio da produção de prejuízos de difícil reparação, mas tão só a relativa à definição de constituição de uma situação de facto consumado, pelo que se terá de concluir que a impugnação que faz no Capítulo V da sua alegação à parte do Acórdão recorrido que considera «verificado o requisito do periculum in mora, por estarem em causa prejuízos plausíveis de difícil reparação»- pág. 45, não preenche os requisitos impostos pelo art. $150^{\circ}$ do CPTA para o presente recurso excepcional de revista, traduzindo-se numa forma de impugnação imprópria e inadmissível no presente contexto processual

23 - Quanto à questão da definição de constituição de uma situação de facto consumado é por demais evidente que o recurso excepcional de revista previsto no art. $150^{\circ} 1$, do CPTA não serve para levar o STA a clarificar este ou aquele conceito jurídico, mas sim para apreciar questão ou questões concretas que, pela sua relevância jurídica ou social, se revista ou revistam de importância fundamental e que tenha $(\mathrm{m})$ sido decidida(s), ou relativamente à qual ou quais tenha havido omissão de pronúncia, pelo tribunal recorrido.

24 - Como é também evidente que os danos resultantes para a saúde pública e para o meio ambiente dos Poluentes Orgânicos Persistentes que se produzem e libertam durante as operações de co-incineração de resíduos perigosos, que se viessem a realizar caso não tivesse sido suspensa a eficácia das licenças que as autorizam, seriam irreversíveis, não podendo como é óbvio ser evitados a posteriori através de uma sentença favorável aos recorridos, proferida na acção principal.

25 - Ao sustentar na pág. 46 do Acórdão de 12.02.2009 que «existe, pois, um risco fundado de constituição de uma situação de facto consumado por haver fundado receio de que se a providência for recusada se tomará impossível a reintegração no plano dos factos da situação conforme à legalidade uma vez decidido o processo principal com decisão favorável à pretensão do requerente cautelar», está o tribunal a quo a fazer uma interpretação correcta do conceito legal de «fundado receio da constituição de uma situação de facto consumado», tendo em consideração os factos dados por provados nas pág.s 34 e 45 do douto Acórdão recorrido e nos artigos 40 a 44, 77, 78, 80 e 81 do requerimento inicial para os quais remete o douto Acórdão recorrido - pág 45.

26 - Mesmo que assim não fosse, o que só por hipótese meramente académica se admite, sempre permaneceria inabalável o fundado receio da produção de prejuízos irreversíveis ou, na melhor das hipóteses, de difícil reparação, reconhecido pelo douto Acórdão recorrido - pág. 45.

27 - Ao contrário do sustentado pelo MA (pág. 15 da sua alegação), o princípio da precaução «tem consagração constitucional» - $\operatorname{artigo} 66^{\circ}$ 2. a) da Constituição, estando os

Estados-membros da União Europeia vinculados ao cumprimento do Tratado da União Europeia que no seu artigo $174^{\circ}$ consagra tal princípio.

28 - Mesmo que se considerasse que o princípio da precaução teria sido aplicado pelo Tribunal a quo no caso sub judice (o que não foi o caso), ainda assim se teria de concluir não ter sido minimamente determinante da decisão em apreço, visto esta assentar fundamentalmente nos factos indicados a pág.s 34 e 45 do douto Acórdão recorrido e não no facto (nunca mencionado) de os recorrentes não terem feito prova de que a co-incineração de RIP's não implicaria qualquer risco para a saúde pública ou para o meio ambiente.

29 - Determinante para a decisão recorrida foram também os factos invocados «nos artigos 40 a 44 da petição» para os quais remete o douto Acórdão recorrido de 12.02.2009 (pág. 45), nomeadamente, a situação geográfica de Souselas «já que a cimenteira está em cima da população de Souselas e a 4,5 Km de Coimbra» (pág. 45 do douto Ac. recorrido) ; o facto de a queima de resíduos perigosos se fazer por conseguinte «no meio da população de Souselas e ao lado da cidade de Coimbra» (art. $40^{\circ}$ da petição inicial); as condições geográficas de Coimbra «que potenciam a concentração de substâncias poluentes sobretudo durante a noite e madrugada» (art. $41^{\circ}$ da petição inicial), o que se traduz na «existência de um risco de concentração de poluentes susceptíveis de aumentar o risco de contrair certas doenças por parte de quem vive nas proximidades de uma cimenteira em co-incineração de resíduos perigosos, nomeadamente face à situação critica, desde logo, da cidade de Coimbra» (pág. 45 do douto Ac. recorrido); doenças essas que são a «asma, bronquite crónica, alergias, diabetes e tensão arterial elevada» art. $42^{\circ}$ da petição inicial) e ainda «doenças respiratórias, cardíacas, endócrinas, tumorais» (art. $43^{\circ}$ da petição inicial).

30 - Como determinante foi ainda o facto alegado no art. $112^{\circ}$ do requerimento inicial e não impugnado de que «a fábrica da C... não está dotada de mecanismos de monitorização capazes de 
aferir da qualidade do ar envolvente da região e ainda que nada foi feito sobre a prévia caracterização detalhada das condições ambientais apontadas pelo Grupo de Trabalho Médico (art.s 77, 78, 80 e 81 da petição)» - pág. 45 do douto Acórdão recorrido.

31 - Não menos determinantes foram os doutos Pareceres da Quercus e dos médicos ... e ... e bem assim o Relatório da autoria do Professor Doutor ..., a que se alude, nas alíneas J), L) e M) da matéria de facto dada por provada - pág. 34 do douto Acórdão recorrida, que não deixam margem para dúvidas quanto à elevadíssima perigosidade para a saúde pública e para o meio ambiente dos Poluentes Orgânicos Persistentes, nomeadamente das dioxinas e dos furanos, que resultam inevitavelmente da co-incineração de resíduos industriais perigosos.

32 - 0 artigo 5ำ da Convenção de Estocolmo, aprovada pelo Decreto 15/2004, publicado no Diário da República 1 Série de 3.06.2004 e que entrou em vigor em Portugal em 13 de Outubro de 2004, consagra medidas para reduzir ou eliminar as libertações derivadas da produção não intencional de Poluentes Orgânicos Persistentes (POP, «com o objectivo da sua continuada minimização e, quando possível, da sua efectiva eliminação», enquanto que na Parte II do Anexo C daquela «Convenção sobre Poluentes Orgânicos Persistentes» se refere que «As dibenzeno-p-dioxinas policloradas e os dibenzofuranos policlorados ... são formados de modo não deliberado e libertados por processos térmicos que envolvem matéria orgânica e cloro em resultado de uma combustão incompleta ou de reacções químicas.», indicando-se na respectiva alínea b) os «Fornos de cimento que queimem resíduos perigosos», como uma das fontes industriais que «têm potencial para a formação e libertação comparativamente elevadas» das supra-referidas substâncias, o que contraria o sustentado pelo recorrente MA na pág. 17 da sua alegação quando se refere às Guidelines da Convenção de Estocolmo, aprovadas no Uruguai de 2 a 6 de Maio de 2005, que obviamente não podem apontar no sentido contrário ao indicado pela Convenção que visam interpretar.

33 - Mais do que o risco cientificamente comprovado para a saúde humana, para a fauna e para a flora, resultante dos POP's - Poluentes Orgânicos Persistentes que se formam durante a combustão dos resíduos industriais perigosos, existe a certeza consagrada pela Convenção de Estocolmo, subscrita por 119 Países, da grande perigosidade inerente à disseminação das dibenzeno-p-dioxinas policloradas e dos dibenzo-furanos policlorados, vulgo dioxinas e furanos.

34 - Da co-incineração de resíduos industriais perigosos resultam pois substâncias muito mais perigosas do que aquelas que são submetidas àquele processo de queima e que alguns pensam poder eliminar, esquecendo o velho princípio de Lavoisier, químico francês do século XVIII (curiosamente também licenciado em Direito), segundo o qual «na natureza... nada se perde, tudo se transforma».

35 - Carece pois totalmente de fundamento a afirmação de que o Tribunal a quo terá baseado «a verificação do requisito do periculum in mora na existência legal do denominado princípio da precaução em matéria do ambiente, e na inversão do ónus da prova dos prejuízos» - pág. 18 da alegação do MA.

36 - É duplamente errada a afirmação, que integra a pág. 18 da alegação do MA, de que «a decisão recorrida ... teria feito uma deficiente leitura do próprio princípio que quis aplicar», pois, por um lado, foi correcta a interpretação feita do princípio da precaução pelo douto acórdão recorrido e por outro porque o acórdão em apreço não «quis aplicar» tal princípio.

37 - Para além de ser ridícula a questão abordada no Capítulo VII da alegação do MA, ela traduz-se numa tentativa de negação da evidência, pois é manifesto o lapso resultante da troca da fábrica da C... de Souselas pela da ... do Outão, desde logo pelo facto de que a competência territorial do Tribunal Administrativo e Fiscal de Coimbra nunca lhe permitiria pronunciar-se sobre o pedido de decretamento da providência cautelar de intimação do MA para que se abstivesse de atribuir novas licenças a uma fábrica situada em Outão - Setúbal.

38 - Decidiu bem o Tribunal recorrido ao ter considerado que o conhecimento do pedido de intimação para que o MA se abstenha de atribuir novas licenças à fábrica da C... de Souselas para o exercício da actividade de co-incineração de resíduos perigosos, enquanto estiver suspensa a eficácia das licenças ambiental, de instalação e de exploração, «fica prejudicado já que o conteúdo do mesmo está absorvido pelas consequências do provimento do pedido cautelar» - pág 52 do douto Acórdão recorrido, o que revela que não se verificou a imputada omissão de pronúncia relativamente a tal pedido, reconhecendo os recorridos que nem sequer precisavam de ter formulado esse pedido no requerimento inicial, uma vez que o impedimento da concessão de novas licenças para a co-incineração de RIP's é uma consequência inerente à adopção da providência cautelar de suspensão das 3 licenças cuja validade e eficácia é indispensável para o legal processamento da co-incineração de resíduos perigosos. 
39 - O recorrente MA continuou, nos Capítulos VII e VIII da sua alegação, a impugnar o Acórdão recorrido como se de um recurso ordinário se tratasse, não se cingindo às três questões que apontou no Capítulo 1, cuja importância considera extravasar «as meras relações entre as partes, projectandose num número indeterminado de cidadãos, na sua saúde, e no ambiente, em geral»- pág. 2 da sua alegação, atacando o douto Acórdão recorrido «a torto e a direito», o que contraria o disposto no art. $150^{\circ}$ do CPTA.

40 - Nenhuma razão assiste ao recorrente MA quando sustenta no Capítulo VIII da sua alegação que «Os Mtos. Juízes não procederam à ponderação dos interesses em presença... com o argumento de que o ora recorrente não fez prova dos prejuízos para os interesses públicos por si defendidos» pág. 23), abordando assim mais uma questão que não se identifica com qualquer das três que enunciou no Capítulo 1 da sua alegação e que são aquelas em que fundamenta o seu recurso excepcional de revista.

41- 0 Tribunal recorrido ponderou os factos invocados pelo recorrente «atinentes à demonstração dos alegados prejuízos para o interesse público decorrentes da concessão da providência» (pág. 5 da alegação do MA), como resulta das pág.s 48 e 49 do douto Acórdão recorrido, tendo porém concluído (e bem) que uos danos causados com a recusa da providência são superiores aos danos causados com a sua concessão» (pág. 50).

42 - Dentre os diversos interesses públicos invocados pelo MA só de facto o da eliminação de um pretenso passivo ambiental tem «dignidade constitucional», pelo que também nesta matéria decidiu bem o Tribunal a quo - pág. 49 do douto Acórdão recorrido.

43 - É por demais evidente que ponderados os interesses em presença, atenta a matéria de facto dada por provada (nas pág.s 21 a 23, 34 e 45 do douto Acórdão recorrido e nos artigos 40 a 44, 77, 78,80 e 81 do requerimento inicial para os quais remete o douto Acórdão recorrido - pág 45), tendo em consideração que nenhum dos estudos favoráveis à co-incineração referem «a existência de qualquer dano na saúde pública e no ambiente, resultante da inexequibilidade imediata dos actos de co-incineração, isto é, até à decisão da acção principal a que corresponde este meio cautelar» pág. 50 do douto Acórdão recorrido) ter-se-á de concluir que decidiu bem o Tribunal a quo ao ter concluído que «os danos causados com a recusa da providência são superiores aos danos causados com a sua concessão» - pág. 50 do douto Acórdão recorrido.

44 - «Constitui matéria de facto de que o Supremo não conhece em recurso de revista, fora das situações tipificadas na 2 parte do $n^{\circ} 4$, do art. $150^{\circ}$ do CPTA, o juízo feito pelo TCA quanto à existência de prejuízos e à ponderação de interesses prevista no $\mathrm{n}^{\circ} 2$, do art. $120^{\circ}$ do citado Diploma Legal»- Ac. do STA de 22.01.2009, proferido no proc. nr. 24/09 e disponível em http://www.dgsi.pt/jsta.nsf/35fbbb f22e1bb1e680256f8eo03ea931/cb285dfccdf4fe088025754c0041c226?OpenDocument no mesmo sentido o Ac. do STA de 2.10.2008, proferido no proc. nr. 776/o8 e disponível em http://www.dgsi.pt/jsta. nsf/35fbbbf22elbb1e680256f8eo03ea931/ea2a017a285302e9802574de0030509b?OpenDocument

45 - Carece de fundamento o invocado pelo MA na pág. 28 da sua alegação de que «o douto tribunal recorrido...considerou que o recorrente não havia feito prova da existência de quaisquer prejuízos para o interesse público que adviriam da concessão das providências», pois não só não comporta o douto Ac. recorrido uma tal consideração, como inclusive são enunciados nas pág.s 48 e 49 do Acórdão de 12.02.2009 os interesses públicos invocados pelo recorrente MA, pelo que não foi por falta de prova dos interesses invocados pelo recorrente MA que o Tribunal a quo decidiu pela prevalência dos interesses invocados pelos recorridos.

46 - 0 n. ${ }^{\circ} 3$ do art. $118^{\circ}$ do CPTA não impõe ao Juiz que ordene as diligências de prova requeridas, mas tão só as que "considere necessárias».

47 - Só haveria violação do disposto no art. $118^{\circ}$ 2. 3. e 4. do CPTA se o Tribunal a quo tivesse impedido a realização da prova testemunhal e depois decidisse que a prova não foi efectuada, penalizando assim a parte que ofereceu tal meio de prova, o que não foi manifestamente o caso.

48 - Ao contrário do sustentado pelo recorrente MA na pág. 29 da sua alegação, não fez o Tribunal recorrido interpretação e aplicação errada da norma que integra a alínea g) do nr. 3 do art. $114^{\circ}$, nem do art. $120^{\circ}$ 2. do CPTA, como não violou o princípio da igualdade das partes, consagrado no art. $6^{\circ}$ do CPTA, nem o princípio da igualdade de armas e da tutela efectiva (art. $20^{\circ}$ da CRP).

49 - Contrariamente ao sustentado pela recorrente C... na pág. 3 da sua alegação «o que foi a julgamento», não foi «a questão da co-incineração», mas sim a questão da suspensão ou não da eficácia das licenças ambiental, de instalação e de exploração para a co-incineração de resíduos perigosos em concreto na fabrica da C... de Souselas, o que é bem diferente. 
50 - É absolutamente irrelevante, no presente contexto processual, a questão da co-incineração de resíduos perigosos enquanto tal, uma vez que essa questão não foi objecto de decisão por parte do douto Acórdão recorrido, que inclusive deixou claro que não lhe compete aferir «da oportunidade da solução de co-incineração» (pág. 39 do douto Acórdão recorrido).

51 - Aludindo apenas na pág. 3 da sua alegação à «indiscutível relevância social» da «questão da co-incineração» a recorrente $C$... recorreu e alegou como se dispusesse de um duplo grau de recurso jurisdicional e de um recurso ordinário se tratasse, não tendo indicado uma única «questão que, pela sua relevância jurídica ou social, se revista de importância fundamental» e devesse por isso ser apreciada pelo STA, nem tendo invocado que a admissão do presente recurso seria «claramente necessária para uma melhor aplicação do direito», pelo que deve ser rejeitado o seu recurso extraordinário de revista, por falta de preenchimento dos requisitos de admissibilidade definidos no art. $150^{\circ}$ do CPTA.

52 - A recorrente $C$... fundamenta o seu recurso excepcional de revista no facto de «estar em causa uma relevante questão social de importância fundamental» com referência à

co-incineração de resíduos perigosos (pág. 5 da sua alegação), tendo assim inventado mais uma competência para o STA: a da apreciação de questões sociais em recurso excepcional de revista.

53 - Não faz qualquer sentido a afirmação que consta da pág. 7 da alegação da recorrente C... de que o tribunal recorrido «está, no fundo, a dizer que em matéria de verificação do requisito de fumus boni iuris não é preciso haver sequer uma réstia de prova de fumus», uma vez que no douto Acórdão recorrido se proclama (pág. 42) que «numa providência cautelar vigora também a regra geral do ónus da prova, segundo a qual àquele que invoca um direito cabe fazer a prova dos factos constitutivos do mesmo artigo $342^{\circ}$ 1. do Código Civil. Só que, no âmbito cautelar, o legislador basta-se com uma prova sumária dos fundamentos do pedido».

54 - «Para apreciar se, na esfera do requerente, se preenchem ou não os requisitos do periculum in mora e do fumus boni iuris (ou do fumus non malus iuris), o tribunal não procede a juízos definitivos, que apenas cumpre realizar no processo principal, mas a apreciações perfunctórias, baseadas em juízos sumários sobre os factos a apreciar» - Mário Aroso de Almeida e Fernandes Cadilha, CPTA Anotado, 2 ed. 2007 pág. 711.

55 - «O mesmo parece valer para a apreciação do periculum in mora ... também o juízo sobre a existência do perigo de constituição de uma situação de facto consumado ou da produção de prejuízos de difícil reparação, não tem de ser um juízo de certeza, mas apenas um juízo de probabilidade» - Mário Aroso de Almeida e Fernandes Cadilha, CPTA Anotado, 2a ed. 2007 pág. 712.

56 - Esteve pois muitíssimo bem o Tribunal a quo ao sustentar que «para o decretamento da providência conservatória não se impõe uma indagação exaustiva da existência do direito invocado pelo requerente, mas de qualquer forma tal decretamento não pode ter lugar se não forem recolhidos, em termos de matéria de facto, indícios suficientes da verosimilhança de tal direito, pois, só perante a existência de tais elementos de prova será possível ao julgador formular um juízo positivo a respeito da aparência do direito invocado» - pág. 40 do douto Acórdão recorrido.

57 - A recorrente $C$... insiste na pág. 8 da sua alegação no erro de confundir o requisito do fumus non malus iuris com o do fumus boni iuris ao sustentar que é exigido para o decretamento das providências cautelares conservatórias de suspensão de eficácia «dos três actos administrativos suspendendos» que o tribunal identifique a prova que o levou a considerar que a aprovação desses 3 actos «pode ser ilegal», quando a lei processual administrativa exige apenas que se conclua que não é manifesta a falta de fundamento da pretensão formulada no processo principal ou a existência de circunstâncias que obstem ao seu conhecimento de mérito.

58 - «Para que uma providência conservatória possa ser concedida... não é necessário um juízo de probabilidade quanto ao êxito do processo principal, basta que não seja evidente a improcedência da pretensão de fundo do requerente ou a falta do preenchimento de pressupostos dos quais depende a própria obtenção de uma pronúncia sobre o mérito» Mário Aroso de Almeida e Fernandes Cadilha, CPTA Anotado, 2 ed. 2007 pág. 706.

59 - A recorrente C..., em clara subversão das regras do jogo, procura fazer prova perante o STA de novos factos, através da junção aos autos do doc. 1 anexo à sua alegação, apesar de saber que «a revista só pode ter como fundamento a violação de lei substantiva ou processual» e que «aos factos materiais fixados pelo tribunal recorrido, o tribunal de revista aplica definitivamente o regime jurídico que julgue adequado» - art. $150^{\circ}$ 2. e 3. do CPTA, pelo que não deverá ser levado em consideração o documento anexo à sua alegação. 
60 - Nenhuma razão assiste à recorrente C... quando afirma na pág. 11 da sua alegação que «ao invés da prova e demonstração dos factos integradores dos pressupostos ou requisitos em questão, bastou-se o Tribunal ... com a utilização de expressões vagas e genéricas», acrescentando que «no elenco dos factos provados, mesmo depois de ampliada a matéria de facto, não se encontram factos que sejam hábeis para provar a existência de periculum in mora», uma vez que o douto Acórdão recorrido assentou fundamentalmente nos factos indicados nas pág.s 34 e 45 e nos artigos 40 a 44, 77, 78,80 e 81 do requerimento inicial para os quais remete na pág. 45 .

61 - Ao contrário do sustentado pela recorrente C... na pág. 14 da sua alegação «o requisito do periculum in mora» não foi dado por preenchido apenas porque o tribunal considerou que «existe uma dúvida sobre os riscos aqui em causa», mas sim porque foram dados como provados os factos supra-enunciados que permitiram concluir pela existência do fundado receio da constituição de uma situação de facto consumado e da produção de prejuízos de difícil reparação para os interesses que os recorridos visam assegurar no processo principal e bem assim de que não é manifesta a falta de fundamento da pretensão formulada ou a formular nesse processo ou a existência de circunstâncias que obstem ao seu conhecimento de mérito.

62 - Quanto à questão da «constituição de uma situação de facto consumado», invocada pela recorrente C... nas pág.s 14 a 16 da sua alegação, sem indicar qual a questão em concreto a ser apreciada pelo STA, reitera-se a afirmação de que o recurso excepcional de revista previsto no art. $150^{\circ}$ 1. do CPTA não serve para levar o STA a clarificar este ou aquele conceito jurídico, mas sim a apreciar questão ou questões concretas que, pela sua relevância jurídica ou social, se revista ou revistam de importância fundamental e tenham sido decididas pelo Tribunal recorrido.

63 - O Tribunal a quo não considerou que «eventuais e não provados danos no ambiente provocados pela co-incineração pudessem (na dúvida) constituir uma situação de facto consumado» pág. 18 da alegação da C...), tendo-se baseado sim em factos concretos e provados, que revelam a produção de significativos e irreversíveis danos na saúde pública e no meio ambiente, para concluir pela verificação do fundado receio da constituição de uma situação de facto consumado.

64 - A questão da «dúvida existente sobre os riscos aqui em causa» a que se alude na pág. 45 do douto Acórdão recorrido) reporta-se ao fundado receio da produção de prejuízos de difícil reparação e não ao «periculum in mora na vertente da constituição duma situação de facto consumado» (pág. 45).

65 - 0 juiz na dúvida deve decidir «pro salute ou pro ambiente», como refere Carla Amado Gomes in Cadernos de Justiça Administrativa 63, pág 55.

$\mathrm{O}$ Exm. ${ }^{\circ}$ Procurador Geral Adjunto emitiu o seguinte parecer:

“1. Nos termos dos arts. $146^{\circ}, n^{\circ} 1$ e 9o, $n^{\circ} 2$ do C.P.T.A. o M.P. deve intervir quando estão em causa direitos fundamentais dos cidadãos e de interesses públicos especialmente relevantes, tais como a saúde pública, ambiente, qualidade de vida, urbanismo, ordenamento do território e outros.

A questão dos presentes autos respeita ao ambiente, saúde pública qualidade de vida pelo que, dúvidas não há, que ao M.P., neste caso cumpre emitir parecer.

2. O processo cautelar, como é por demais sabido, destina-se assegurar a utilidade da lide, isto é, de um processo que normalmente mais ou menos longo, porque implica uma cognição plena. No fundo destina-se a assegurar que a sentença que vier a ser proferida no processo principal tenha efeito útil (1-Vieira de Andrade, A Justiça Administrativa, 335 e Carlos Cadilha Dicionário Contencioso Administrativo, 543)

Aliás, o art. $112^{\circ}, n^{\circ} 1$ do CPTA dispõe - "quem possua legitimidade para intentar um processo junto das tribunais administrativos pode solicitar a adopção da providência ou das providências cautelares antecipatórias ou conservatórias, que se mostrem adequadas a assegurar a utilidade da sentença a proferir nesse processo".

Contudo, como se trata de um processo cuja decisão é sempre provisória urgente

exige-se ao Juiz um juízo de prognose devendo o mesmo colocar-se "na situação futura de uma hipotética sentença de provimento, para concluir se há, ou não, razões para recear que tal sentença venha a ser inútil, por entretanto se ter consumado uma situação de facto incompativel com ela, ou por se terem produzido prejuízos de difícil reparação para quem dela deveria beneficiar, que obstem à reintegração específica da sua esfera jurídica (2 - Vieira de Andrade, ob. cit.). A decisão de um processo cautelar é pois, muito delicada já que é tomada necessariamente, com base em informação insuficiente para uma decisão de fundo do processo principal, as mais das vezes sob grande pressão do factor tempo e, por 
isso, não admira que o legislador tenha procurado regular minuciosamente os critérios de tomada da decisão judicial (3 - João Caupers, Introdução ao Direito Administrativo, 9a ed. 407).

Daí que o julgador tenha que ter em muito devida atenção ao disposto principalmente, no art. $120^{\circ}$, $n^{\circ}$ S. 1 e 2 do CPTA.

Nos termos do art ${ }^{\circ} 120^{\circ}, n^{\circ} 1$ - b) do CPTA e sem prejuízo do disposto nos números seguintes, as providências cautelares são adoptadas «Quando, estando em causa a adopção de uma providência conservatória, haja fundado receio da constituição de uma situação de facto consumado ou da produção de prejuizos de difícil reparação para os interesses que o requerente visa assegurar no processo principal e não seja manifesta a falta de fundamento da pretensão formulada ou a formular nesse processo ou a existência de circunstâncias que obstem ao seu conhecimento de mérito».

Por sua vez, dispõe o $n^{\circ} 2$ do mesmo preceito legal, que «Nas situações previstas nas alíneas b) e c) do número anterior, a adopção da providência ou das providências será recusada quando, devidamente ponderados os interesses públicos e privados, em presença, os danos que resultariam da sua concessão se mostrem superiores àqueles que podem resultar da sua recusa, sem que possam ser evitados ou atenuados pela adopção de outras providências».

São, assim, três os requisitos de que depende a concessão de uma providência conservatória (como é o caso da suspensão de eficácia do acto) e cuja verificação é cumulativa:- o fumus boni iuris, na sua formulação negativa (fumus non malus iuris); - o periculum in mora;- a superioridade dos danos resultantes da sua concessão, relativamente aos que podem resultar da sua recusa, sem que possam ser evitados ou atenuados pela adopção de outras providências.

Apreciemos então:

Quanto ao fumus bonus iuris: Resulta dos citados preceitos legais, que a suspensão de eficácia do acto, como providência conservatória, não se basta com o periculum in mora e a ponderação de interesses. O CPTA, diferentemente do que acontecia face à LPTA com a tradicional suspensão de eficácia, exige também o requisito do fumus bonus iuris, embora na sua formulação negativa, ou seja, exige-se agora também aqui a aparência do bom direito, tendo-se, porém, por satisfeito este requisito, com a inexistência de elementos que tomem manifesta a improcedência ou a inviabilidade da pretensão do requerente, o que, tratando-se de factos negativos, transfere para a entidade requerida o ónus de provar a existência desses elementos ( $a r t^{\circ} 344^{\circ}$ do CC), sem prejuizo da sua apreciação oficiosa, necessáriamente perfunctória, dentro do juízo de prognose possível nesta sede.

$E$, assim sendo, uma vez demonstrado o periculum in mora e sem prejuízo da ponderação a que se refere 0 art ${ }^{\circ} 120^{\circ}, n^{\circ} 2$, a providência de suspensão de eficácia será sempre concedida, a menos que «seja manifesta a falta de fundamento da pretensão formulada ou a formular (no processo principal) ou a existência de circunstâncias que obstem ao conhecimento do mérito», o que, pelas razões referidas, não cabe ao requerente demonstrar.

E isto é assim, porque tratando-se de uma providência conservatória, a mesma

destina-se a manter o status quo, pelo que se justifica uma menor exigência quanto à aparência do bom direito do que nas providências antecipatórias previstas na alínea c) do $n^{\circ} 1$ do mesmo preceito $e$ que visam alterar o status quo, daí que nestas últimas, o fumus boni iuris intervém na sua formulação positiva, ou seja, só podem ser concedidas quando seja de admitir «que a pretensão formulada ou a formular (no processo principal) pode vir a ser julgada procedente» (4-Ac. de 14.7.08, $n^{\circ} 0381 / 08$ do STA).

3. Exige-se, pois, ao Juiz que através dos elementos de facto que lhe são apresentados e também através daqueles que entenda necessário ainda recolher possa decidir sumária e rapidamente (este tipo de processo é urgente) sobre o deferimento ou não da providência cautelar verificados que estejam ou não aqueles requisitos. Não se exige uma prova total para a decisão como é e deve ser exigida para a decisão da acção principal que como é óbvio, exige uma avaliação e uma indagação muito mais cuidadas. Assim, no caso concreto, é de aceitar que o tribunal não tenha inquirido as testemunhas apresentadas pelas partes já que do processo, no seu entendimento, constavam elementos suficientes para decidir. O Juiz decisor não se encontra vinculado às provas que tenham sido carreadas pelas partes. Nos termos do disposto no art. $265^{\circ}, n^{\circ} 3$ do C.P.C. subsidiariamente aplicável ao contencioso administrativo por força do disposto no art. $42^{\circ}, n^{\circ} 1$ do CPTA" incumbe ao juiz realizar ou ordenar, mesmo oficiosamente, todas as diligências necessárias ao apuramento da verdade e à justa composição do litígio, quanto aos factos que lhe é lícito conhecer". E, no fundo, a enunciação do princípio do inquisitório (5 - Como escreve Carla Amado Gomes, in CJA, a co-incineração nas malhas da precaução, "no âmbito dos processos intentados por autores investidos em legitimidade popular, em virtude da 
natureza dos bens em jogo cabe ao juiz a iniciativa própria em matéria de provas, sem vinculação à iniciativa das partes, art. $17^{\circ}$ da Lei $n^{\circ} 83 / 95$ de 31/8.). E também o art. $118^{\circ}, n^{\circ} 3$ do CPTA dispõe que o juiz" pode ordenar as diligências de prova que considere necessárias. Com as limitações impostas pelo art. $264^{\circ}$ do CPC o juiz tem uma grande amplitude na recolha da prova dos factos e, certo é, que não se verificam os pressupostos dos arts. $729^{\circ}$ e $730^{\circ}$ do C.P.C para que este STA amplie a matéria de facto cada como provada.

4. O Ac. recorrido do TCAN deu por adquirido que a suspensão da eficácia não pode ser concedida à luz do requisito constante da alínea a) do art. $120^{\circ}, n^{\circ} 1$ do (PTA. E concluiu que se verificava o requisito constante na alínea b) do mesmo número e artigo, ou seja, que se verificava o requisito do periculum in mora na vertente da constituição duma situação de facto consumado por haver fundado receio de que se a providência for recusada se tornará impossivel a reintegração no plano dos factos da situação conforme à legalidade uma vez decidido o processo principal com decisão favorável à pretensão do requerente cautelar.

Depois, fazendo a análise dos interesses em jogo (no cumprimento do imposto pelo

$n^{\circ} 2$ do art. $120^{\circ}$ referido) concluiu que os danos causados com a recusa da providência são superiores aos danos causados com a sua concessão e que o princípio da precaução (a considerar no âmbito do direito do ambiente) aconselha, mesmo em caso de dúvida, que seja concedida a providência salvaguardando em primeiro lugar a saúde e o bom ambiente (6-vide fls. 1045/53 do Ac. Recorrido).

4.1. Porém, não resulta da matéria de facto dada como assente (7 - Vide fls. 1028/30 e 1041 do Ac recorrido) que se possa considerar verificado o requisito do periculum in mora na vertente de constituição de uma situação de facto consumado, tal como ali foi entendido. Como tribunal de revista este STA limita-se a aplicar o direito aos factos materiais fixados pelo tribunal recorrido, acatando, em princípio, a matéria de facto fixada de acordo com o disposto no art. $150^{\circ} \mathrm{n}^{\circ} \mathrm{S} .3$ e 4 do CPTA e no art. $729^{\circ}$ do CPC.

4. 2. Por outro lado, a verificação do requisito positivo periculum in mora para o decretamento de uma providência cautelar pressupõe a existência de "fundado receio" da ocorrência de determinadas circunstâncias geradoras de uma situação de facto consumado ou de prejuízos de difícil reparação para os interesses que o requerente visa assegurar no processo principal. A análise dos factos concretos deverá permitir "concluir que a situação de risco é efectiva e não uma mera conjectura, de verificação apenas eventual "(8-Comentário ao CPTA, Aroso de Almeida/Cadilhe, Almedina, 2005, 606).

Ora, através do providência cautelar requerida, os requerentes propõem-se defender o direito ao ambiente e o direito à saúde das populações residentes nas povoações de Souselas e limítrofes que eventualmente poderão ser postos em causa com a co-incineração dos resíduos considerados perigosos. Mas, jamais da prova produzida e assente se pode concluir que a queima de tais resíduos na fábrica de cimento de Souselas provoque uma situação de efectivo risco e da produção provável dos danos invocados em fundamento do pedido de providência cautelar. Dos factos dados como provados não resulta evidente nem fundadamente provável que a co-incineração de resíduos industriais perigosos acarrete, actualmente, prejuízos para o ambiente e para a saúde das populações.

Como assim, fica desde logo afastado o fundado receio de produção de uma situação de facto consumado, lesiva dos interesses que os requerentes visam assegurar na acção principal. E é sabido que o requisito periculum in mora se mostra preenchido "sempre que os factos concretos alegados pelo requerente permitam perspectivar a criação de uma situação de impossibilidade de restauração natural da sua esfera jurídica, no caso de o processo principal vier a ser julgado procedente "(9-Parecer do M.P. no proc. 0471/o7 deste STA). Logo, perante a ausência de prova indubitável (que incumbia aos requerentes nos termos do art. $114^{\circ}-g$ ) do (PTA) de que no caso concreto há prejuízo para o ambiente e para a saúde das populações com a co-incineração, jamais se poderá configurar a existência do periculum in mora e, assim, a providência cautelar terá que ser indeferida Acresce que, como se escreveu no douto Ac. de 31.10.2007, rec. $n^{\circ}$ 0471/o7 deste STA e num caso concreto quase igual ao deste processo - "Numa acepção lata, todo o facto acontecido se consuma "qua tale», dada a irreversibilidade do tempo; mas não é obviamente esse o sentido da expressão da lei. Na economia do preceito, o "facto» será havido como «consumado» por referência ao fim a que se inclina a lide principal, de que o meio cautelar depende; e isto significa que só ocorre uma «situação de facto consumado» quando, a não se deferir a providência o estado de coisas que a acção quer influenciar ganhará entretanto a irreversível estabilidade inerente ao que já está terminado ou acabado - ficando tal acção inutilizada «ex ante». Ora, mesmo que encarássemos a acção principal como tendente a eliminar de vez práticas de co-incineração entretanto licenciadas, teríamos de lhe reconhecer a utilidade de suprimir essas 
práticas para o futuro - e isso, por si só excluiria qualquer ideia de um anterior «facto consumado». Afastada a tal «situação de facto consumado», claudica imediatamente tudo o mais, que em torno disso gravitava - designadamente o trecho do aresto que dessa «situação» infere o "periculum in mora»".

E assim sendo, diremos nós, não faz qualquer sentido chamar à colacção o denominado princípio da precaução em matéria ambiental já que não há qualquer dúvida quanto à situação de facto consumado e é por demais duvidoso que tal princípio seja aqui de aplicar enquanto princípio jurídico (10 - Sobre o Princípio da Precaução em matéria ambiental - Carla Amado Gomes, ob. Cit. 56/9).

5. Sendo certo, que também não existe matéria de facto suficientemente provada que permita a conclusão na ponderação de interesses a que chegou a decisão sob recurso. Bem pelo contrário, da prova produzida parece até resultar que os danos com a suspensão da eficácia das licenças são muito superiores aos danos que resultariam da recusa de tal suspensão. Basta ler a fundamentação da RESOLUÇÃO FUNDAMENTADA do MAOTDR a fls. 297/8. De qualquer modo, não se consubstanciando o requisito do periculum in mora da alínea b) do art. $120^{\circ}, n^{\circ} 1$ do CPTA como ficou demonstrado acima, tal questão nem se deve colocar.

6. Por tudo o expendido e no seguimento diz jurisprudência que vem sendo fixada por este STA no que respeita a estas questões de co-incineração (Acs. de 10.1.07 e de 31.10.07, respectivamente, recursos $n^{\circ}$ S 0675/o 7 e 0471/07) somos de parecer que o presente recurso de revista merece provimento."

Os recorridos, notificados de tal parecer, responderam suscitando a questão da ilegitimidade do Ministério Público para intervir no processo e reiterando as posições assumidas nas contra alegações no sentido da improcedência do recurso (1302/1312).

II. A decisão recorrida considerou assentes, e com relevância para os autos, os seguintes factos fixados em 1 a instância:

A - Foi aprovada a Lei $n^{\circ} 20 / 99$, de 15 de Abril que impôs a criação pelo Governo de um Plano Estratégico Nacional de Gestão de Resíduos, por via de Decreto-Lei, tendo determinado a suspensão do Decreto-Lei n은 $273 / 98$, de 2 de Setembro no que respeitava às operações de co-incineração de resíduos industriais perigosos e determinado a constituição de uma Comissão Científica Independente, por via de Decreto-Lei, o que veio a suceder através do DL n $120 / 99$, de 16 de Abril, que institui a Comissão Científica Independente (CCI) de controlo da co-incineração, tendo a CCl elaborado, em Maio de 2000 , o parecer que constitui documento $\mathrm{n}^{\circ} 2$, junto pela entidade requerida e onde se refere no ponto 9.4 Conclusão "Em conclusão, para efeito do disposto no $n .{ }^{\circ} 4$ do artigo $5^{\circ}$ da Lei n‥ 22/200o, de 10 de Agosto, e uma vez asseguradas as condições anteriormente enunciadas, entende-se, tendo em atenção o estado actual dos conhecimentos e os resultados de estudos realizados noutros países em situações similares, dar parecer positivo ao desenvolvimento das operações de co-incineração de resíduos industriais". Houve um voto de vencido onde se refere “...Apesar da controvérsia, há suspeitas de perigosidade no tocante à co-incineração... Face às dúvidas de natureza científica, informo que não subscrevo o relatório do grupo médico";

B - Foi ainda aprovada a Lei $n^{\circ} 22 / 2000$, de 10 de Agosto, onde se estabeleceu que «o impacto sobre a saúde pública dos processos de queima de resíduos industriais perigosos (RIP), tendo em conta a sua localização, junto de zonas habitadas, será objecto de relatório específico, a elaborar pela Comissão Cientifica Independente», na sequência da qual foi criado o Grupo de Trabalho Médico que, por relatório datado de 11 de Dezembro de 2000, entendeu «dar parecer positivo ao desenvolvimento das operações de co-incineração de resíduos industriais» - cfr. doc. $n^{\circ} 1$ anexo à oposição e que aqui se dá como inteiramente reproduzido;

C - Na sequência da decisão do Governo de fazer cessar a suspensão do Decreto-Lei n $273 / 98$, de 2 Setembro, no que respeita às operações de co-incineração de resíduos industriais perigosos, através do Decreto-Lei $n^{\circ}$ 154-A/2001, de 8 de Maio, e na senda das recomendações da CCl, foram realizados no Centro de Produção de Souselas os testes referidos no documento junto pela contra-interessada, concluindo-se, em Outubro de 2001, nos termos aí expressos, que os testes realizados permitem «confirmar a adequação da co-incineração em unidades cimenteiras para o tratamento de resíduos industriais perigosos» e que a co-incineração não implica “emissões acrescidas de dioxinas/furanos»;

D - Em 2001 foi realizado Miniteste de Co-incineração em Souselas cujos resultados constam do relatório de fls. 521-533 e que aqui se dá como inteiramente reproduzido (- O relatório apresenta o seguinte comentário final e conclusões (fls. 532): "O miniteste da queima de Resíduos Industriais Perigosos levado a cabo no forno 2 da cimenteira de Souselas, de 16 a 27 de Julho de 2001, permitiu confirmar 
a adequação da opção da co-incineração em unidades cimenteiras para o tratamento de resíduos industriais perigosos cujo destino final requer a destruição térmica. Mais permitiu adquirir experiência e conhecimentos que facilitarão grandemente a realização dos testes definitivos no futuro próximo.

No que concerne à destruição térmica dos resíduos verifica-se que o processo de co-incineração em cimenteiras satisfaz os requisitos críticos para a destruição térmica de RIP. Os níveis de emissão de efluentes são os normais para uma cimenteira a funcionar com combustível clássico e bastantes baixos para dioxinas e metais. Com Combustível Alternativo (CA), e independentemente das quantidades de CA admitidas ao forno, não há acréscimo das emissões de dioxinas/furanos. As emissões de dioxinas/furanos são inferiores ao limite de detecção de 10 pg 1-TEQ/m3, que é dez vezes inferior ao limite máximo permitido de $100 \mathrm{pg}$ 1-TEQ/m3. Conforme repetidamente a CCl havia afirmado nos seus relatórios e em declarações públicas, não há emissões acrescidas de dioxinas/furanos pela combustão de RIP até ao máximo permitido para a percentagem de substituição do combustível normal.

0 mesmo se verifica para os metais pesados, cujas concentrações são indistinguíveis, dentro da variabilidade natural do processo de produção de cimento, entre o processo de co-incineração e o funcionamento com combustível normal.

O sistema de associação de filtros electrostáticos e de mangas revela-se muito eficiente, para além de evitar descargas periódicas de enormes quantidades de partículas quando, devido a instabilidade dos fornos, era necessário desligar os filtros electrostáticos. Para o processo de co-incineração os valores medidos são em média 20 vezes mais baixos do que os impostos pela legislação nacional e 8 vezes inferiores aos indicados pela Directiva Europeia.

As restantes emissões de efluentes encontram-se igualmente dentro dos limites fixados pela legislação vigente.

...")

E - Com data de 15 de Novembro de 2006 foi emitida Licença ambiental ao operador C... (fls. 28-73);

F - Com data de 24-11-2006 foi notificada a C... da Licença de instalação referente à co-incineração de resíduos perigoso e não perigosos (fls. 74-84);

G - Com data de 24 de Janeiro de 2008 foi emitida a Licença de Exploração n. ${ }^{\circ}$ 2/2008/DOGR (fls. 87-96);

$\mathrm{H}$ - Em Dezembro de 2005 foi elaborado Relatório de actualização dos processos de Co-incineração de resíduos em articulação com os CIRVER (doc. n. ${ }^{\circ} 4$ anexo à oposição da entidade requerida MA e que aqui se dá como inteiramente reproduzido);

I- Nos termos do Decreto-Lei $78 / 2004$ foi realizado o autocontrole das emissões atmosféricas do Centro de Produção de Souselas (Doc. N. ${ }^{\circ} 3$ anexo à oposição da entidade requerida e que aqui se dá como inteiramente reproduzido);

O acórdão recorrido considerou, ainda, como assentes os seguintes factos:

J- Dá-se aqui por rep. o parecer da Quercus «Análise dos Resultados dos Testes de Co-Incineração realizados em Souselas de Julho de 2001» (doc. 1 anexo)

L) Dá-se aqui por rep. o parecer dos médicos ... e ....

M) Dá-se aqui por rep. o Relatório do Prof. Doutor ....

N) Dá-se aqui por reproduzida a Resolução Fundamentada proferida pelo Ministro do Ambiente em $12 / 6 / 08$ e junta aos autos de fls 278 a 287.

III - O Tribunal Central Administrativo Norte, revogando a sentença do Tribunal Administrativo e Fiscal de Coimbra, deferiu o pedido de suspensão de eficácia dos actos de licenciamento identificados pelos recorridos no seu requerimento inicial, a saber:

actos de concessão da:

a) licença ambiental, emitida em 15.11.2006, à fabrica da C... de Souselas, denominada «Centro de Produção de Souselas» para a co-incineração de resíduos;

b) licença de instalação, emitida em 24.11.2006, à fabrica da C... de Souselas, denominada «Centro de Produção de Souselas» para a co-incineração de resíduos perigosos e não perigosos;

e) licença de exploração nr. 2/2008/DOGR, emitida em 24.01.2008, à fábrica da C... de Souselas, denominada «Centro de Produção de Souselas» para a co-incineração de resíduos perigosos.

O TAF, considerando que não foi feita qualquer prova sobre os concretos prejuízos decorrente da queima de resíduos perigosos na cimenteira de Souselas resultava uma emissão tóxica de dioxinas ou furanos superiores ao legalmente permitido, julgou não verificado o requisito do periculum in mora e, em consequência, indeferira os pedidos de suspensão de eficácia formulados pelos requerentes. 
IV. O Ministério do Ambiente, do Ordenamento do Território e do Desenvolvimento Regional imputa ao acórdão recorrido nulidade por omissão de pronúncia sobre a questão da violação do princípio do contraditório relativamente ao pedido de intimação

A nulidade de sentença por omissão de pronúncia verifica-se quando o Tribunal deixe de se pronunciar sobre questões sobre as quais deveria ter-se pronunciado - art. $668^{\circ}, \mathrm{n} .{ }^{\circ} 1$, alínea d), do CPC, aplicável por força do disposto no art. 1. ํㅡㄹ do CPTA].

Esta nulidade está relacionada com os deveres de cognição do Tribunal, previstos no art. 660. , n. ${ }^{\circ}$ 2, do CPC, em que se estabelece que o juiz tem o dever de conhecer de todas as questões que as partes tenham submetido à sua apreciação, exceptuadas aquelas cuja decisão esteja prejudicada pela solução dada a outras.

No caso em apreço, o Tribunal Central Administrativo Norte referiu-se a essa questão na parte final da sua página 52 (fls. 1059 do processo), a propósito do pedido de intimação, dizendo o seguinte:

O conhecimento deste pedido fica prejudicado já que o conteúdo do mesmo está absorvido pelas consequências do provimento do pedido cautelar. Pelo que, carece de relevância aferir se estamos ou não perante um lapso evidente por o pedido carecer de sentido se não fosse entendendo-se que se reportava à fábrica da C... de Sousela; da cumulação de um processo de intimação como este, previsto no art. $109^{\circ}$ do CPTA, que é um processo principal com um processo cautelar e ainda se foi ou não cumprido o princípio do contraditório.

É evidente, assim, por ser dito de forma expressa, que o Tribunal Central Administrativo Norte entendeu estar prejudicada a questão de saber se havia sido violado o princípio do contraditório.

Como tem vindo a ser jurisprudência uniforme deste Supremo Tribunal Administrativo se o Tribunal não conhece de uma questão suscitada pelas partes por entender que está prejudicado o seu conhecimento, poderá estar-se perante um erro de julgamento, se tal entendimento for errado, mas não se está perante uma nulidade por omissão de pronúncia.

Isto é, a nulidade por omissão de pronúncia só ocorre em casos em que o Tribunal não toma posição sobre qualquer questão colocada à sua apreciação, inclusivamente no decidindo explicitamente que no pode dela tomar conhecimento.(Neste sentido, entre muitos outros, podem ver-se os acórdãos deste Supremo Tribunal Administrativo de 18-2-1998, recurso n. ${ }^{\circ}$ 21665, publicado em Apêndice ao Diário da República de -DR de 8-11-2001, página 496; de 13-5-98, recurso n. ${ }^{\circ}$ 21901, publicado em Apêndice ao Diário da República de 30-11-2001, página 1701; e de 18-12-2002, recurso n. ${ }^{\circ} 1634 / 02$, publicado em Apêndice ao Diário da República de 12-3-2004, página 2979.

No mesmo sentido, pronuncia-se ALBERTO DOS REIS, em Código de Processo Civil Anotado, volume V, página 143, dizendo: «uma coisa é o tribunal deixar de pronunciar-se sobre questão que devia apreciar, outra invocar razão, boa ou má, procedente ou improcedente, para justificar a sua abstenção».)

Por isso, no caso dos autos, não ocorre a nulidade invocada pelo MAOTDR.

V. QUESTÃO DA ILEGITIMIDADE DO MPo - fls. 1302

É suscitada a questão da legitimidade do Ministério Público para intervir no presente processo.

0 art. $9 .^{\circ}$, n. $^{\circ}$ 2, do CPTA atribui ao Ministério Público legitimidade para e o Ministério Público «intervir, nos termos previstos na lei, em processos principais e cautelares destinados à defesa de valores e bens constitucionalmente protegidos, como a saúde pública, o ambiente...».

0 art. $146 .^{\circ},{ }^{\circ}{ }^{1}$, do mesmo Código permite ao Ministério Público, quando não se encontre na posição de recorrente ou recorrido, pronunciar-se sobre o mérito do recurso, em defesa dos direitos fundamentais dos cidadãos, de interesses públicos especialmente relevantes ou de algum dos valores ou bens referidos no.$^{\circ} 2$ do artigo $9 .^{\circ}$.

Destas normas decorre que o Ministério Público tem legitimidade global para intervir em processos em que estejam em causa valores ambientais, como é manifestamente o caso do presente processo.

Por outro lado, no presente recurso excepcional de revista, como está já decidido no acórdão de 7-52009, que admitiu o recurso e transitou em julgado, está em causa matéria que «interessa a todos os cidadãos pela necessidade geral de dar destino» a resíduos industriais perigosos, matéria essa que foi qualificada como de «relevância social especialmente qualificada» pelo que é de concluir que está-se também perante «interesses públicos especialmente relevantes» para efeitos do citado art. $146 .^{\circ}, \mathrm{n} .^{\circ} 1$, do CPTA.

$\mathrm{E}$, quando tem legitimidade para intervir processualmente, o Ministério Público pode fazê-lo ou não, e, quando o faz, pode fazê-lo conforme entender, como é corolário do seu estatuto de autonomia, constitucionalmente reconhecido (art. $219 .^{\circ}, \mathrm{n} .^{\circ} 2$, da CRP). 
Nestes termos, improcede a questão prévia suscitada pelos requerentes a fls. 1302.

\section{QUESTÃO DO PRINCÍPIO DA PRECAUÇÃO}

O acórdão recorrido escreve:

“Ora, no caso sub judice, resulta do mini-teste de queima de RIP realizado no teste 2 da cimenteira de Souselas de 16 a 27/7/01 junto aos autos e à matéria de facto, que "não há emissões acrescidas de dioxinas/furanos pela combustão de RIP até ao máximo permitido para a percentagem de substituição de combustivel normal ..."

Por outro lado são feitos uma série de alertas quanto a testes futuros que deverão ser em melhores condições.

Este mini-teste é feito pela CCI na sequência do parecer de Maio de 2000 que conclui que a "emissão de dioxinas/furanos devida à queima de RIP em co-incineração por cimenteiras em Portugal não tem relevância ambiental a nivel local regional ou global".

Contudo, o parecer do grupo de trabalho médico junto de fls 460 a 470 dos autos conclui que: "A evidência científica disponível quanto à co-incineração aponta no sentido de que a substituição de uma parte combustível convencional por resíduos não se traduzirá num acréscimo de emissões nocivas Nestas condições a co-incineração não contribuirá para uma exposição acrescida de substâncias prejudiciais à saúde nem através de emissões para a atmosfera nem através do cimento produzido.

No entanto dever-se-á acautelar a eventualidade de riscos acrescidos a nível das localizações nas quais o processo de tratamento de resíduos em co-incineração possa vir a ocorrer através da prévia caracterização detalhada das condições ambientais de cada local em causa e das posteriores monotorização ambiental e vigilância epidemiológica. Devem por isso esses procedimentos ser assegurados em conjugação com os propostos no relatório diz CC tendentes a garantir a segurança das populações

Em conclusão, para efeito do disposto no $\mathrm{n}^{\circ}{ }_{4}$ do artigo $5^{\circ}$ da Lei 22/2000 de 10 de Agosto, e uma vez asseguradas as condições anteriormente enunciadas..." ( A frase continua com o seguinte teor: “ ... entende-se, tendo em atenção o estado actual dos conhecimentos e os resultados de estudos realizados noutros países em situações similares, dar parecer positivo ao desenvolvimento das operações de co-incineração de resíduos industriais" - cfr. ponto A. da matéria de facto.).

Um dos médicos deste grupo, o Dr. ..., em voto de vencido diz:

"No caso de não haver tratamento ou destino alternativo para alguns resíduos a eliminação dos mesmos deverá ocorrer em condições apropriadas quer sob o ponto de vista técnico (incineradora dedicada) e geográfica, de modo a não causar riscos acrescidos para as comunidades envolventes

Apesar da controvérsia, há suspeitas de perigosidade no tocante a co-incineração. As conclusões estão elaboradas de forma a permitir a aceitação da co-incineração de resíduos industriais perigosos

Face às dúvidas de natureza científica informo que não subscrevo o relatório do grupo médico".

Por outro lado os recorrentes vêm invocar neste processo cautelar as condições geográficas específicas de Souselas, já que a cimenteira está em cima da população de Souselas e a 4,5 Km de Coimbra.

Para tanto invocam nos artigos 40 a 44 da petição, entre outros, factos no sentido da existência de um risco de concentração de poluentes susceptíveis e aumentar o risco de contrair certas doenças por parte de quem vive nas proximidades de uma cimenteira em co-incineração de resíduos industriais perigosos, nomeadamente face à situação crítica, desde logo, da cidade de Coimbra.

Como supra referimos, a necessidade de concretização da situação geográfica concreta já vem alertada no referido relatório médico junto à matéria de facto.

Por outro lado, no art. $112^{\circ}$ da petição vem invocado que a fábrica da C... não está dotada de mecanismos de monotorização capazes de aferir da qualidade do ar envolvente da região e ainda que nada foi feito sobre a prévia caracterização detalhada das condições ambientais apontadas pelo Grupo de Trabalho Médico (arts 77, 78, 80 e 81 da petição).

Ora, não obstante se possa e deva entender que está em causa matéria de cariz essencialmente técnico e por isso sujeita a prova pericial, entendemos que a dúvida existente sobre os riscos aqui em causa tal como foram definidos na causa de pedir justifica que se valorize esta dúvida de forma a julgar verificado o requisito do periculum in mora, por estarem em causa prejuízos plausíveis de difícil reparação.

Assim, a mera prolação do despacho ora posto em crise tem a virtualidade de ser susceptível de implicar a produção de danos para o ambiente ou para a saúde pública, no caso concreto das localidades aqui em causa.

Para além de que a imediata execução dos acto suspendendos com a extensão de todos os efeitos 
potenciais e legais decorrentes da não suspensão da pretensão cautelar é susceptível de gerar uma situação de periculum in mora na vertente da constituição duma situação de facto consumado.

Na verdade, e quanto à situação de facto consumado, cotejando todo o regime legal decorrente dos diplomas em referência nos autos, em particular da conjugação do regime decorrente do DL n. ${ }^{\circ}$ 85/05, de 28/04, do DL n. ${ }^{\circ}$ 69/2000 e suas sucessivas alterações nomeadamente a do DL n. ${ }^{\circ}$ 197/05, de 08/11, do DL n. ${ }^{\circ}$ 194/00, de 21/08 (com alterações igualmente) o não deferimento da pretensão cautelar permitirá que, prosseguindo a exploração da unidade industrial em crise com os inerentes actos materiais de co-incineração, caso se vier a obter procedência na acção principal na qual se discutirá a legalidade do acto suspendendo, a reintegração daquela decisão não se conseguirá obter na sua integralidade, frustrando-se a tutela jurisdicional principal e sua utilidade que se visava obter com a dedução da presente providência cautelar.

É certo que a procedência da aludida acção principal irá implicar, face à sua execução integral, a nulidade dos actos consequentes, eliminando-se o acto de licenciamento de exploração, mas o que não se conseguirá reconstituir e se torna impossível evitar, frustrando-se, desta forma, o efeito útil da tutela a obter a título principal e da satisfação dos eventuais interesses e direitos que estejam na base quer daquela pretensão, são os actos materiais de co-incineração que não poderão ser eliminados por efeito da prolação da sentença na acção principal e em execução/reconstituição da situação fácticojurídica, sem a emissão do acto ilegal.

A plena execução e eficácia dos actos suspendendos irá permitir assim a constituição duma nova realidade material que tomará impossível a reintegração no plano dos factos da situação preexistente à emissão do despacho aqui em causa, obtida a procedência da pretensão formulada pelo aqui recorrido na acção principal.

Existe, pois, um risco fundado de constituição de uma situação de facto consumado por haver fundado receio de que se a providência for recusada se tornará impossível a reintegração no plano dos factos da situação conforme à legalidade uma vez decidido o processo principal com decisão favorável à pretensão do requerente cautelar.

Nessa medida, terá de ter-se como preenchido, com esta fundamentação, o requisito do periculum in mora na vertente da constituição duma situação de facto consumado, não se acompanhando nesse ponto o juízo efectuado na decisão judicial em apreciação que, desta forma, não pode manter-se."

Da alegação dos aqui recorrentes resulta como questão central por ambos colocada o facto do TCA no acórdão recorrido, ao socorrer-se do designado princípio da precaução afastando por essa via o ónus de alegação e prova dos requerentes da providência dos factos integradores do periculum in mora, ter feito incorrecta interpretação e aplicação dos $\operatorname{art}^{\circ} \mathrm{S} 174$, do Tratado CE, do art. ${ }^{\circ} 62, \mathrm{n} .{ }^{\circ} 2$, al. a), da CRP, do art. ${ }^{\circ}$ 3, al. a), da Lei de Bases do Ambiente, e do art. ${ }^{\circ} 120$, n. ${ }^{\circ}$ 1, al. b), 114, n. ${ }^{\circ}$ 3, al. g), e $118, n .^{\circ}$ s 2 e 4 , todos Código de Processo dos Tribunais Administrativos.

Vejamos.

Na Declaração de princípios saída da Conferência das Nações Unidas sobre Meio Ambiente e Desenvolvimento, realizada no Rio de Janeiro de 1992, foi adoptado o denominado princípio da precaução, assim redigido no item 15 do texto:

“De modo a proteger o meio ambiente, o princípio da precaução deve ser amplamente observado pelos Estados, de acordo com suas capacidades. Quando houver ameaça de danos sérios ou irreversíveis, a ausência de absoluta certeza científica não deve ser utilizada como razão sara postergar medidas eficazes e economicamente viáveis para prevenir a degradação ambiental".

Aceitando a ideia de precaução como princípio jurídico, o que não é pacífico na doutrina - o qual não tem consagração na nossa Lei Constitucional nem no Tratado da União Europeia - a sua aplicação aos procedimentos cautelares não pode ter a extensão que o acórdão recorrido lhe dá. Tal entendimento levaria, como sustentam os recorrentes, a que bastaria uma mera alegação genérica de que a ciência não garante que não há qualquer efeito danoso para o ambiente ou saúde, existindo, assim, sempre um risco potencial, para que qualquer decisão administrativa fosse paralisada, implicando, assim, que, perante a dúvida sobre a causa de um dano ou sobre a sua possível ocorrência, o julgador devia decidir sempre contra o autor do acto administrativo alegadamente causador de tal hipotético e eventual dano.

Como escreve Carla Amado Gomes, por sinal, na anotação referida no acórdão recorrido (Cadernos de Justiça Administrativa, n. ${ }^{\circ} 63$, pág. 55 a 59), traduzir-se-ia na introdução de um critério material na ponderação dos interesses em jogo que "desequilibra totalmente o balancing process previsto no n. ${ }^{\circ}$ 2, do art. 120, do CPTA". 
Não tendo, tal princípio, consagração expressa na Lei portuguesa, designadamente na CRP - que, no artigo 66, n. ${ }^{\circ}$ 2, prescreve que, genericamente, incumbe ao Estado "prevenir e controlar a poluição e os seus efeitos e as formas prejudiciais de erosão" -, nem no Tratado da União Europeia, - que no seu art. $174 .^{\circ}$ define princípios gerais de preservação e protecção ambiental - não há suporte legal para o afirmar como princípio jurídico vigente na nossa ordem jurídica, devendo antes ser entendido como mera orientação política dos Estados, que o devem ter em conta nas suas opções políticas e legislativas. Daí que aquele invocado princípio não tenha a potencialidade, nem de se sobrepor ao critério jurídico do CPTA no que respeita à verificação dos requisitos do deferimento das providências cautelares, maxime do art. $^{\circ} 120, \mathrm{n}^{\circ}{ }^{\circ}$, al. b), nem de inverter a regra do ónus da prova consignada no art. $342 .^{\circ}$ do Código Civil.

Â face do nosso ordenamento jurídico, o princípio da precaução não foi adoptado como critério de decisão da prova, não podendo com base na mera falta de certeza da não produção de danos ambientais ou para a saúde pública o julgador concluir pela existência de receio de produção de danos ambientais e para a saúde pública, de difícil reparação ou irreversíveis, quando não se demonstra positivamente, mesmo de forma sumária, a existência de uma probabilidade séria de eles virem a ocorrer.

Trata-se de uma opção legislativa discutível, em termos de política legislativa, mas que se justificará pela ponderação da necessidade de prossecução de outros interesses públicos, que se entendeu não dever ser obstaculizada por meros receios de danos eventuais ou hipotéticos, que não se demonstra com grau de probabilidade séria que possam vir a ocorrer.

Assim sendo, o acórdão recorrido ao resolver a dúvida que diz existir sobre os riscos para a saúde pública e ambiente da queima de resíduos perigosos em Souselas no sentido da sua efectiva verificação viola aquela regra do ónus da prova.

\section{PERICULUM IN MORA DERIVADO DE PREJUÍZOS DE DIFÍCIL REPARAÇÃO}

$O$ acórdão recorrido, ponderando a prova produzida, chegou a uma situação em que entendeu subsistirem dúvidas sobre a existência de riscos para a saúde e para o ambiente derivados dos actos suspendendos.

A ponderação da prova produzida e o juízo sobre a subsistência de dúvidas inserem-se no julgamento da matéria de facto, pelo que está fora dos poderes de cognição deste Supremo Tribunal Administrativo, em recurso de revista, apreciar tal juízo, uma vez que não se está perante qualquer das situações indicadas no art. $1500^{\circ}, \mathrm{n}^{\circ} \mathrm{S} 3$ e 4 , do CPTA.

O Tribunal Central Administrativo Norte valorizou essas dúvidas «de forma a julgar verificado o requisito do periculum in mora, por estarem em causa prejuízos plausíveis de difícil reparação» (fls. 1052).

Ao efectuar esta valorização das suas dúvidas, o acórdão recorrido fez aplicação do entendimento que atrás referira sobre a inversão do ónus da prova, resultante da aplicação do princípio da precaução, decidindo que esse ónus recai sobre os Requeridos. Não sendo de adoptar este entendimento sobre a inversão do ónus da prova, como acima se viu, é aplicável a regra do art. $^{\circ} 342 .^{\circ}$, n. $^{\circ} 1$, do Código Civil, que estabelece que «àquele que invocar um direito cabe fazer a prova dos factos constitutivos do direito alegado», pelo que a situação de dúvida quanto aos danos para a saúde e para o ambiente tem de ser valorizada contra os requerentes ( $\operatorname{art}^{\circ} 516$, do CPCivil), considerando não haver receio fundamentado de que esses danos venham a ocorrer.

Por isso, é de concluir que não se verifica prejuízo de difícil reparação, referido no art. $120 .^{\circ}, \mathrm{n} .^{\circ} 2$, alínea b), do CPTA como requisito da adopção de providências cautelares conservatórias.

\section{PERICULUM IN MORA DERIVADO DE CRIAÇÃO DE UMA SITUAÇÃO DE FACTO CONSUMADO}

Como resulta do texto da alínea b) do $n .{ }^{\circ} 2$ do art. $120 .^{\circ}$ do CPTA, o requisito do periculum in mora pode ser preenchido pela existência de fundado receio da constituição de uma situação de facto consumado.

No acórdão recorrido, concluiu-se também que se verifica o requisito do periculum in mora na vertente da constituição de uma situação de facto consumado, «por haver fundado receio de que se a providência for recusada se tornará impossível a reintegração no plano dos factos da situação conforme à legalidade uma vez decidido o processo principal com decisão favorável à pretensão do requerente cautelar». (fls. 1053).

Quanto a esta vertente do periculum in mora, não se refere explicitamente no acórdão recorrido que o Tribunal ficou perante uma situação de dúvida, nem se faz apelo explícito ao princípio da precaução 
ou outra regra de que resulte a inversão do ónus da prova, pelo que não pode imputar-se ao acórdão recorrido erro idêntico ao cometido a propósito do receio de verificação de prejuízos de difícil reparação.

Há, no entanto, erro de direito na interpretação do conceito de «facto consumado», como defende o Recorrente Ministério do Ambiente, do Ordenamento do Território e do Desenvolvimento Regional, nas suas alegações, citando o acórdão deste Supremo Tribunal Administrativo de 31-10-2007, proferido no recurso n. ${ }^{\circ}$ 471/07. Como se refere neste aresto "Numa acepção lata, todo o facto acontecido consuma-se «qua tale», dada a irreversibilidade do tempo; mas não é obviamente esse o sentido da expressão da lei. Na economia do preceito, o "facto» será havido como «consumado» por referência ao fim a que se inclina a lide principal, de que o meio cautelar depende; e isto significa que só ocorre uma «situação de facto consumado» quando, a não se deferir a providência, o estado de coisas que a acção quer influenciar ganhará entretanto a irreversível estabilidade inerente ao que já está terminado ou acabado - ficando tal acção inutilizada «ex ante». Ora, mesmo que encarássemos a acção principal como tendente a eliminar de vez práticas de co-incineração entretanto licenciadas, teríamos de lhe reconhecer a utilidade de suprimir essas práticas para o futuro - e isso, por si só, excluiria qualquer ideia de um anterior "facto consumado». Estas considerações são transponíveis para o caso dos autos pelo que, na linha desta jurisprudência, que se adopta, não tendo ficado demonstrado que a não adopção da providência torne inútil a sentença a proferir no processo principal, designadamente quanto à prática de actos de co-incineração após o seu trânsito em julgado, é de concluir que o periculum in mora não se verifica também nesta vertente de constituição de uma situação de facto consumado.

\section{CONCLUSÃO}

Conclui-se, assim, que não se verifica um dos requisitos da adopção de providências cautelares conservatórias que é a existência de periculum in mora, em qualquer das suas modalidades, isto é, «fundado receio da constituição de uma situação de facto consumado ou da produção de prejuízos de difícil reparação para os interesses que o requerente visa assegurar no processo principal».

Sendo assim, não pode ser decretada a suspensão de eficácia dos actos suspendendos.

Pelo exposto, o acórdão recorrido tem de ser revogado, na parte em que, concedendo provimento ao recurso jurisdicional interposto da sentença do Tribunal Administrativo e Fiscal de Coimbra, julgou procedente o pedido de suspensão de eficácia dos actos aqui em causa.

Sendo improcedente o pedido de suspenso de eficácia dos actos suspendendos, fica prejudicado, por ser inútil, o conhecimento das outras questões colocadas nos recursos, designadamente a de saber se podiam ser requeridas providências dependendo de duas causas principais e a de saber se a suspensão só se poderia justificar em relação ao acto que concedeu licença de exploração e não também em relação aos actos que concederam licenças de instalação e ambiental.

X. Nos termos e com os fundamentos expostos, acordam em conceder a revista, revogando o acórdão recorrido e fazendo subsistir a sentença do Tribunal Administrativo e Fiscal de Coimbra que julgou improcedente o pedido de suspensão de eficácia dos actos aqui em causa.

Custas pelos Requerentes, neste Supremo Tribunal Administrativo e no Tribunal Central Administrativo Norte, fixando-se em $1 / 7$ das que seriam normalmente devidas (art. $20 .^{\circ},{ }^{\circ}{ }^{3}$, da Lei n. ${ }^{\circ} 83 / 95$, de 31 de Agosto).

Lisboa, 2 de Dezembro de 2009. - José António de Freitas Carvalho (relator) - Alberto Acácio de Sá Costa Reis - Jorge Artur Madeira dos Santos. 


\section{COMENTÁRIO}

\section{Enquadramento}

O Acórdão do Supremo Tribunal Administrativo aqui em anotação constitui um daqueles poucos casos de triplo grau de jurisdição no contencioso administrativo, dado que, no caso concreto, o STA admitiu um recurso de revista que é, por natureza, excepcional e, para mais, no caso de um processo de natureza cautelar com fundamento na relevância social especialmente qualificada da questão - "a incineração como combustíveis para os fornos de fábricas de cimento de certos resíduos tóxicos" - e questões jurídicas relevantes - a aplicação do princípio da precaução em matéria ambiental, entre outras (cfr. Acórdão do STA, de 7.05.2009, que admitiu o recurso).

Neste processo discutia-se o decretamento de uma providência cautelar de suspensão de eficácia dos actos de concessão de licença ambiental, licença de instalação e licença de exploração e, bem assim, da intimação do Ministério do Ambiente, do Ordenamento do Território e do Desenvolvimento Regional (MAOTDR) para a abstenção de concessão de novas licenças para o exercício da actividade de co-incineração de resíduos perigosos e da empresa "CIMPOR" para a abstenção da realização de testes ou demais operações de co-incineração de resíduos perigosos enquanto estivesse suspensa a eficácia das referidas licenças.

Relevante é ainda a circunstância de o processo que culmina com aresto em análise não ter apenas três decisões jurisdicionais mas quatro já que o Acórdão do STA foi objecto de pedido de reforma (cfr. Acórdão do STA de 20.1.2010, mesmo número de processo)․․

Analisemos, então, o Acórdão, focando a nossa atenção no que é central, inovador e, por isso, carente de análise: a inversão do ónus da prova em situações de incerteza científica como consequência da aplicação do princípio da precaução.

\section{0 princípio da precaução e o Acórdão do STA, de 2 de Dezembro de 2009}

O princípio da precaução, enquanto princípio geral de Direito do Ambiente, tem a virtualidade de fornecer a base jurídica para acções antecipadas, ou seja, permite a tomada de acção apesar da ausência de comprovação científica da (i) existência de um risco, da (ii) causa ou do causador concreto do risco ou (iii) quando não seja possível demonstrar a existência de um nexo de causalidade entre o desenvolvimento de determinada actividade (causa hipotética) e a ocorrência de determinados danos ${ }^{2}$. Nestes termos, a abordagem precaucional, tomando em conta a irreversibilidade dos danos ambientais, permite uma salvaguarda dos bens ecológicos pois, quando se duvide do risco ambiental de uma actividade, a aplicação do princípio exige que se tomem as medidas necessárias à evitação da sua concretização, ainda que não ancorado em certezas científicas.

Este princípio, de aplicação generalizada na gestão de riscos ambientais, tem como uma das suas principais implicações a de que, no domínio do ónus da prova (em procedimentos administrativos, ou, para o que ora nos interessa, em processos judiciais), a prova da (não) lesividade para o ambiente de uma determinada actividade cabe a quem a pretenda empreender e não, como é princípio geral de direito, que quem invoca um facto é que tem o ónus de o provar (art. 350.ำ n.. 1 do Código Civil), i.e., o ónus da prova da inocuidade de uma acção em relação ao ambiente é transferido do Estado ou do potencial poluído para o potencial poluidor ${ }^{3}$. É este importante efeito do princípio da precaução que é alvo da

${ }^{1} O$ pedido de reforma da sentença foi indeferido por não se verificarem os requisitos legais para o referido expediente. ${ }^{2}$ Cfr. ANA FREITAS MARTINS, O Princípio da Precaução no Direito do Ambiente, AAFDL, Lisboa, 2002, p. 53. 
atenção do STA que, no entanto, assinala que "a aplicação [do princípio da precaução] aos procedimentos cautelares não pode ter a extensão que o acórdão recorrido lhe dá". Vejamos se é efectivamente assim.

\subsection{O princípio da precaução na doutrina do STA}

A doutrina do acórdão do STA quanto à aplicação do princípio da precaução pode resumirse em quatro vectores fundamentais:

i) o princípio da precaução não tem consagração na Lei Constitucional nem no Tratado da União Europeia e, por isso,

ii) não há "suporte legal para o afirmar como princípio jurídico vigente na nossa ordem jurídica", donde,

iii) deve "antes ser entendido como mera orientação política dos Estados, que o devem ter em conta nas suas opções políticas e legislativas",

iv) daí que, "o invocado princípio não tenha a potencialidade, nem de se sobrepor ao critério jurídico do CPTA no que respeita à verificação dos requisitos do deferimento das providências cautelares, maxime do art. ${ }^{\circ} 120, n .{ }^{\circ} 1, a l . b$ ), nem de inverter a regra do ónus da prova consignada no art. $342 .^{\circ}$ do Código Civil".

Vejamos.

2.2. O princípio da precaução como princípio jurídico positivo: a Constituição, o Direito Comunitário e a Legislação ambiental avulsa

A argumentação do STA, quanto à existência e força jurídica do princípio da precaução, aponta para uma consideração do princípio como mera orientação político-legislativa que, no caso do ordenamento jurídico português, não teria sido sequer adoptada.

Em primeiro lugar e quanto à consagração do princípio da precaução na Constituição da República Portuguesa (“CRP”), a conclusão do STA limita-se a considerar o teor literal do texto constitucional quando, na verdade, a consagração da protecção do ambiente na CRP é feita, desde logo, ao nível das tarefas fundamentais do Estado no art. 9.ำ alínea e) - desde a revisão constitucional de 1982 - e é concretizada pelo art. 66.․․ n.ำ 1 através de uma norma-tarefa que, por um lado, concede um direito ao ambiente $\mathrm{e}^{\mathrm{e}}$, por outro lado, impõe um dever de protecção dos bens ambientais ${ }^{6}$ ao Estado e, concretamente, ao legislador uma imposição legiferante que, dado o carácter dinâmico da protecção do ambiente, implica uma liberdade para conformar os concretos instrumentos jurídicos mobilizáveis e para densificar a imposição constitucional em diferentes formas de protecção7. Já o n.ํㅜ 2 do art. 66.ํ da CRP,

\footnotetext{
${ }_{3}^{3}$ Cfr. ALEXANDRA ARAGÃO, Direito Comunitário do Ambiente, Coimbra, 2002, p. 19.

4 Este ónus estende-se aos efeitos lesivos já devidamente comprovados, aí ao abrigo do princípio da prevenção, cfr. CARLA AMADO GOMES, «Dar o duvidoso pelo (in)certo? Reflexões sobre o "princípio da precaução"», in: Revisto Jurídica do Urbanismo e do Ambiente, n.ำ15/16, Almedina, 2001, p. 16.

5 Para uma análise deste direito subjectivo no plano do direito internacional e constitucional comparado, concluindo pela sua natureza deficitária porque feita à medida da necessidade individual e não da necessidade de reparação ecológica, v. CARLA AMADO GOMES, Risco e modificação do acto autorizativo concretizador de deveres de protecção do ambiente, p. 25 a 149; e sintetizando-o como um direito à abstenção, por parte do Estado e de terceiros, de aç̧ões ambientalmente nocivas, cfr. JOSÉ DE SOUSA CUNHAL SENDIM, Responsabilidade Civil por Danos Ecológicos: Da Reparação do Dano Através de Restauração Natural, Coimbra, 1998, p. 105.

${ }^{6}$ Sobre a fundamentalidade deste dever - pluriforme, composto, heterogéneo e tendencialmente perfeito - ancorado constitucionalmente no princípio da solidariedade (art. 1.ํㅡㅁ da CRP), v. CARLA AMADO GOMES, Risco e Modificação..., cit., p. 151 a 219.

7 Cfr. GOMES CANOTILHO, “O Direito ao ambiente como direito subjectivo”, in: Estudos sobre Direitos Fundamentais, Coimbra, 2004, p. 181.
} 
ao concretizar os meios que devem guiar a prossecução do dever de protecção do ambiente, consagra expressamente, na sua alínea a), a ideia de prevenção, donde, o Estado deve envidar todas as diligências, ancoradas em dados científicos, em ordem a evitar a ocorrência de danos ao bem constitucional que assim se protege. Porque o intérprete não deve distinguir onde o legislador não distingue, a questão interpretativa que fica então em aberto é se essa protecção também deve ser acautelada caso não existam certezas científicas, isto é, incluirão as normas-tarefa ecológicas uma precaução contra os riscos?

Nesta tarefa interpretativa é mister convocar os restantes e inúmeros valores constitucionalmente protegidos que exigem a utilização dos recursos naturais ${ }^{8}$ que, conjugados com a protecção ambiental, resultam numa lógica, também de categoria constitucional (art. 66.․ㅡ, ก. ${ }^{-} 2$ ), de desenvolvimento sustentável. No entanto, esta livre ponderação dos valores constitucionalmente protegidos feita, naturalmente, ao abrigo do princípio da proporcionalidade (art. 18. da CRP) encontra forte limitação em face da dimensão de irreversibilidade que podem ter certos danos ambientais, hipotecando-se, assim, a solidariedade intergeracional, o que poderá justificar o efectivo sacrifício de outros bens constitucionalmente protegidos ${ }^{\text {. }}$

A questão a colocar - que o STA, por não entrar no caminho interpretativo que vimos empreendendo, não pondera sequer - reconduz-se, assim, a saber se essa ponderação exige e, bem assim, admite o sacrifício de bens constitucionalmente protegidos com base em incerteza científica. Deste ligeiro caminho interpretativo que empreendemos parece resultar que a protecção constitucional ampla do bem ambiente admite, a um tempo, o sacrifício, as mais das vezes temporário, de outros valores, nomeadamente de índole económica e, a outro tempo, exige, em nome de um nível de protecção elevado, a permanência do bem jurídico a proteger, isto é, a protecção constitucional só será efectiva se não for privada do seu objecto. Neste âmbito, o princípio da precaução funciona como garantia material de realização efectiva do Princípio do Nível Elevado de Protecção Ecológica ${ }^{10}$, pois a obrigação (imposta constitucionalmente) de proteger o ambiente de forma elevada só será cumprida se esta não for privada do seu objecto antes do seu cumprimento, isto é, o princípio da precaução serve para obviar ao risco de, pela delonga dos processos decisórios (administrativos ou jurisdicionais), termos excelentes decisões para a protecção do ambiente (em abstracto), mas decisões meramente platónicas (em concreto), pois os fins práticos que acautelavam já não serão atingíveis, o que não é mais que a verificação da existência do perigo na demora da protecção dos bens ecológicos. Em segundo lugar e quanto à consagração do princípio da precaução no Tratado da União Europeia, o STA acerta na falta de consagração do princípio no Tratado da União Europeia mas olvida a sua consagração expressa no n.ำ 2, art. $174 . \stackrel{\circ}{\text { do }}$ Tratado que Institui a Comunidade Europeia ${ }^{11}$, indicando expressamente que a política da comunidade "basear-se-á” nesse princípio. O acervo do Direito Comunitário no domínio do princípio da precaução, para além de consagrações no Direito Comunitário derivado, conta com a Comunicação da Comissão relativa ao Princípio da Precaução, de Fevereiro de $2000^{12}$,

\footnotetext{
${ }_{8}$ Para um elenco dos valores e normas constitucionais pertinentes e uma tese da sua harmonização em sede de aplicação do princípio da precaução, concluindo pela sua actuação em ultima ratio, v. CARLA AMADO GOMES, A Prevenção à Prova no Direito do Ambiente: em especial os actos autorizativos ambientais, Coimbra Editora, Coimbra, 2000, p. 44 a 52.

9 Em sentido semelhante, embora circunscrevendo-o aos casos em que há uma segura probabilidade do dano, cfr. CARLA AMADO GOMES, A Prevenção..., cit., p. 49.

${ }^{10}$ Cfr. AleXANDRA ARAGÃO, O Princípio do Nível Elevado de Proteç̧ão Ecológica, Almedina, Coimbra, 2006, p. 265 a 300 e p. 787 a 790.

${ }^{11} \mathrm{~A}$ denominação deste Tratado foi alterada, através do Tratado de Lisboa, para "Tratado sobre o Funcionamento da União Europeia” e, com Tratado de Lisboa, o referido art. 174.ำ foi renumerado passando a ser, agora, o art. 191.․․ ${ }_{12}$ Trata-se da comunicação da Comissão COM (2000)1 final, de 2 de Fevereiro.
} 
que veio responder a uma necessidade ${ }^{13}$ de harmonização e racionalização na sua aplicação na política comunitária e, também, nas políticas dos diversos Estados-Membros.

Em último lugar, cumpre referir que o ordenamento jurídico português consagra, em legislação ambiental avulsa, diversos exemplos de uma abordagem precaucional ${ }^{14}$, e até do próprio princípio qua tale, como na Lei da Água (Lei n.ำ 58/2006, de 29 de Dezembro)

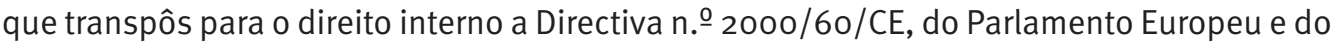
Conselho, de 23 de Outubro, e introduziu no direito interno português a primeira definição do princípio da precaução no art. $3^{\circ}$, n. $\stackrel{0}{1}$, alínea e), nos seguintes termos:

\section{"Princípio da precaução, nos termos do qual as medidas destinadas a evitar o impacte negativo de uma acção sobre o ambiente devem ser adoptadas, mesmo na ausência de certeza científica da existência de uma relação causa-efeito entre eles."}

\subsection{O princípio da precaução como princípio jurídico positivo ou orientação política?}

Infirmada a tese da não consagração do princípio da precaução no ordenamento jurídico português, cumpre verificar se se trata de um princípio jurídico ou, pelo contrário e como refere o STA, de uma "mera orientação política dos Estados, que o devem ter em conta nas suas opções políticas e legislativas".

A força vinculativa dos princípios de Direito do Ambiente é idêntica à de qualquer outro princípio jurídico, ou seja, não é por terem uma natureza principial que deixam de ter juridicidade para passarem a ter uma mera vinculatividade política, pois a circunstância de terem um nível de abstracção jurídica elevada não implica que sejam meras directivas políticas, pelo contrário, apenas significa que são naturalmente elásticos e passíveis de concretizações normativas várias ${ }^{15}$. Por isso, para além da precipitada conclusão sobre a vigência do princípio no ordenamento jurídico português, o STA incorreu aqui numa apreciação que encontra pouco fundamento nos textos legais que, para além de consagrarem o princípio expressamente, estabelecem, outras tantas vezes, mecanismos de gestão de riscos apoiados em abordagens precaucionais ${ }^{16}$ e, por isso, claramente densificadoras daquele princípio que, assim, não se queda na mera orientação e vinculatividade políticas, mas é verdadeiro princípio jurídico operativo.

\footnotetext{
${ }_{13}^{13}$ Dando conta desta necessidade, a par de outra de aproximação legislativa entre os Estados-membros, cf. PHILIPPE ICARD, «L'articulation de l'Orde Juridique Communautaire et dês Ordres Nationaux dans l'application du Principe du Précaution», Revue Juridique de l'Environment: Le Principe de Précaution, número especial/2000, p. 48 a 54. ${ }^{14}$ Os exemplos são vários: o Decreto-Lei n. ${ }^{-52 / 85}$, de 1 de Março (que regula a Zona Económica Exclusiva), prevê, no seu art. $10 . \stackrel{\circ}{,}$ n. $\stackrel{\circ}{3}$, que, para o efeito da fixação de máximos de captura se devem tomar em conta, a título de precaução, dados insuficientes ou de diminuta confiança; o Decreto-Lei nํ194/2000, de 21 de Agosto, que regula

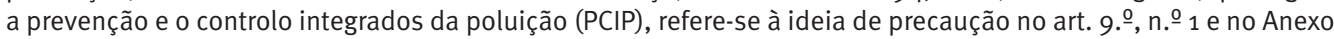
IV; o Decreto-Lei nำ 72/2003, de 10 de Abril, que regula a libertação deliberada no ambiente de organismos geneticamente modificados, refere no seu preâmbulo a consideração do princípio da precaução no diploma e o art. 1.0 refere a conformidade do regime com o princípio da precaução; o Decreto-Lei no 69/2000, de 3 de Maio, alterado pelo Decreto-Lei n. ${ }^{0}$ 197/2005, de 8 de Novembro, que aprova o regime jurídico da avaliação de impacte ambiental ("AIA"), no seu Anexo III - que estabelece o conteúdo mínimo do Estudo de Impacte Ambiental ("ElA") e concretiza o art. $2^{-}$, alínea i) -, exige, no seu n. ${ }^{\circ}$, a descrição e hierarquização dos impactes ambientais significativos que inclui a análise dos efeitos directos e indirectos, secundários e cumulativos, a curto, médio e longo prazos, permanentes e temporários, positivos e negativos, e no n.ำ 9 do mesmo Anexo III exige-se o resumo das eventuais dificuldades, incluindo lacunas técnicas ou de conhecimentos, encontradas na compilação das informações requeridas, tudo o que vem indicar que o EIA deve contemplar uma abordagem apoiada no princípio da precaução, porquanto se requer não só uma análise exaustiva dos impactes ambientais, incluindo os potenciais como, e mais importante, se exige o resumo das lacunas técnicas e científicas, ou seja, da incerteza subjacente aos dados constantes do EIA que será, assim, incluída no processo de decisão tendente à declaração de impacte ambiental.

${ }^{15}$ Neste sentido, cfr. ANA FREITAS MARTINS, O Princípio da Precaução..., cit., p. 47, e dando conta das posições doutrinárias sobre o tema, cfr. ALEXANDRA ARAGÃO, O Princípio do Poluidor Pagador: pedra angular da política comunitária do ambiente, Coimbra Editora, Coimbra, 1997, p. 74 e 75.

${ }^{16} \mathrm{~V}$., a título de exemplo, o referido na nota 13.
} 


\section{0 princípio da precaução: 0 (sub)princípio in dubio pro ambiente e a inversão do ónus da prova}

Estabelecida a vigência e operatividade, no ordenamento jurídico português, do princípio da precaução em matéria ambiental, vejamos se, existindo enquanto princípio jurídico positivo, pode "sobrepor[-se] ao critério jurídico do CPTA no que respeita à verificação dos requisitos do deferimento das providências cautelares, maxime do art. $\left.{ }^{\circ} 120, n .{ }^{\circ} 1, a l . b\right)$ " ou, mesmo, "inverter a regra do ónus da prova consignada no art. 342. ${ }^{\circ}$ do Código Civil".

\subsection{In dubio pro ambiente?}

O STA entende que o princípio da precaução não tem, por força da sua natureza de mera orientação política, a potencialidade para se sobrepor aos requisitos de que dependem a concessão de providências cautelares (no caso, providência cautelar conservatória) previstos no art. $120 . \stackrel{\circ}{,}$ n. $\stackrel{-}{1}$, alínea b), do CPTA. No entanto, mesmo que se aceite, quanto ao princípio da precaução, a natureza de princípio jurídico operativo, não nos parece que ele se sobreponha necessariamente ao juízo sobre a verificação desses requisitos, mas antes operará, na sua dimensão de princípio regulativo (ou seja, na veste de in dubio pro ambiente) na ponderação daqueles mesmos requisitos de que depende a concessão da providência.

Ao considerar a verificação daqueles requisitos, a análise a fazer pelo juiz cautelar terá, numa lógica precaucional, de ter em vista a preservação dos bens ecológicos (rectius: 0 periculum in mora ou a constituição de facto consumado contrária à preservação dos bens ecológicos), pois aquela preservação, em obediência ao claro comando constitucional do art. 66. - , n. .1 da CRP, reclama, por força da irreversibilidade dos putativos danos, uma protecção majorada em face de outros interesses, protecção que, nesta sede, é dada por este tratamento de favor a ser dispensado aos bens constitucionalmente protegidos.

Esta valoração in dubio pro ambiente dar-se-á em casos de (i) ponderação de diferentes bens em confronto com bens ecológicos ou (ii) quando houver a possibilidade de erro quanto ao prognóstico de danos ambientais, podendo estabelecer-se mesmo presunções legais de cautela, fazendo recair o risco do erro na sobreprotecção em vez da subestimação de riscos ${ }^{17}$ e (iii) mesmo no caso de existirem duas prognoses de sentido diferente (uma favorável a tomada de medidas e outra desfavorável) por via do diferente lapso temporal em que projectam a análise, deve haver prioridade da prognose negativa sobre a positiva por força do in dubio pro ambiente, mesmo que isso signifique desconsiderar uma prognose favorável na análise de curto prazo ${ }^{18}$.

Deste modo, o princípio da precaução na sua dimensão de princípio regulativo in dubio pro ambiente reclama, na ponderação jurisdicional relativa à protecção de bens ecológicos, a adopção de um critério de prova mais maleável na verificação dos requisitos legais (no caso concreto, dos requisitos de que depende a concessão de uma providência conservatória), pois um critério beyond a reasonable doubt, próprio do processo penal nos países de common law ao exigir um elevado nível de certeza, debate-se com os especiais problemas de incerteza quanto aos riscos, a causalidade e, mesmo, a existência de dano. CHARMIAN BARTON propõe um critério de reasonable ecological or medical concern ${ }^{19}$, ou seja, terá que ficar demonstrada a inexistência de motivos que sustentem uma preocupação ecológica razoável; o mesmo Autor não deixa de notar a subjectividade associada a um tal critério, mas só assim se encontra a flexibilidade na análise do risco que se exige num tempo de mo-

\footnotetext{
${ }_{17}$ Cfr. ANA FREITAS MARTINS, O Princípio da Precaução..., cit., p. 56.

${ }^{18} \mathrm{Cfr}$. CARLA AMADO GOMES, A Prevenção..., cit., p. 36 e 37.

${ }^{19}$ Cf. CHARMIAN BARTON, «The Status of the precautionary principle in Australia: its emergence in legislation and as a common law doctrine», in: The Harvard Environmental Law Review, n. ํ 2, vol. 22, 1998, p. 549 e ss.
} 
dernização ecológica do direito e permitindo, daquela forma, introduzir um "teste do homem médio". Esta proposta, que pode parecer simples e até simplista introduz um vector de bom senso em situações em que os dados científicos são contraditórios e, por isso, o juiz não pode procurar resposta para a formação da sua convicção para a decisão da causa na prova pericial, pois os dados que aí encontrará serão, por força da incerteza científica, contraditórios.

Um critério de prova de dúvida ecológica razoável, motivada pela aplicação do princípio regulativo in dubio pro ambiente, introduz flexibilidade na análise da prova que, ao mesmo tempo que não é despicienda, não é violenta. De facto, aquela flexibilidade implica que se desassocie, em definitivo, a aplicação do princípio da precaução da imposição de patamares de risco zero ${ }^{20}$ e, simultaneamente, acautela devidamente a abordagem precaucional aos riscos existentes num juízo razoável e racional sobre as posições em confronto formando (ou não) uma reasonable ecological concern. Com a demonstração da existência de uma preocupação ecológica arrazoada possibilita-se um critério na aferição de prova que expressará, se correctamente interpretado, uma prossecução do interesse público de protecção ambiental de forma correcta e proporcional e, do mesmo modo, proporcionará ao julgador um arrimo sólido em situações de incerteza e contraditoriedade dos dados científicos ou periciais disponíveis.

Assim, no caso concreto, em sede de verificação dos requisitos de que depende a concessão de providências - verificação do periculum in mora ou da criação de uma situação de facto consumado - , deveria ser considerado o vector de preservação dos bens ecológicos de uma forma majorada ainda que não tendenciosa, ou seja, a consideração da protecção deste interesse público com dignidade constitucional deve ser ponderada na devida conta aquando da verificação daqueles requisitos. Donde, adentro a análise da prova relativa aos mencionados requisitos, o juiz deverá valorar in dubio pro ambiente quaisquer dúvidas que se levantem na verificação dos requisitos formando, a esse propósito, um juízo sobre a existência de uma dúvida ecológica razoável, o que, no caso concreto, em face da notória e pública incerteza (e discussão) científica em torno do processo de co-incineração e dos seus efeitos no ambiente e, reflexamente, na saúde das populações, haveria de significar o preenchimento daqueles requisitos e o consequente decretamento da providência.

Com esta dimensão e este alcance, o princípio regulativo do in dubio pro ambiente não introduz qualquer desequilíbrio no balancing process do art. 120.ํ, n. .9 do CPTA ${ }^{21}$. De facto, o âmbito de actuação que recortamos para este subprincípio regulador favorável à protecção dos bens ecológicos situa-se na verificação dos requisitos previstos para a concessão da providência [art. 120.ํ, n.ำ 1, alíneas a) e b) do CPTA] e não em sede daquela ponderação. Todavia, admitindo um caso em que o projecto de adopção de uma providência, verificados os requisitos de que depende a sua adopção, fosse recusada com base da ponderação dos interesses, prevista no $\mathrm{n} .-2$ do art. $120 .$. do CPTA, num sentido pro ambiente não desequilibraria a dita ponderação, pois este tipo de favor ambiental já se encontra implícito nos concretos bens jurídicos ecológicos dignos daquela especial protecção. Ou seja, o in dubio pro ambiente é um princípio regulativo que incide sobre bens jurídicos constitucionalmente protegidos e cuja irreparabilidade deve ser ponderada com auxílio naquela regulação mais favorável mas nem assim tendenciosa e, por essas razões, não desequilibra a válvula de escape da tutela cautelar que é ponderação de interesses do art. 120.ำ n.ํํㅡ 2 do CPTA.

\footnotetext{
${ }^{20}$ Como defende quem, alegando a deriva securitária inerente ao princípio da precaução, entende que o risco que este princípio concede é apenas o risco zero.

${ }^{21}$ No sentido contrário, v. CARLA AMADO GOMES, «And now something completely different: a co-incineração nas malhas da precaução», in: Cadernos de Justiça Administrativa, n 63, Maio/Junho 2007, p. 55 a 59.
} 


\subsection{Inversão do ónus da prova}

O STA considera que o princípio da precaução não tem a virtualidade de inverter o ónus da prova estabelecido, em termos gerais, no art. 350.ำ n. $\stackrel{1}{1}$ do Código Civil. Alguma doutrina, em anotação a Acórdão do TCA-Norte, relacionada com este mesmo "processo de co-incineração" e citada, aliás, pelo Acórdão em análise, também já censurou a “intenção justiceira do julgador que aceitou uma auto-geração da dúvida sobre a perigosidade do processo" que, ali, inverteu o ónus da prova, notando que tal inversão viola o direito ao processo equitativo (consagrado no art. 20. $\stackrel{\circ}{\text {, n. }} \stackrel{\circ}{4}$ da CRP e, também, no art. 6.ํ da Convenção Europeia dos Direitos do Homem) ${ }^{22}$. Vejamos.

A inversão do ónus da prova, longe de constituir uma violência para o potencial poluidor, é uma decorrência natural da lógica precaucional de “in dubio pro ambiente” pois, a preservação dos bens ecológicos reclama, por força da irreversibilidade dos putativos danos, uma protecção majorada em face de outros interesses, protecção essa, que em sede ónus da prova nos leva a inverter esse ónus assegurando não mais que um equilíbrio de facto entre as partes ${ }^{23}$, pois a prova deixa de incumbir a quem por atribuição legal (caso de entes administrativos) ou em defesa dos seus interesses ou fim associativo (caso dos particulares e associações de defesa de bens ecológicos) assume a preservação dos bens ecológicos em situações de incerteza quanto aos riscos envolvidos em determinada actividade. Esta restrição pode ser entendida, sem que se conceda nisso, como uma restrição à liberdade de iniciativa económica, mas, ainda nesse caso, sempre passará no teste de proporcionali-


protecção de bens jurídicos constitucionalmente protegidos - o direito ao ambiente ${ }^{24}$ (cfr. art. 66. $\stackrel{\circ}{ }, \mathrm{n} . \stackrel{\circ}{1} 1$ da (RP).

Por outro lado, o entendimento razoável (i.e., não securitário) do princípio da precaução exige que, com a inversão do ónus da prova, não se fomente uma indesejável diabolica probatio e uma justiça tendenciosa. Assim, este ónus deve ser selectivo, id est, em função das dúvidas existentes quanto aos riscos ambientais assim se deverá modelar o ónus da prova podendo oscilar entre a inversão total ou ser aligeirado por força dos riscos identificados e da capacidade técnica para provar a sua (não) inocuidade; só desta forma será também possível que, na conformidade com a CRP, tal efeito não resulte na violação do núcleo essencial do direito de iniciativa económica (art. 18.ํㅜ n. $\stackrel{0}{3}$ da CRP). Ou seja, tal como apontámos em relação à ponderação in dubio pro ambiente, também em relação à inversão do ónus da prova, o princípio da precaução permite que o juiz introduza bom senso no acometimento do ónus da prova, atendendo às circunstâncias do caso concreto, nomeadamente, a quem está em melhor situação de comprovar a inexistência de riscos relevantes.

Ainda a respeito da "violência" que representa a inversão do ónus da prova, a verdade é que este efeito, ao nível processual, não determina a decisão jurisdicional. Com efeito, inverter o ónus da prova significa apenas que, nessa hipótese, passa a ser quem tem interesse no desenvolvimento de uma determinada actividade - no caso concreto, o MAOTDR e a empresa "Cimpor" - que tem que carrear para o processo elementos que provem a existência de riscos a um nível aceitável, e assim, contribuindo para a redução da incerteza científica ${ }^{25}$.

\footnotetext{
${ }^{22}$ Cfr. idem, p. 58 e 59.

${ }^{23}$ Cf. CARLA AMADO GOMES, A Prevenção..., cit., p. 35 a 38.

24 Para uma análise deste direito subjectivo, v. CARLA AMADO GOMES Risco e..., cit., p.25 a 149; e sintetizando-o como um direito à abstenção, por parte do Estado e de terceiros, de aç̧ões ambientalmente nocivas, cfr. JOSÉ DE SOUSA CUNHAL SENDIM, Responsabilidade Civil..., cit., p. 105.

${ }^{25} \mathrm{Na}$ actividade administrativa - nomeadamente na concessão de actos autorizativos - é corrente que quem se propõe a realizar determinada actividade tenha o ónus de estabelecer a "segurança" da actividade a realizar; dando conta de regulamentação neste sentido, nos Estados Unidos da América, cf. DANIEL BODANSKY et alli, «The precautionary principle in U.S Environmental Law», in: Interpreting the..., cit., p. 210 a 213.
} 
Portanto, apenas no caso de não ser possível provar a existência de riscos num nível aceitável a inversão do ónus da prova funcionará contra quem o tinha, ou seja, apenas no caso de existirem, efectivamente, riscos sérios, a decisão jurisdicional será desfavorável a quem tinha o ónus da prova (invertido) e, nesse caso, não haverá violência na decisão negativa para esses interesses mas corresponderá ao preço a pagar pelo direito ao ambiente garantido constitucionalmente.

A inversão do ónus da prova nos termos que delineámos encontra excelente campo de aplicação nos processos cautelares, nomeadamente em processo na jurisdição administrativa, pois, instrumentais que são de um processo principal e marcados que estão pela necessidade de um conhecimento sumário (sumaria cognitio), não podem deixar de colher, entre os efeitos processuais do princípio da precaução, relevante apoio jurídico ao socorrem-se do princípio in dubio pro ambiente ou, mesmo, de uma inversão do ónus da prova selectiva para a consideração dos requisitos de que dependem a concessão das providências cautelares.

Dir-se-á, contra o que aqui avançamos, que uma abordagem precaucional como a proposta introduz insegurança jurídica ou mesmo que representa uma deriva securitária tendente à erradicação dos riscos ambientais. No entanto, esta abordagem precaucional, aplicada que fosse e sustentada jurídico-dogmaticamente que teria que ser, pela jurisprudência nacional, não traria mais insegurança jurídica que a prossecução dos valores da Justiça consente pois, adentro uma verdadeira justiça ambiental, a preservação dos bens ecológicos exige, em nome da irreversibilidade dos danos, que o tratamento de favor dispensado àqueles bens seja não só um efeito jurídico reconhecido como, para além de corrente doutrinal, seja uma orientação jurisprudencial sólida a ser adoptada pelos nossos tribunais superiores incluindo, evidentemente, o STA.

Em conclusão, a inversão do ónus da prova permite (como permitiu na decisão do TCA-Norte) que, havendo dados científicos díspares e, portanto, incerteza científica quanto aos riscos, o juiz estabeleça a sua conviç̧ão com base na probabilidade de ocorrência dos riscos identificados ponderando, assim, devidamente, a incerteza nos dados científicos e fazendo recair o ónus da prova, de forma selectiva, sobre quem tem o interesse em desenvolver determinada actividade e, por isso e pelo conhecimento que detém quanto a essa actividade, deve provar a existência de um risco aceitável quanto à prossecução de determinada actividade. De modo que, ao contrário do que é sugerido por vezes, nem a inversão do ónus da prova é um questão de "tudo ou nada" - a inversão pode ser selectiva e razoável - nem é uma violência - porque (i) é motivada pela preservação dos bens ecológicos e, mais ainda, (ii) não determina a decisão substantiva sobre qualquer pleito, na medida em, se os riscos forem convenientemente afastados por demonstrações científicas, a prova fica feita e não há necessidade de qualquer abordagem precaucional a tomar pelo juiz.

\section{0 princípio da precaução e a tutela cautelar: tempus fugit}

O tempo é um factor de inegável e, tantas vezes, de inexorável importância na matéria da protecção ecológica e, por isso, é também inegável o conforto que a ideia de cautela - proporcionada pelo princípio da precaução - traz a esta matéria, pois o espectro da irreversibilidade que paira sobre decisões com implicações para o ambiente exige uma abordagem cautelar - 0 que não é o mesmo que apelar ao imobilismo, como quando falamos de precaução quanto a riscos não se pretende estabelecer patamares de risco zero.

Numa sociedade de risco, o controlo jurisdicional da actividade administrativa deve atender, portanto, aos vectores do que já é um fenómeno reconhecido na própria actividade administrativa: a cautelarização com a consequente incorporação dos requisitos de urgência 
e precaução como elementos verdadeiramente constitutivos do interesse público ${ }^{26}$. Tal como na actividade administrativa, o controlo jurisdicional em situações de risco não tem o tempo normal do processo na jurisdição administrativa mas é, antes, modelado pela urgência que caracteriza as situações de risco neste tempo que, repetimos, é de uma sociedade de risco defender o contrário, que o tempo da decisão jurisdicional está a coberto de uma redoma imperturbável, é condenar o direito fundamental à tutela jurisdicional efectiva e, de modo particular, a protecção jurisdicional dos bens ecológicos.

A este tempus fugit na tutela de situações de risco, mormente ambiental, o princípio da precaução responde com a sua abordagem precaucional que, partindo da incerteza científica quanto a situações de risco, afirma a "primariedade do ambiente sobre outros bens jurídicos [nomedamente através da valoração in dubio pro ambiente ou da inversão do ónus da prova selectiva], cuja protecção deve ser procurada em primeira mão ao nível dos processos urgentes - principais e cautelares - porque só estes tutelam antecipadamente um bem jurídico por natureza irressarcivel e infungivel"27.

É assim que o recurso à tutela cautelar se revela de enorme importância na protecção dos bens ecológicos ${ }^{28} \mathrm{e}$ o princípio da precaução, neste âmbito de actuação jurisdicional, pode fornecer arrimos para decisões favoráveis a essa protecção ao (i) informar o processo com a ideia de cautela que deve imperar em todas as decisões susceptíveis de por em causa os bens ecológicos tendo como horizonte a difícil (quando não impossível) restauração ecológica ${ }^{29}$, (ii) ao operar a inversão do ónus da prova colocando-o a cargo do potencial poluidor e ao (iii) introduzir como princípio regulativo da tomada de decisões o in dubio pro ambiente e, assim, constituindo o bem jurídico ambiente como valor prevalecente em caso de dúvida.

Tudo o que contribui para que se exigisse mais da jurisprudência do STA neste tempo já maduro para que os tribunais administrativos introduzam, no contencioso ambiental (e, para mais, no contencioso cautelar ambiental), o princípio da precaução, num caminho que a jurisprudência comunitária já trilhou, o TCA-Norte teve o ensejo de trilhar, mas que o STA não acompanhou...ainda não terá chegado o tempo de um leading case na jurisprudência portuguesa que, a propósito da aplicação do princípio da precaução, reflicta a necessidade de uma nova era para a justiça cautelar "amiga do ambiente".

Pedro Matias Pereira

Mestrando em Direito Administrativo

da Faculdade de Direito da Universidade de Coimbra,

Advogado

\footnotetext{
${ }^{26}$ A expressão e a análise é de LUÍS FILIPE COLAÇO ANTUNES, Direito Público do Ambiente (Diagnose e Prognose da Tutela Processual da Paisagem), Almedina, Coimbra, 2008, p. 121.

${ }^{27}$ Cfr. LUÍS FILIPE COLAÇO ANTUNES, Direito Público do Ambiente ..., cit., p. 165 e ss. que analisa como a tutela do direito ao ambiente através do princípio da precaução tem implicações quanto aos prazos de impugnação, à legitimidade na acção popular e mesmo na convolação do processo cautelar em processo principal.

${ }^{28}$ Para uma análise no mesmo sentido, v. Carla AMADO GOMES, A Prevenção..., cit., p. 90 a 94.

${ }^{29}$ Sobre este modo de reparação do prejuízo ecológico e a sua alternativa - compensação ecológica - v. JOSÉ DE SOUSA CUNHAL SENDIM, Responsabilidade Civil ..., cit., p.125 e ss..
} 